Nevada

Environmental

Restoration

Project

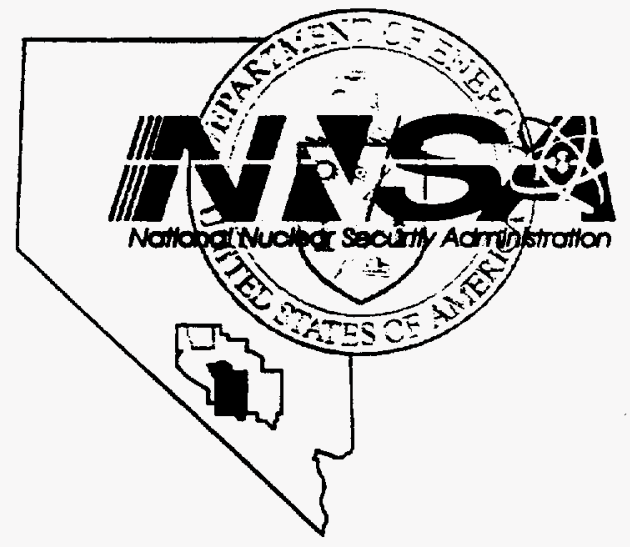

Closure Report for

Corrective Action Unit 110:

Areas 3 RWMS

U-3ax/bl Disposal Unit

Nevada Test Site, Nevada

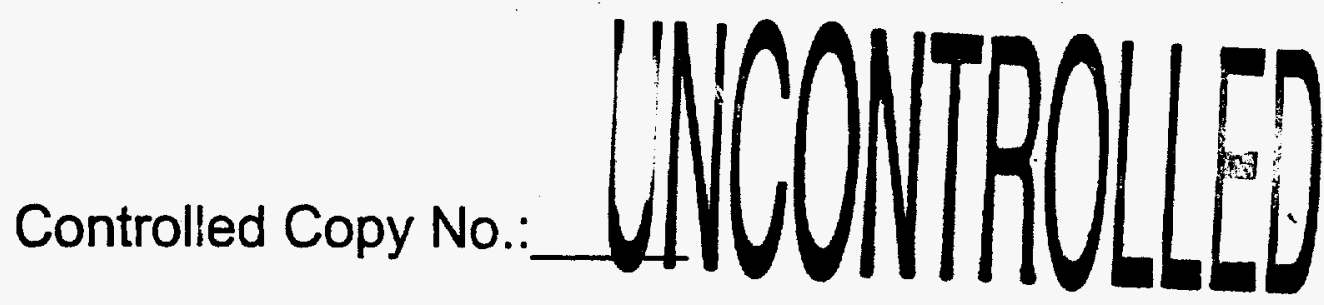

Revision: 1

August 2001

Environmental Restoration

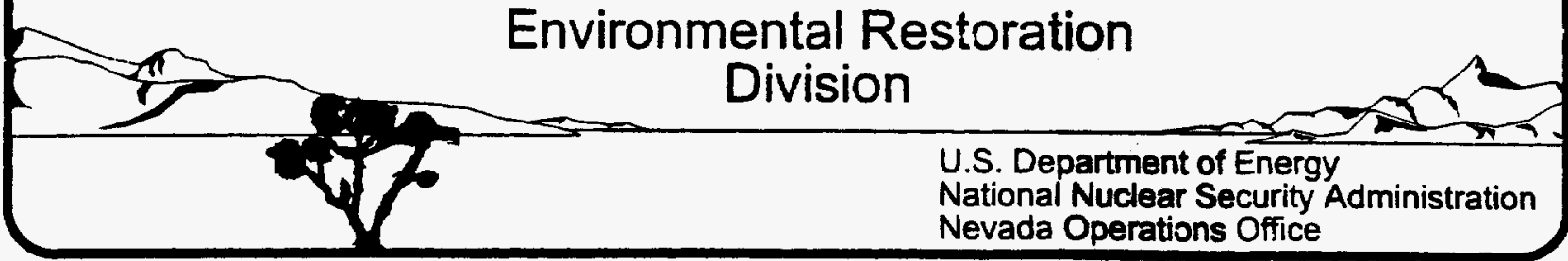


Available for sale to the public, in paper, from:

U.S. Department of Commerce

National Technical Information Service

5285 Port Royal Road

Springfield, VA 22161-0002

Telephone: (800) 553-6847

Fax: (703) 605-6900

E-mail: orders@ntis.fedworld.gov

Online ordering: http://www.ntis.gov/ordering.htm

Available electronically at htto://www.doe.gov/bridge

Available for a processing fee to the U.S. Department of Energy and its contractors, in paper, from:

U.S. Department of Energy

Office of Scientific and Technical Information

P.O. Box 62

Oak Ridge, TN 37831-0062

Telephone: (865) 576-8401

Fax: (865) 576-5728

E-mail: reports@adonis.osti.gov

Reference herein to any specific commercial product, process, or service by trade name, trademark, manufacturer, or otherwise, does not necessarily constitute or imply its endorsement, recommendation, or favoring by the U.S. Government or any agency thereof or its contractors or subcontractors. 


\title{
CLOSURE REPORT FOR CORRECTIVE ACTION UNIT 110: AREA 3 RWMS U-3ax/bl DISPOSAL SITE NEVADA TEST SITE, NEVADA
}

\author{
Prepared for the \\ U. S. Department of Energy \\ National Nuclear Security Administration \\ Nevada Operations Office \\ Work Performed Under Contract No. DE-AC08-96NV11718
}

Controlled Copy No.:

Revision: 1

August 2001 
-

$\mathbf{a}$

$\mathbf{m}$

a

.

-

-

THIS PAGE INTENTIONALLY LEFT BLANK

- 
DOE/NV-733

\section{CLOSURE REPORT FOR CORRECTIVE ACTION UNIT 110: AREA 3 RWMS U-3ax/bl DISPOSAL SITE NEVADA TEST SITE, NEVADA \\ Revision 1}

Approved by:

Janet L. Appenzeller-Wing, Project Manager Industrial Sites Project
Date: $8-9-01$

\footnotetext{
Approved by: Rolern OM. Bangestes fh. Date: $8 / 10 / 01$ Nevada Environmental Restoration Project
} 
Closure Repon - CAU 110

Section: Table of Contents

\section{TABLE OF CONTENTS}

ACRONYMS AND ABBREVIATIONS $\ldots \ldots \ldots \ldots \ldots \ldots \ldots \ldots \ldots \ldots$ vii

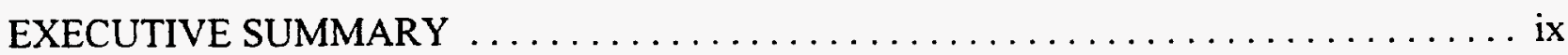

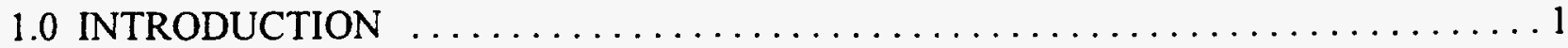

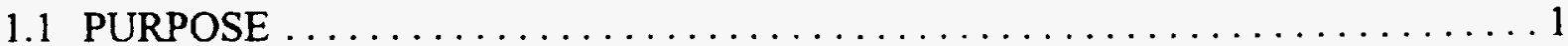

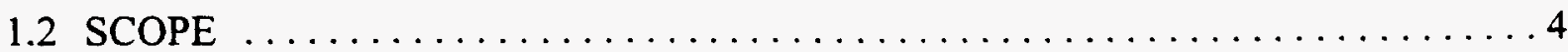

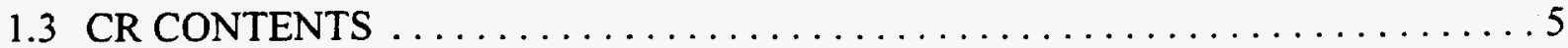

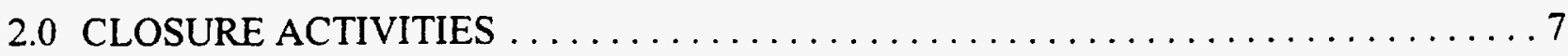

2.1 DESCRIPTION OF CORRECTIVE ACTION ACTIVITIES $\ldots \ldots \ldots \ldots \ldots \ldots 7$

2.1.1 Installation of Time-Domain Reflectometry Instrumentation Nests . . . . . . 7 7

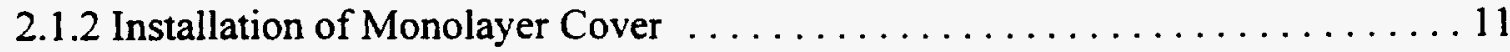

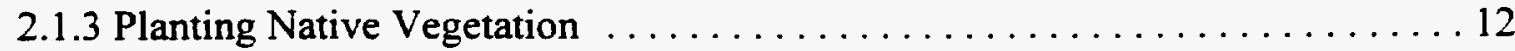

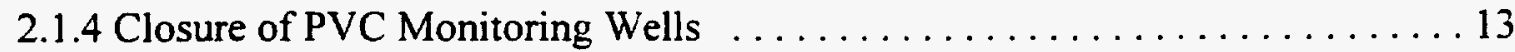

2.1.5 Installation of Monolayer Cover Fence $\ldots \ldots \ldots \ldots \ldots \ldots \ldots \ldots \ldots \ldots \ldots \ldots$

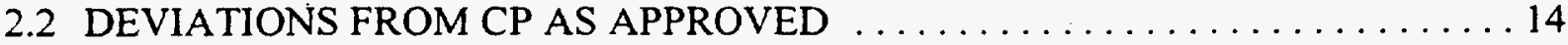

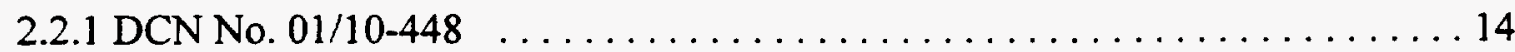

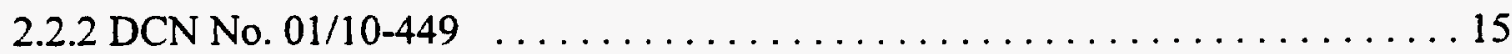

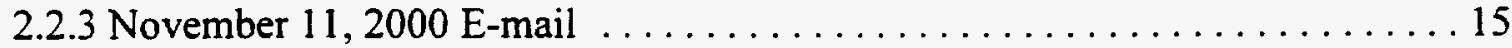

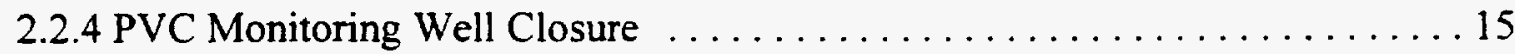

2.3 CAU 110 CLOSURE ACTIVITY SCHEDULE $\ldots \ldots \ldots \ldots \ldots \ldots \ldots \ldots \ldots \ldots \ldots \ldots \ldots$

2.4 CAU 110 FINAL SURVEY "AS BUILT" DRAWINGS $\ldots \ldots \ldots \ldots \ldots \ldots \ldots$

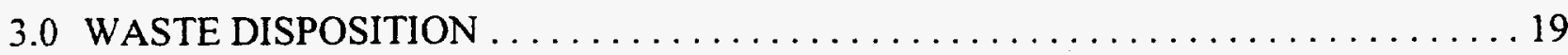

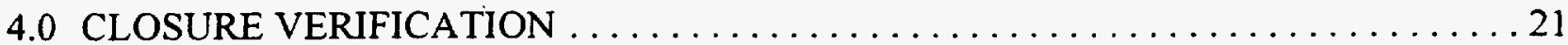

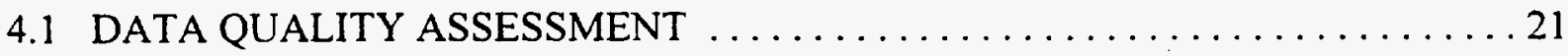

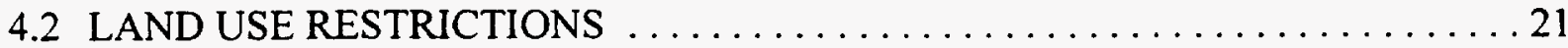

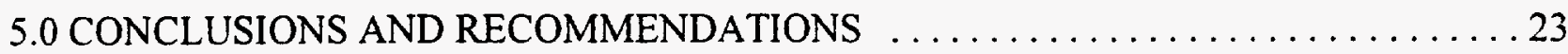

5.1 POST-CLOSURE MONITORING REQUIREMENTS $\ldots \ldots \ldots \ldots \ldots \ldots \ldots \ldots \ldots \ldots$

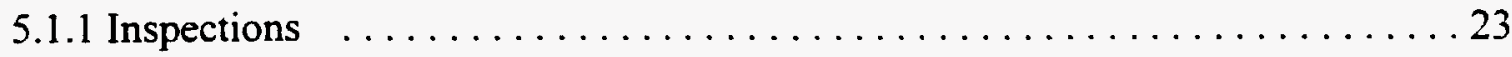

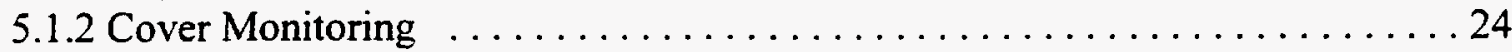

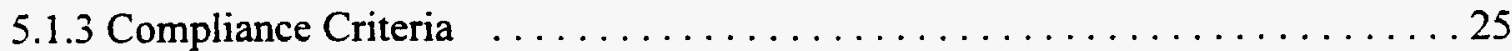

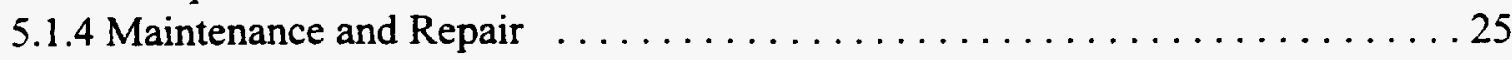




\section{TABLE OF CONTENTS (Continued)}

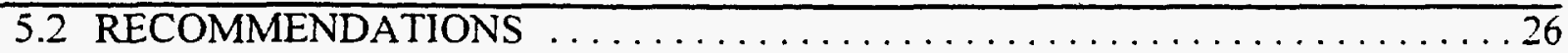

6.0 REFERENCES

APPENDIX A - CERTIFICATION OF CLOSURE

APPENDIX B - APPROVAL MATRIX AND CHECKLIST

APPENDIX C - TESTING/INSPECTION REPORTS

APPENDIX D - VEGETATION SPECIES LIST

APPENDIX E - DEVIATIONS FROM CONSTRUCTION QAP

APPENDIX F - “AS-BUILT” DRAWINGS FOR THE AREA 3 U-3AX/BL COVER

APPENDIX G - LAND-USE RESTRICTIONS

APPENDIX H - PHOTOGRAPHS AND FIELD NOTES

APPENDIX I - U-3ax/bl TDR CALIBRATION

APPENDIX J - NDEP COMMENT RESOLUTION

DISTRIBUTION LIST

\section{FIGURES}

FIGURE 1 - CAU 110 SITE LOCATION MAP $\ldots \ldots \ldots \ldots \ldots \ldots \ldots \ldots \ldots \ldots \ldots \ldots \ldots \ldots \ldots$

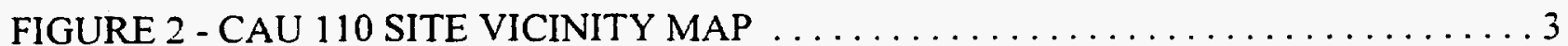

FIGURE 3 - PLAN VIEW OF TDR NESTS AND TRENCHES $\ldots \ldots \ldots \ldots \ldots \ldots \ldots$

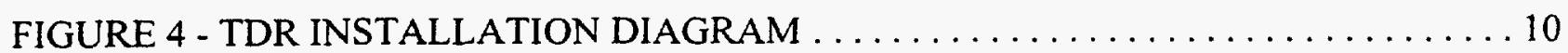

FIGURE 5 - CAU 110 CLOSURE FIELD SCHEDULE $\ldots \ldots \ldots \ldots \ldots \ldots \ldots \ldots \ldots$ 


\section{ACRONYMS AND ABBREVIATIONS}

ac

CAU

$\mathrm{cm}$

CP

CR

DCN

DOE

DOE/NV

DQO

EPA

FFACO

$\mathrm{ft}$

$\mathrm{ft}^{3}$

ha

in

$\mathrm{kg}$

$\mathrm{lb}$
Acre

Corrective Action Unit

centimeter

Closure Plan

Closure Report

Design Change Notice

U.S. Department of Energy

U.S. Department of Energy, Nevada Operations Office

Data Quality Objective

U. S. Environmental Protection Agency

Federal Facility Agreement and Consent Order

feet/foot

cubic feet

hectare

inch

Kilograms

Pound 
Date: August 6. 2001

\section{ACRONYMS AND ABBREVIATIONS (CONTINUED)}

\begin{tabular}{ll} 
m & meter \\
NAC & cubic meters \\
NDEP & Nevada Administrative Code \\
NTS & Nevada Division of Environmental Protection \\
PVC & Nevada Test Site \\
QAP & Polyvinyl Chloride \\
RCRA & Quality Assurance Plan \\
RWMS & Resource Conservation and Recovery Act \\
TDR & Radioactive Waste Management Site \\
yd & Time-Domain Reflectometry \\
yr & cubic yards \\
\hline
\end{tabular}


Closure Report - C.Al'110

Section: Exec. Summan

Revision: 1

Date August 6. 2001

\section{EXECUTIVE SUMMARY}

The Area 3 U-3ax/bl Disposal Unit, Corrective Action Unit (CAU) 110. which consists of one Corrective Action Site 03-23-04, was closed in accordance with the reissued (November 2000) Resource Conservation and Recovery Act (RCRA) Part B operational permit NEV HW009 (NDEP, 2000) and the Federal Facility Agreement and Consent Order (Nevada Division of Environmental Protection [NDEP] et al., 1996). The U-3ax/bl is a historic disposal unit within the Area 3 Radioactive Waste Management Site located on the Nevada Test Site (NTS). The unit, which was formed by excavating the area between two subsidence craters (U-3ax and U3bl), was operationally closed in 1987 . The U-3ax/bl disposal unit was closed under the RCRA, as a hazardous waste landfill.

Existing records indicate that, from July 1968 to December 1987, U-3ax/bl received $2.3 \times 10^{5}$ cubic meters $\left(8.12 \times 10^{6}\right.$ cubic feet) of waste. NTS nuclear device testing generated approxiriately 95 percent of the total waste volume disposed of in U-3ax/bl; 80 percent of the total volume was generated from the Waste Consolidation Project (Elletson and Johnejack, 1995).

Area 3 is located in Yucca Flat, within the northeast quadrant of the NTS. The Yucca Flat watershed is a structurally closed basin encompassing an area of approximately 780 square kilometers (300 square miles). The structural geomorphology of Yucca Flat is typical of the Basin and Range Physiographic Province. Yucca Flat lies in one of the most arid regions of the country. Water balance calculations for Area 3 indicate that it is continuously in a state of moisture deficit.

The U-3ax/bl Disposal Unit was closed in place by installing a RCRA equivalent cover. Following cover construction, a fence was installed around the cover to prevent accidental damage to the cover.

Closure of CAU 110 was completed using a NDEP approved Closure Plan, Revision 0, dated August 2000 (U.S. Department of Energy, Nevada Operations Office [DOE/NV], 2000). The closure plan was based on the recommendations presented in the characterization report (DOE/NV, 1999). The Area 3 U-3ax/bl Disposal Unit, CAU 110, was closed in the following manner:

- The Area 3 U-3ax/bl Waste Disposal Unit was closed in place by installing a monolayer vegetative cover. Following cover construction, a fence was constructed around the cover to prevent accidental damage to the cover. 
Closure Repor - CALI 110

Section: Evec Summan

Revision: 1

Date: August 6. 2001

Closure activities were certified by an independent registered professional engineer. Post-closure monitoring will consist of site inspections to determine the condition of the engineered cover and cover performance monitoring using Time-Domain Reflectometry arrays to monitor moisture migration in the cover. Any identified maintenance and repair requirements will be remedied within 60 working days of discovery and documented in writing at the time of repair. Results of all inspections/repairs for a given year will be addressed in a single report submitted annually to the NDEP. Soil moisture will be monitored within the cover for a period of at least two years prior to establishing performance criteria for NDEP regulatory purposes. 


\subsection{INTRODUCTION}

This Closure Report (CR) has been prepared for the Area 3 Radioactive Waste Management Site (RWMS) U-3ax/bl Disposal Unit Corrective Action Unit (CAU) 110 in accordance with the reissued (November 2000) Resource Conservation and Recovery Act (RCRA) Part B operational permit NEV HW009 (Nevada Division of Environmental Protection [NDEP], 2000) and the Federal Facility and Consent Order (FFACO) (NDEP et al., 1996). CAU 110 consists of one Corrective Action Site 03-23-04, described as the U-3ax/bl Subsidence Crater. Certifications of closure are located in Appendix A.

The U-3ax/bl is a historic disposal unit within the Area 3 RWMS located on the Nevada Test Site (NTS) (Figure 1). The unit, which was formed by excavating the area between two subsidence craters (U-3ax and U-3bl), was operationally closed in 1987 . The $U-3 a x / b l$ disposal unit was closed under the RCRA, as a hazardous waste landfill (Figure 2).

Existing records indicate that, from July 1968 to December 1987 , U-3ax/bl received $2.3 \times 10^{5}$ cubic meters $\left(\mathrm{m}^{3}\right)\left(8.12 \times 10^{6}\right.$ cubic feet [ $\left.\left.\mathrm{ft}^{3}\right]\right)$ of waste. NTS atmospheric nuclear device testing generated approximately 95 percent of the total waste volume disposed of in $\mathrm{U}-3 \mathrm{ax} / \mathrm{bl} ; 80$ percent of the total volume was generated from the Waste Consolidation Project (Elletson and Johnejack, 1995).

Area 3 is located in Yucca Flat, within the northeast quadrant of the NTS. The Yucca Flat watershed is a structurally closed basin encompassing an area of approximately 780 square kilometers (300 square miles). The structural geomorphology of Yucca Flat is typical of the Basin and Range Physiographic Province. Yucca Flat lies in one of the most arid regions of the country. Water balance calculations for Area 3 indicate that it is normally in a state of moisture deficit (U.S. Department of Energy, Nevada Operations Office [DOE/NV], 1999).

\subsection{PURPOSE}

The Area 3 RWMS U-3ax/bl Disposal Unit was identified as a historic RCRA site in the RCRA Part B Permit issued by NDEP Permit Number NEV HW009 (NDEP, 1995). This permit specifies that the unit be closed under Title 40 Code of Federal Regulations 265 (U. S. Environmental Protection Agency [EPA], 1996b) closure requirements for interim status facilities. Additionally, closure requirements, include U. S. Department of Energy (DOE) Order 5820.2A (DOE, 1988) and DOE Order 435.1. A Closure Plan (CP) (DOE/NV, 2000) was 


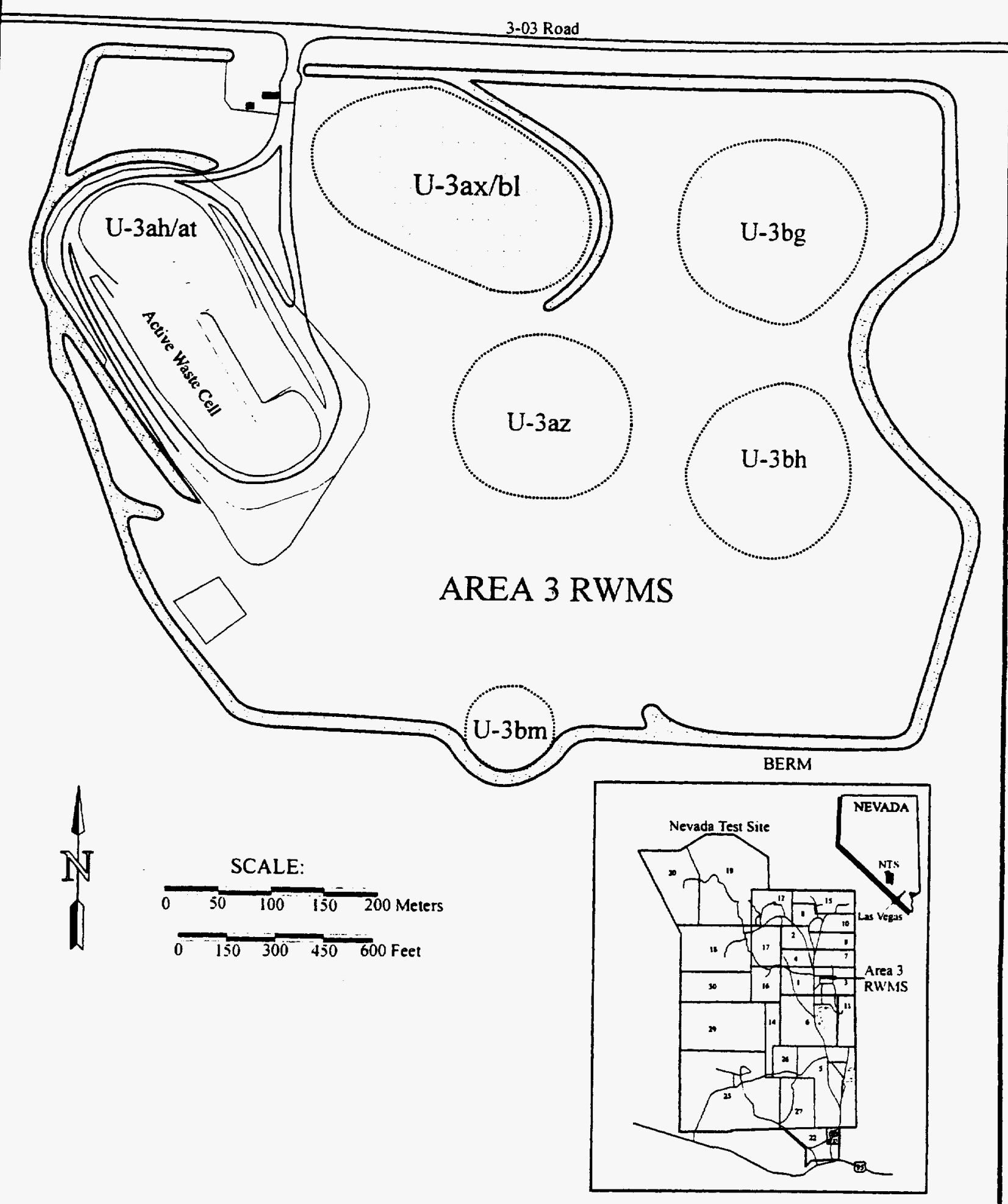

FIGURE 1

CAU 110 SITE LOCATION MAP 


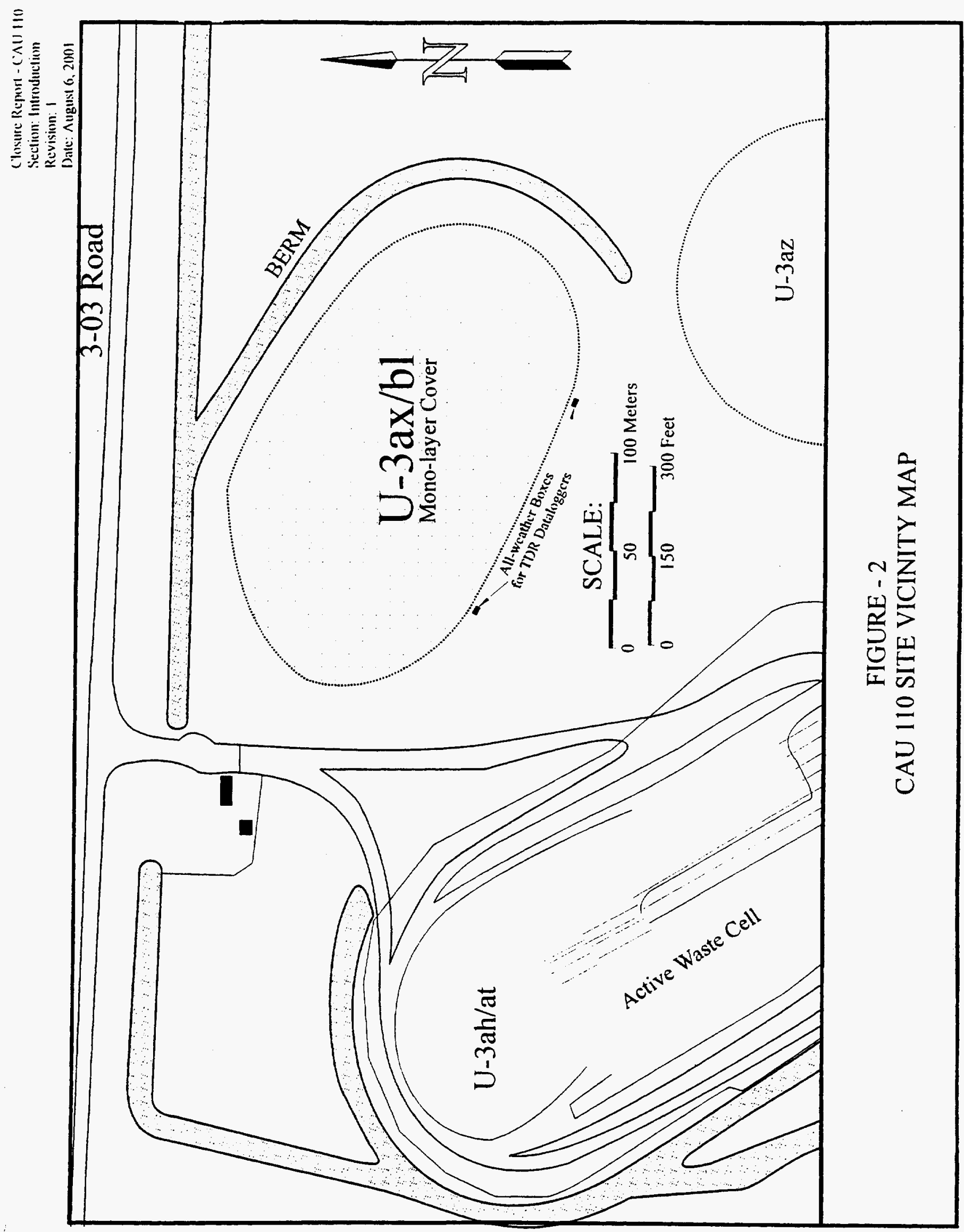


Closure Report - CAL' 110

Section: Introduction

Revision 1

Date: August 6.2001

developed for the U-3ax/bl Disposal Unit to address all of the above requirements. The purpose of this CR is to document that the closure of the Area 3 RWMS U-3ax/bl Disposal Unit complied with all of the CP closure requirements.

\subsection{SCOPE}

The recommended closure strategy for the Area 3 RWMS U-3ax/bl Disposal Unit was closure in place with a RCRA equivalent cover. The approved closure strategy consisted of the following activities:

- Preplanning and site preparation.

- Closure of 11 polyvinyl chloride (PVC) monitoring wells located around the perimeter of U3ax/bl. The CP identified only nine monitoring wells, two additional wells were located and closed during the closure field activities. Closure was accomplished by removing the PVC piping to a depth of 0.3 meters $(\mathrm{m})$ (1.0 foot [ft]) below existing grade. The remainder of the pipe was filled with grout, and a $0.3-\mathrm{m}(1-\mathrm{ft})$ concrete cap was installed over the monitoring well.

- Installation of four time-domain reflectometry (TDR) monitoring instrumentation nests in the cover to monitor cover performance.

- Construction of a monolayer cover by adding an additional $0.3 \mathrm{~m}$ (1 $\mathrm{ft}$ ) of fill on top of the operational cover.

- Seeding the monolayer cover with native shallow rooting vegetation.

- Installation of a irrigation system over the entire cover to augment natural rainfall and promote vegetation growth.

- Installation of a fence and signs around the cover to prevent animals from eating the native vegetation and keep unauthorized personnel from performing intrusive activities on the monolayer vegetative cover.

- Post-closure cover monitoring has been started. Cover performance monitoring will be performed for a two-year period prior to negotiating post-closure criteria with the NDEP. 
However, the Permit will be modified by NDEP to reflect post-closure inspections and subsidence survey requirements.

\subsection{CR CONTENTS}

This $\mathrm{CR}$ is divided into the following sections:

Section 1.0 - Introduction

Section 2.0 - Closure Activities

Section 3.0 - Waste Disposition

Section 4.0 - Closure Verification

Section 5.0 - Conclusions and Recommendations

Section 6.0 - References

The appendices of this document have been modified from the approved March 2001 FFACO outline. The following FFACO outline appendices have either not been included or revised as indicated below:

- Data Quality Objectives (DQOs) as developed in the Corrective Action Decision Document - DQOs were not developed for the closure of the Area 3 U-3ax/bl Disposal Unit. The monolayer cover was constructed to the criteria specified in the Construction Quality Assurance Plan.

- Confirmation Sampling Test Results - The U-3ax/bl Disposal Unit was closed by installation of a monolayer vegetative cover. Verification samples were not required.

- Waste Disposition Documentation - Hazardous or radiological waste was not generated during the closure activities. All waste was surveyed and disposed in the Area 3 Radiological Waste Management Area dumpster. The waste in the dumpster is disposed within the Area 23 landfill on a weekly basis.

- Modifications to the Post-Closure Plan - Modifications have not been proposed to the postclosure monitoring plan.

The following documents were used to develop this closure report:

- Characterization Report for Corrective Action Unit 110: Area 3 U-3ax/bl Disposal Unit. Nevada Test Site, Nevada. Rev. 0, DOE/NV-580; November 1999 (DOE/NV, 1999). 
- Closure Plan for Corrective Action Unit 110: Area 3 RWMS U-3ax/bl Disposal Unit. Nevada Test Site. Nevada; Rev. 0, DOE/NV-647, August 2000 (DOE/NV, 2000).

No DQOs were developed for the construction of the Area 3 U-3ax/bl Disposal Unit cover. The landfill cover construction activities were controlled by the construction drawings in the Construction Quality Assurance Plan located in Appendix A-1 of the CP (DOE/NV, 2000). 


\subsection{CLOSURE ACTIVITIES}

This section of the CR details the specific activities involved in the closure of CAU 110.

\subsection{DESCRIPTION OF CORRECTIVE ACTION ACTIVITIES}

Closure of CAU 110 was completed using the approved Closure Plan for Corrective Action Unit 110: Area 3 RWMS U-3ax/bl Disposal Unit. Nevada Test Site. Nevada, Revision 0, dated August 2000 (DOE/NV, 2000). The CP was based on the recommendations in the Characterization Report for Corrective Action Unit 110: U-3ax/bl Disposal Unit. Nevada Test Site, Nevada (DOE/NV, 1999). The characterization report was developed from a number of characterization studies performed for the DOE/NV Waste Management Division. Before the closure activities began, the following prefield activities were completed:

- Preparation of National Environmental Policy Act documentation.

- Preparation of the Site-Specific Health and Safety Plan.

- Preparation of the Field Management Plan.

The following is the scope of the closure actions implemented for CAU 110. Hold and check points identified in the Closure Plan Construction Quality Assurance Plan (DOE/NV, 2000) were approved in the field and a copy of the completed form is provided in Appendix B.

\subsubsection{Installation of Time-Domain Reflectometry Instrumentation Nests}

The following activities were required to install the post-closure monitoring cover performance instrumentation. TDR instruments are used to calculate the moisture content of the soil at a specific location. By installing TDR probes at a number of depths, a moisture profile can be developed. This vertical moisture profile can be used to verify that cover design is effectively removing moisture from the vegetative cover. The TDR installation field activities were conducted between October 29, 2000 through November 7, 2000:

- Based on the operational cover geotechnical analysis (DOE/NV, 2000), a backfill compaction standard of 80 percent was established. The compaction standard was developed for a number of different compaction techniques (Appendix $\mathrm{C}$ ). A test pit located 
just outside of the cover was used to determine the number of passes, using different equipment, required to achieve the required 80 percent compaction. Performance standards were established for the following compaction techniques: foot tamping, backhoe wheel rolling, and mechanical thumping.

- Four 0.6-m (2-ft) deep trenches were excavated across the cover (Figure 3 ) to bury the TDR cables. The trenches were angled so that two sets of " $V$ " trenches were formed. The center of the "V" was located just outside of the monolayer cover. The cabling from the two TDR nests were wired into a data logger located on a instrument panel found at the point of each "V". To protect the cabling from moisture, the cabling was run through a sealed 7.62 centimeter $(\mathrm{cm})(3$ inch [in]) diameter flexible PVC conduit.

- The four trenches were backfilled and wheel-rolled according to the performance standard developed to achieve the specified 80 percent compaction.

- Four TDR nests were excavated (Figure 3). Each nest was excavated to a depth of $1.8-\mathrm{m}$ (6-ft) below ground surface. The excavation followed the benching requirements specified in the Design Change Notice (DCN) number: DCN 01/10-449. A total of eight TDR instruments was installed in each nest. Each TDR instrument was staggered within the excavation to prevent any preferential pathways for moisture to enter the monitoring system. The bottom TDR instrument was installed by hand excavating $0.3-\mathrm{m}(1-\mathrm{ft})$ into the operational cover. The soil on top of all TDR instruments was compacted by using the foottamping performance standard. Areas of the excavation not directly over a TDR instrument were compacted using the mechanical thumper compaction standard. The top TDR instrument was placed on the ground surface. An additional $0.3-\mathrm{m}(1-\mathrm{ft})$ of soil was placed on top of the TDR instrument and compacted to 80 percent using the foot-tamping performance standard. A diagram of a TDR monitoring nest is provided as Figure 4.

- The two data loggers are connected to a wireless signaling system which connect to a land based telephone line located in the Area 3 RWMS office building. This system allow offsite downloading of TDR data, which reduces monitoring costs.

- TDR soil moisture calibration curves (Appendix I) were developed for the U-3ax/bl by using cover soil compacted to 80 percent. The soil surrounding the TDR probe is moistened to a known moisture content. The reading is recorded and the experiment is repeated using different soil moisture percentages until a calibration curve is developed. Direct TDR 


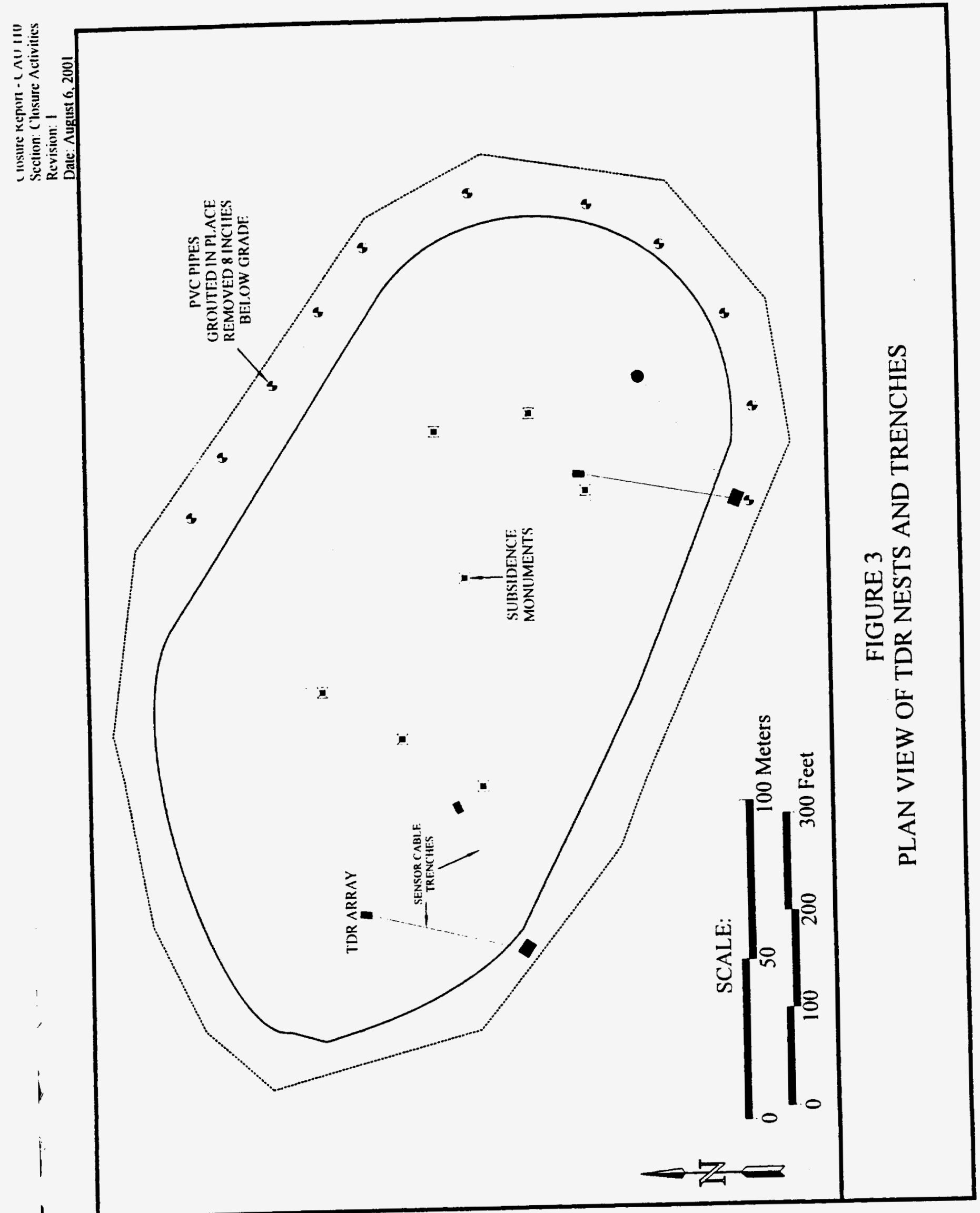



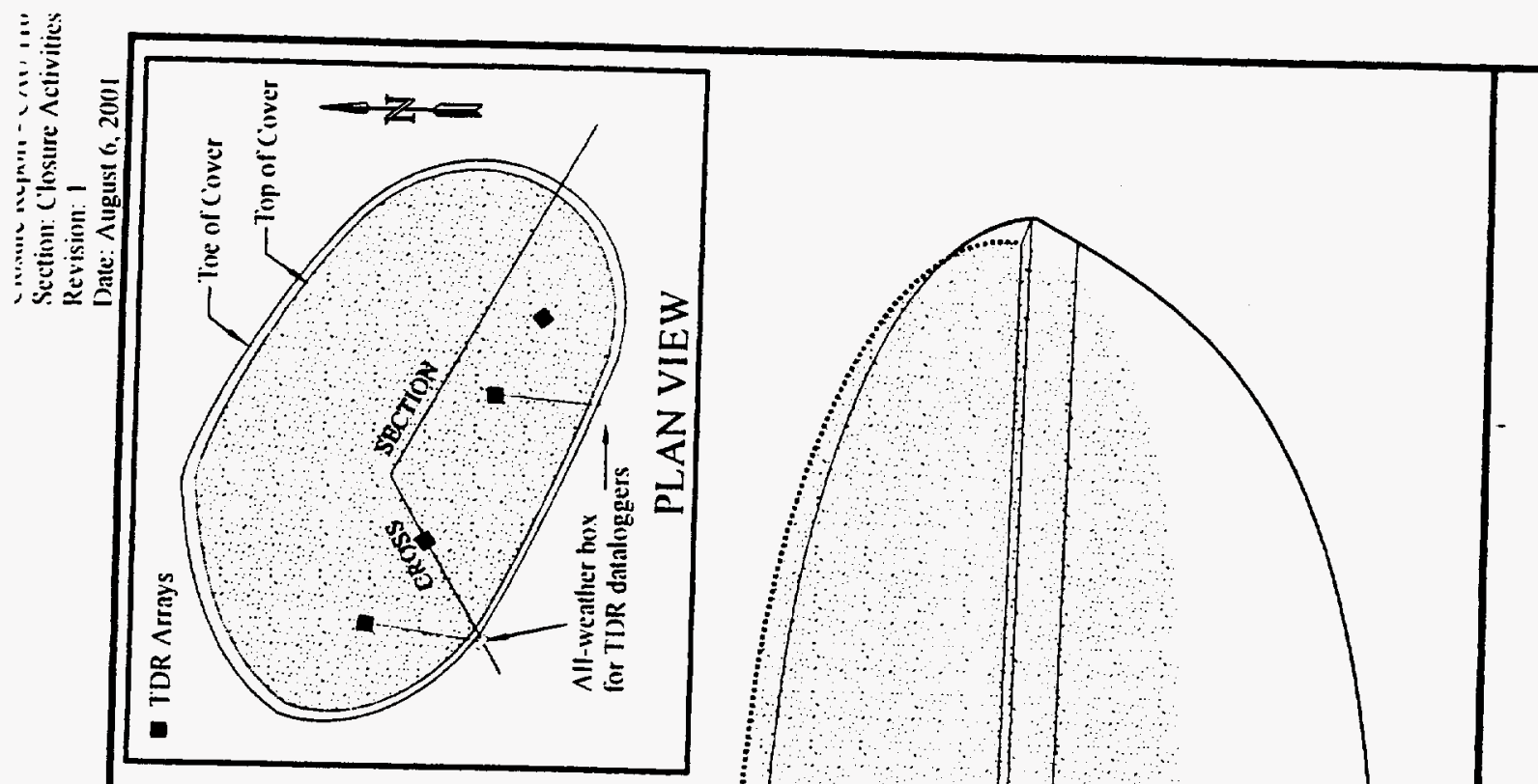
measurements from the TDR nests are then compared to the calibration curve and a soil moisture percentage is estimated. Additional information on the post-closure monitoring program is provided in Section 5.1 of this CR.

\subsubsection{Installation of Monolayer Cover}

This section outlines the activities required to construct the monolayer cover. An $2.5-\mathrm{m}$ to $3-\mathrm{m}$ ( 8-ft to 10-ft) operational cover was constructed over the U-3ax/bl waste unit in 1987. Subsidence and hydrologic modeling (DOE/NV, 2000) determined that only an additional $0.3 \mathrm{~m}$ ( $1 \mathrm{ft}$ ) of soil was required to meet the monolayer cover performance criteria. The monolayer cover installation field activities were conducted between October 30, 2000 through December 7, 2000. Specific construction details are provided below.

- Native soil was obtained from the Area 3 borrow pit located approximately 5 kilometers ( 3 miles) southwest of the Area 3 RWMS. Geotechnical tests of the borrow pit soil confirmed that it was similar to the material used in constructing the operational cover in 1987.

- Bull dozers and front-end loaders were used to stockpile borrow material. On average four belly dump trucks were used to transport the borrow material to the U-3ax/bl cover. Each belly dump truck transported approximately $14.2 \mathrm{~m}^{3}$ (18 cubic yards [yd $\mathrm{yd}^{3}$ ) of borrow material.

- Due to surface contamination radiological posting requirements and to minimize/eliminate the requirement to decontaminate equipment, belly dump trucks were restricted to areas of the cover that had imported borrow material spread on the surface. A front-end loader, dozer, and grader were used to push the borrow material onto the U-3ax/bl cover. This operation was conducted in a manner that prevented any equipment coming in contact with the original operational cover surface. Approximately $11,571 \mathrm{~m}^{3}\left(15,125 \mathrm{yd}^{3}\right)$ of borrow material was transported to and placed on to the operational cover.

- Survey grade stakes were installed to direct cover grading operations across the 3 hectares (ha) ( 7.5 acre [ac]) monolayer cover. After the final grade was established across the monolayer cover, a final elevation survey was conducted to "as-built" the monolayer cover. 
- Seven subsidence monuments were installed across the monolayer cover. The locations of the subsidence monuments are provided in Figure 3. Each monument was surveved and location and elevation information engraved on a brass plate attached to the center of each monument.

\subsubsection{Planting Native Vegetation}

To enhance the moisture removal capabilities of the monolayer cover, a mixture of shallow rooting native plants were identified for the $U-3 a x / b l$ monolayer cover. The native plants will intercept committed precipitation before it can reach the waste unit. The planting field activities were conducted between November 28, 2000 through December 6, 2000. Specific construction details are provided below.

- The monolayer cover surface was disked to a depth of $0.3 \mathrm{~m}(1 \mathrm{ft})$ to provide an ideal soil condition for the establishment of the selected native species seeds.

- Seeding was accomplished at a broadcast-seeding rate of 22.79 kilograms $(\mathrm{kg})$ per ha $(20.33$ pounds [lb] per ac) of pure live seed. Seeds were planted using a tractor-drawn seed drill. A drag chain was used to cover the planted seeds. A list of the species and relative abundance is provided in Appendix D.

- Straw mulch was applied over the seeded cover to protect the seeds from erosion and to increase soil moisture content in the upper $15-\mathrm{cm}(6-\mathrm{in})$ of the cover. The straw was applied at a rate of $4,484 \mathrm{~kg} / \mathrm{ha}(4,000 \mathrm{lb} / \mathrm{ac})$ using a straw blower. The mulch is held in place by crimping the ends of the straw into the cover using a tractor-drawn disk crimper.

- In order to establish the seeds that were installed in the monolayer cover, the natural precipitation required augmentation. The Area $3 \mathrm{RWMS}$ receives on average $17 \mathrm{~cm}$ per year (yr) (6.69 in/yr); optimal revegetation requires $25 \mathrm{~cm} / \mathrm{yr}$ ( $9.84 \mathrm{in} / \mathrm{yr})$ of rainfall. A sprinkling irrigation system was installed across the monolayer cover. The irrigation system is fed from a Baker tank that is filled by water trucks on an "as needed" basis. The goal of the irrigation program is to augment natural precipitation and keep the upper $15 \mathrm{~cm}(6 \mathrm{in})$ of the monolayer cover moist. Irrigation activities are scheduled on an "as needed" basis from January 2001 through June 2001.

- After the vegetation has become established, the irrigation system will be removed from the site. Irrigation activities are scheduled to be completed by June 30, 2001. 


\subsubsection{Closure of PVC Monitoring Wells}

Nine PVC monitoring wells were identified in the CP, however eleven PVC monitoring wells were installed along the slope of the U-3bl portion of the U-3ax/bl waste disposal unit. It is thought that these PVC monitoring wells were installed to provide waste cell water content information through neutron logging. During the U-3ax/bl landfill operations and installation of the operational cover, the majority of these PVC wells were crushed within $6 \mathrm{~m}(20 \mathrm{ft})$ of the ground surface. Since these PVC monitoring wells could not be used for any post-closure monitoring purposes, they were closed following Nevada Administrative Code (NAC) 534.421, Plugging: Wells for Purposes Other Than Water Wells. The well closure activities were conducted between November 28, 2000 through December 6.2000. Closure activities consisted of the following:

- A $0.3-\mathrm{m}(1-\mathrm{ft})$ long by $0.3-\mathrm{m}(1-\mathrm{ft})$ wide by $20-\mathrm{cm}(8-\mathrm{in})$ deep hole was hand dug around each PVC monitoring well.

- A hand saw was used to cut the exposed PVC piping flush with the bottom of the excavated surface.

- A neat cement grout was used to fill the PVC monitoring well from the base or crushed end to the ground surface. The neat cement grout was allowed to set and additional material was placed into the monitoring well if any settling occurred.

- A $0.3-\mathrm{m}(1-\mathrm{ft})$ long by $0.3-\mathrm{m}(1-\mathrm{ft})$ wide by $20-\mathrm{cm}(8-\mathrm{in})$ high cement grout plug was poured to cover the top of the closed monitoring well. This plug blocks any potential preferential pathway for runoff to migrate into the U-3ax/bl waste unit.

\subsubsection{Installation of Monolayer Cover Fence}

To prevent indiscriminate access of personnel or animals to the monolayer vegetative cover, a fence was installed around the cover. A single entry gate was installed near the northwest corner of the cover (Figure 3). Site access information and identification signs are installed on the fencing to meet hazard notification requirements. The fence construction activities were conducted between December 7, 2000 through January 25, 2001. Detailed fencing construction details are provided below. 
- Fence posts were driven into the ground in $1.5-\mathrm{m}(5-\mathrm{ft})$ intervals around the cover. Each fence post was driven approximately $0.56-\mathrm{m}(22-\mathrm{in})$ into the ground with approximately 1.2$\mathrm{m}(4-\mathrm{ft})$ of fence post exposed.

- Four smooth strand wire lengths were attached between the fence posts around the monolayer vegetative cover. The lengths of smooth wire were installed as close to equal distant apart as possible.

- A grader was used to excavate an approximately $0.3-\mathrm{m}(1-\mathrm{ft}) \mathrm{v}$-shaped trench of soil from the base of the fence. This excavation was required for the installation of chicken wire mesh around the exterior of the monolayer vegetative cover. The chicken wire mesh is required to keep animals from borrowing under the fence and destroying the vegetation.

- After the chicken wire mesh has been installed, the grader was used to replace the $0.3-\mathrm{m}$ (1-ft) of soil that was removed.

- Warning signs were installed on the fence every $61-\mathrm{m}(200-\mathrm{ft})$ along the exterior of the $\mathrm{U}-3 \mathrm{ax} / \mathrm{bl}$ monolayer vegetative cover.

\subsection{DEVIATIONS FROM CP AS APPROVED}

Two DCNs and an E-mail were requested and approved during construction of the monolayer vegetative cover. Each change was associated with the Construction Quality Assurance Plan (QAP) located in Appendix A-1 of the Closure Plan (DOE/NV, 2000). Each change is discussed separately below and are found in Appendix E. In addition to the engineering DCNs and e-mail, two additional PVC monitoring wells were discovered and closed per Section 2.1.4.

\subsubsection{DCN No. 01/10-448}

This DCN was required to support the excavation of the TDR installation nests. The Construction QAP drawing JS-003-00004-C3 required that the construction crew use portable shoring to support the side walls of the excavation. The drawings did not allow the use of benching techniques to stabilize the sides of the excavation. No shoring was available so the Construction QAP drawing was modified to allow for benching on both sides of the excavation. 
Closure Report - CAU 110

Section: Closure Activities

Revision: ]

Date: August 6. 2001

\subsubsection{DCN No. 01/10-449}

This DCN clarified how the compaction performance standard would be established. The size of the test pit was reduced from $1-\mathrm{m}(3-\mathrm{ft})$ by $4.9-\mathrm{m}(16-\mathrm{ft})$ to $1-\mathrm{m}(3-\mathrm{ft})$ by $1.8-\mathrm{m}(6-\mathrm{ft})$. Reducing the size of the test pit did not affect the compaction performance standard accuracy or methodology. Reducing the size of the test pit provided the same results while reducing the time and resources required to obtain the compaction performance standard data.

\subsubsection{November 11, 2000 E-mail}

The Bechtel Nevada design engineer assigned to the U-3ax/bl Disposal Unit closure project, authorized a deviation from the Construction QAP in an November 11, $2000 \mathrm{E}$-mail. The E-mail was to be followed with a DCN formalizing this change. This DCN was not issued during the construction phase of the project. In lieu of a DCN, the "as constructed" survey data were evaluated against the authorization requirements of the E-mail and these changes were incorporated into the final "as built" engineering drawings. The e-mail authorized reducing the size of the final fence perimeter. The final fence location was reduced to the perimeter of the old radiological delineation fence line. The Construction QAP drawing JS-003-00004-C2 fence perimeter was larger than is required to address radiological or safety concerns. By reducing the perimeter of the fence line to the original radiological control perimeter, the amount of acreage requiring post-closure inspection/maintenance was significantly reduced.

In addition to reducing the fence perimeter, the location of the access gate was relocated from the south side of the cover to the west side. The gate location was moved to provide easier access into the U-3ax/bl monolayer vegetative cover from the Area 3 RWMS office area.

\subsubsection{PVC Monitoring Well Closure}

Two additional PVC monitoring wells were discovered hidden in low areas filled with tumble weeds. These monitoring wells were similar in construction to the nine previously identified PVC monitoring wells. These newly identified wells were closed in the same manner and time frame as the nine PVC monitoring wells identified in the CP.

\subsection{CAU 110 CLOSURE ACTIVITIES SCHEDULE}

The completed closure field activities schedule can be found in Figure 5. Activities such as post- 
closure monitoring and irrigation of the vegetative cover are ongoing and are not included in the schedule.

\subsection{CAU 110 FINAL SURVEY “AS BUILT” DIAGRAMS}

The final engineering "as built" drawings for the CAU 110 Area 3 U-3ax/bl Disposal Unit are provided in Appendix $\mathrm{F}$ of this report. The information included in Appendix $\mathrm{C}$ (compaction performance standard geotechnical data) and Appendix E (engineering DCNs) along with final survey data were used to complete the final engineering "as built" drawings provided in Appendix F. 


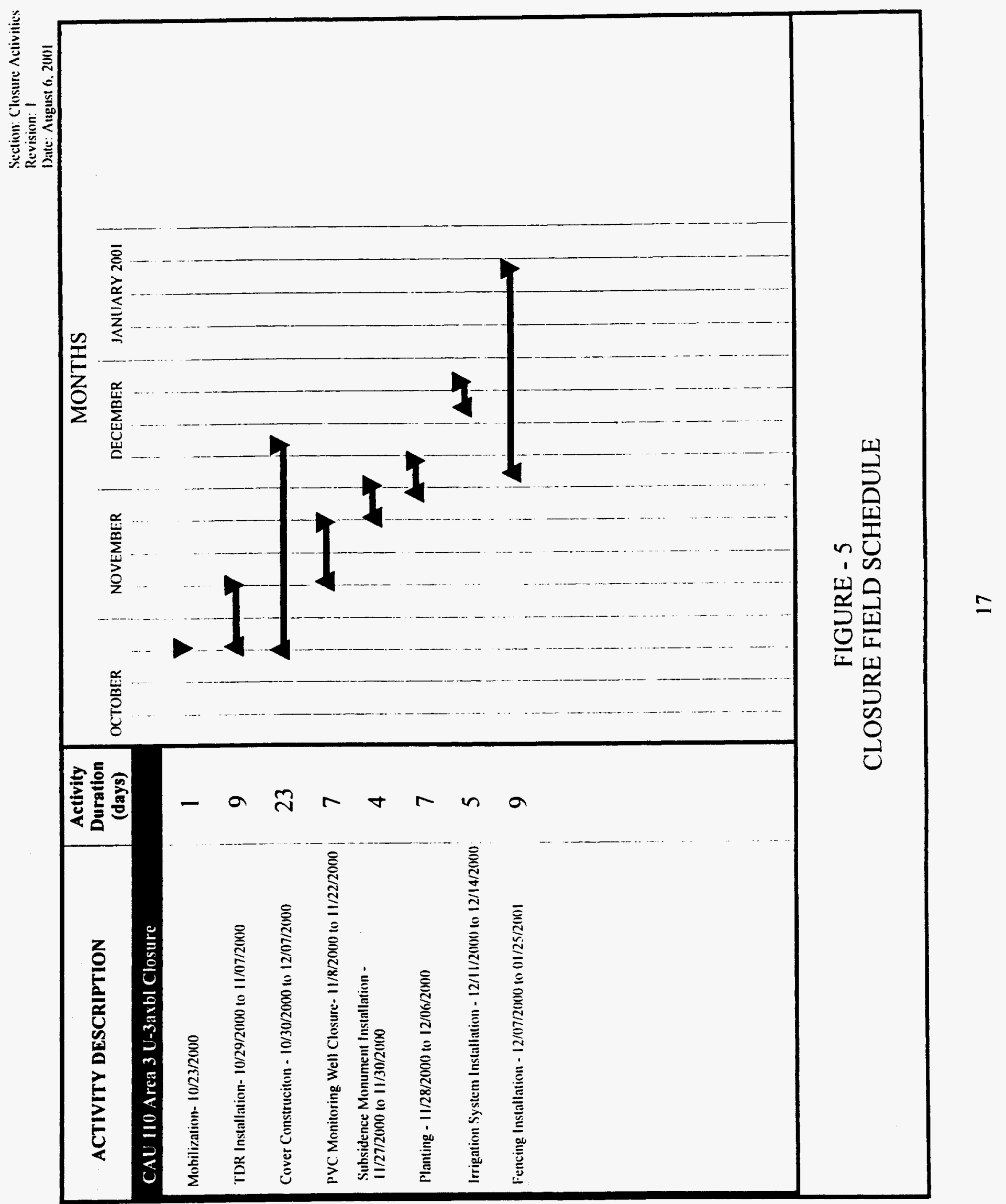


Closure Repon - CAl' II0 Section. Closure Activilies Revision 1

Date: August 6.2001

\section{THIS PAGE INTENTIONALLY LEFT BLANK}




\subsection{WASTE DISPOSITION}

Waste generated from CAU 110 closure activities consisted of non-radiologically impacted personal protective equipment and sanitary trash. All waste was surveyed to verify that it met release criteria. Once verified, the waste was bagged and disposed of in the Area 3 RWMS dumpster. The waste in the dumpster is disposed within the Area 23 landfill on a weekly basis. 
Closure Repon - CALI 110 Section: Waste Disposition Revision: 1

Date: August 6.2001

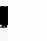

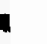

THIS PAGE INTENTIONALLY LEFT BLANK 


\subsection{CLOSURE VERIFICATION}

The U-3ax/bl Disposal Unit was closed by constructing an engineered cover. Closure verification consisted of the completion of the CAU 110 Remediation, U-3ax/bl Disposal Unit Closure Approval Matrix and Checklist located in Appendix B. Guidance for the cover construction and verification was provided in the approved Construction QAP (Appendices A-1, DOE/NV, 2000).

\subsection{DATA QUALITY ASSESSMENT}

The closure of the Area 3 U-3ax/bl Disposal Unit did not require the development of DQOs. Following EPA guidance for landfill closures, a Construction QAP was developed (EPA. 1991). The Construction QAP included a CAU 110 U-3ax/bl Disposal Unit Closure Approval Matrix and Checklist (Appendix B) which verified that all of the quality assurance check and hold points were verified in the field prior to progressing to the next closure task.

\subsection{LAND-USE RESTRICTIONS}

The Area $3 \mathrm{U}-3 \mathrm{ax} / \mathrm{bl}$ Disposal Unit has been closed in accordance with the approved closure plan (DOE/NV, 2000). This landfill has been fenced and posted with signs reading "Subsurface Radiologic Contamination". The future use of any land related to the U-3ax/bl Disposal Unit is restricted from any activity that may alter or modify the containment control as approved by the state of Nevada and identified in this document or any other CAU 110 documentation unless appropriate concurrence from the NDEP is obtained in advance.

The specific location and monitoring requirements for the Area $3 \mathrm{U}-3 \mathrm{ax} / \mathrm{bl}$ site was recorded on the CAU Use Restriction Information Form. The information on the completed form is added into the DOE/NV Facility Information Management System and the Central Data Repository. The original CAU Land Use Restriction Form was filed within the U-3ax/bl Disposal Unit project file. A copy of the CAU Use Restriction Information is included in Appendix G of this report. The post-closure monitoring requirements for CAU 110 are outlined in Section 5.1. 
Closure Repon - CAL 110

Section: Closure Verification

Revision: 1

Date: August 6. 2001

THIS PAGE INTENTIONALLY LEFT BLANK

m 


\subsection{CONCLUSIONS AND RECOMMENDATIONS}

Closure of the Area 3 U-3ax/bl Disposal Unit was accomplished by completing the following tasks:

- Closure of eleven PVC monitoring wells located around the perimeter of U-3ax/bl. The CP identified only nine monitoring wells, two additional wells were located and closed during the closure field activities. Closure was accomplished by removing the PVC piping to a depth of $0.3-\mathrm{m}(1-\mathrm{ft})$ below existing grade. The remainder of the pipe was filled with grout and a $0.3-\mathrm{m}(1-\mathrm{ft})$ concrete cap installed over the monitoring well.

- Installation of four TDR cover monitoring instrumentation nests to monitor cover performance.

- Construction of a monolayer cover by adding an additional $0.3-\mathrm{m}(1-\mathrm{ft})$ of fill on top of the operational cover.

- Seeding the monolayer cover with native shallow rooting vegetation.

- Installation of a irrigation system over the entire cover to augment natural rainfall and promote vegetation growth.

- Installation of a fence and signs around the cover to prevent animals from eating the native vegetation and keep unauthorized personnel from performing intrusive activities on the monolayer vegetative cover.

\subsection{POST-CLOSURE MONITORING REQUIREMENTS}

The components of the Area 3 U-3ax/bl Disposal Unit post-closure monitoring plan are provided below.

\subsubsection{Inspections}

Inspections will be done on a quarterly basis. Inspections will consist of visual observations to check that the cover is intact. Each site inspection will be documented on a site inspection form. 
Closure Report - CAU 110

Section: Conclusions

Revision: 1

Date: August 6, 2001

The post-closure inspection will consist of the following elements:

- A detailed inspection of the cover fencing. The perimeter of the fencing will be walked by the inspector and the condition of the fencing and chicken wire, warning signs, and entrance gate and lock will be documented every six months.

- The condition of the seven survey subsidence markers will be inspected every six months. In addition, on an biannual basis, all seven survey markers will be resurveyed to determine if the cover has subsided.

- During each inspection, any changes in the condition of the cover or fenced area will be documented. Specific changes noted on the current condition of the cover include, but are not limited to, trash/debris within the fenced compound, animal burrows/nesting activity, or erosion of the cover.

- Cracks or settling imperfections ( $<15 \mathrm{~cm}$ [6 in] deep) on the cover will be documented and will be scheduled for repair on an annual basis. Larger disruptions of the cover (animal burrows or erosion) will be immediately evaluated and repaired within 90 days.

- All repair work should preserve the original cover "as built" design. If the cover repair requires modification of the cover design, $\mathrm{DOE} / \mathrm{NV}$ will present a formal design modification request to the NDEP prior to making the design modification.

\subsubsection{Cover Monitoring}

The U-3ax/bl Disposal Unit cover is designed to limit infiltration into the disposal unit. Waste cover performance will be monitored using TDR soil water content sensors buried at various depths within the waste cover to provide water content profile data. Soil water content profile data will demonstrate whether the cover is performing as expected.

TDR probes have been buried in the cover at depths of 0.3 to $2.4 \mathrm{~m}$ ( 1 to $8 \mathrm{ft}$ ), one probe every $0.3 \mathrm{~m}(1 \mathrm{ft})$. TDR probes are installed at a distance of $36.5 \mathrm{~m}(120 \mathrm{ft})$ from the edge of the cover. A profile of eight probes (a stack) was repeated at four locations across the cover (Figure 4). Moisture content data from the TDR moisture probes will be stored on a datalogger. The datalogger can be programmed to collect data at any frequency of interest; however, the recommended data collection frequency is once per day. The recommended frequency of remote data download and data analysis is once per week. 


\subsubsection{Compliance Criteria}

The U-3ax/bl Disposal Unit cover boundary is defined by the fence installed around the cover. The fence encloses the approximately 3 -ha $(7.5-\mathrm{ac})$ site. The point of compliance is the depth of the deepest TDR soil moisture probe. Compliance will be set based on soil moisture content; however, the specific criteria will not be established until the cover has had sufficient time to reach equilibrium. The cover will be irrigated, as needed, to supplement rainfall for the first year in order to aid in establishing vegetation. Once the moisture content within the cover reaches equilibrium, soil moisture trigger values will be agreed upon with the NDEP.

The following have been established for the post-closure monitoring program:

1) Notify the NDEP of noncompliance within 14 days of determining that the cover is not operating according to the established compliance criteria.

2) iron-critical (cracks or settling imperfections equal to or less than $15 \mathrm{~cm}$ [6 inj deep on the cover) maintenance activities will be compiled during the fiscal year and addressed in the following fiscal year. The NDEP will be provided with the list of non-critical cover maintenance requirements each August.

3) Cracks or settling imperfections greater than $15 \mathrm{~cm}(6 \mathrm{in})$ deep which extend $1.0 \mathrm{~m}(3 \mathrm{ft})$ or more on the cover (through animal burrows, erosion, or subsidence) will be evaluated and repaired within 60 days of detection.

4) On an twice a year basis, all seven survey markers located on the cover will be resurveyed to determine if the cover has subsided.

After NDEP notification of noncompliance, a work plan will be submitted to the NDEP within 90 days outlining the proposed remediation/investigation plan. All corrective actions will be documented in an annual post-closure monitoring report and a copy submitted to the NDEP.

\subsubsection{Maintenance and Repair}

The post-closure inspection will be done, at a minimum, once every three months. All inspection and maintenance activities conducted during the year will be documented and submitted to the NDEP. The annual letter report will be provided on or before August 31 th of each year of the post- closure inspection period. The post-closure inspection period duration is proposed to be 
five years. After five years of post-closure monitoring, the permittee may submit a request to NDEP to reevaluate the monitoring program and/or schedule. The annual letter report will include the following information:

- Brief narrative and pictures from post-closure inspection activities.

- U-3ax/bl Disposal Unit cover inspection logs.

- Moisture content profiles through the previous year.

- Maintenance and repair documentation (if any).

- Specific recommendations for non-standard maintenance or changes in post-closure monitoring.

All closure and post-closure monitoring documentation will be retained in project files and is available upon request.

\subsection{RECOMMENDATIONS}

Based upon the completion of site activities, it is requested that a notice of completion be provided by the NDEP for CAU 110. Upon closure approval, CAU 110 will be promoted from Appendix III to Appendix IV of the FFACO, "Closed Corrective Action Units." 


\subsection{REFERENCES}

Bechtel Nevada, 2000. Site Specific Health and Safetv Plan for Closure Activities at Corrective Action Unit 110: Area 3 RWMS U-3ax/bl Disposal Unit, October 2000. Las Vegas, NV.

DOE, see U.S. Department of Energy.

DOE/NV, see U.S. Department of Energy, Nevada Operations Office.

Elletson, L. W., and K. R. Johnejack, 1995. Waste Inventory Report for the U-3ax/bl Disposal Unit at the Nevada Test Site. Reynolds Electrical \& Engineering Co., Inc. DOE/NV/11432-193.

EPA, see U.S. Environmental Protection Agency.

NAC, see Nevada Administrative Code.

NDEP, see Nevada Division of Environmental Protection.

Nevada Administrative Code, 534.421, Plugging: Wells for Purposes Other Than Water Wells.

Nevada Division of Environmental Protection, November 2000. Permit For a Hazardous Waste Facility, Permit Number NEV HW009; Section VIl.B.7.

Nevada Division of Environmental Protection, U.S. Department of Energy, and U.S. Department of Defense, April 1996. Federal Facilities Agreement and Consent Order (FFACO) of 1996.

U.S. Department of Energy, 1988. "Radioactive Waste Management," DOE Order 5820.2A, U.S. Department of Energy, Washington. D.C.

U.S. Department of Energy, Nevada Operations Office, 1999. Characterization Report for Corrective Action Unit 110: Area 3 U-3ax/bl Disposal Unit. Nevada Test Site. Nevada, DOE/NV--580, November 1999, Las Vegas, NV. 


\subsection{REFERENCES (Continued)}

U.S. Department of Energy, Nevada Operations Office, 2000. Closure Plan for Corrective Action Unit 110: Area 3 RWMS U-3ax/bl Disposal Unit. Nevada Test Site, Nevada, DOE/NV-647, August 2000, Las Vegas, NV.

U.S. Department of Energy, Nevada Operations Office, 2000. Field Management Plan for Corrective Action Unit 110: Area 3 U-3ax/bl Disposal Unit. Nevada Test Site, Nevada, October 2000, Las Vegas, NV.

U.S. Environmental Protection Agency, 1991. Design and Construction of RCRA/CERCLA Final Covers, EPA/625/4-91/025, Washington, D.C.

U.S. Environmental Protection Agency, 1996a. 40 Code of Federal Regulations 265.310, Interim Status Standards for Owners and Operators of Hazardous Waste Treatment. Storage and Disposal Facilities Closure and Post Closure Care, Washington, D.C.

U.S. Environmental Protection Agency, 1996b. 40 Code of Federal Regulations 265.90, Interim Status Standards for Owners and Operators of Hazardous Waste Treatment, Storage and Disposal Facilities Ground Water Monitoring, Washington, D.C. 
Closure Report - CALI 110

Section: Appendix A

Revision: 1

Date: August 6.2001 
Closure Repon - CALI 110

Section: Appendiv A

Revision: I

Dale: August 6. 2001

\section{THIS PAGE INTENTIONALLY LEFT BLANK}




\section{CERTIFICATION OF CLOSURE BY THE \\ NATIONAL NUCLEAR SECURITY ADMINISTRATION \\ NEVADA OPERATIONS OFFICE}

I certify under penalty of law that the Area 3 U-3ax/bl Disposal Unit, Corrective Action Unit 110, located in Area 3 at the Nevada Test Site has been closed in accordance with the approved Closure Plan for CAU No. 110: Area 3 RWMS U-3ax/bl Disposal Unit. Nevada Test Site dated August 2000 and the Permit for a Hazardous Waste Management Facility Number NEV HW009. United States Department of Energy. Nevada Operations Office, Nevada Test Site, dated November 2000. All measures required in the Closure Plan and applicable Resource Conservation and Recover Act 42 U.S.C. 6901-6991i and Title 40 CFR 260-268 have been fully implemented and that, to the best of my knowledge, no violations exist.

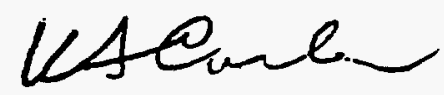

Kathleen A. Carlson, Manager

NNSA Nevada Operations Office

$6 / 7 / 0)$

Date

National Nuclear Security Administration

Nevada Operations Office

P.O. Box 98518

Las Vegas, NV 89193-8518 


\section{CERTIFICATION OF CLOSURE BY THE INDEPENDENT PROFESSIONAL ENGINEER}

I, Dean D. Nelson, a registered Professional Engineer, hearby state that I have reviewed the Closure Plan for the Closure of the Area 3 U-3ax/bl Disposal Unit, Corrective Action Unit 110, located in Area 3 at the Nevada Test site and am familiar with the rules and regulations of Title 40 §CFR 265.90 and $\$ 265.310$ pertaining to the closure of this Corrective Action Unit has been performed with the exception of that stated in Section 2.2, in accordance with the approved Closure Plan for CAU No. 110 Area 3 U-3ax/bl Disposal Unit. Nevada Test Site dated August 2000 and the Permit for a Hazardous Waste Management Facility Number NEV HW009. United States Deparment of Energy, Nevada Operations Office. Nevada Test Site, dated November 2000.

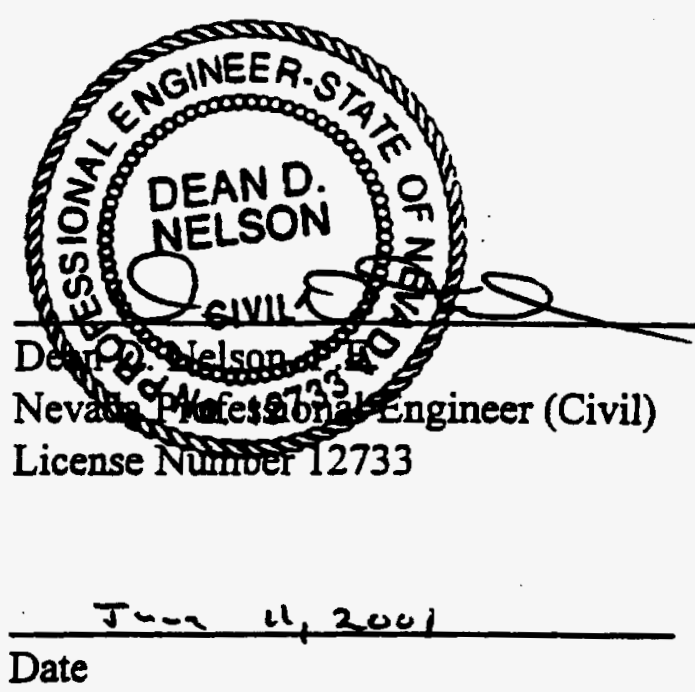

PEER Consultants, P.C.

2439 Losee Road, Suite 1C

North Las Vegas, Nevada 89109 
Closure Report - CAL' 110

Section: Appendix B

Revision. 1

Date: August 6. 2001

\section{APPENDIX B}

\section{APPROVAL MATRIX AND CHECKLIST}


Closure Repon - CALI 110 Section: Appendix B

Revision: I

Date. August 6. 2001

\section{THIS PAGE INTENTIONALLY LEFT BLANK}

w 


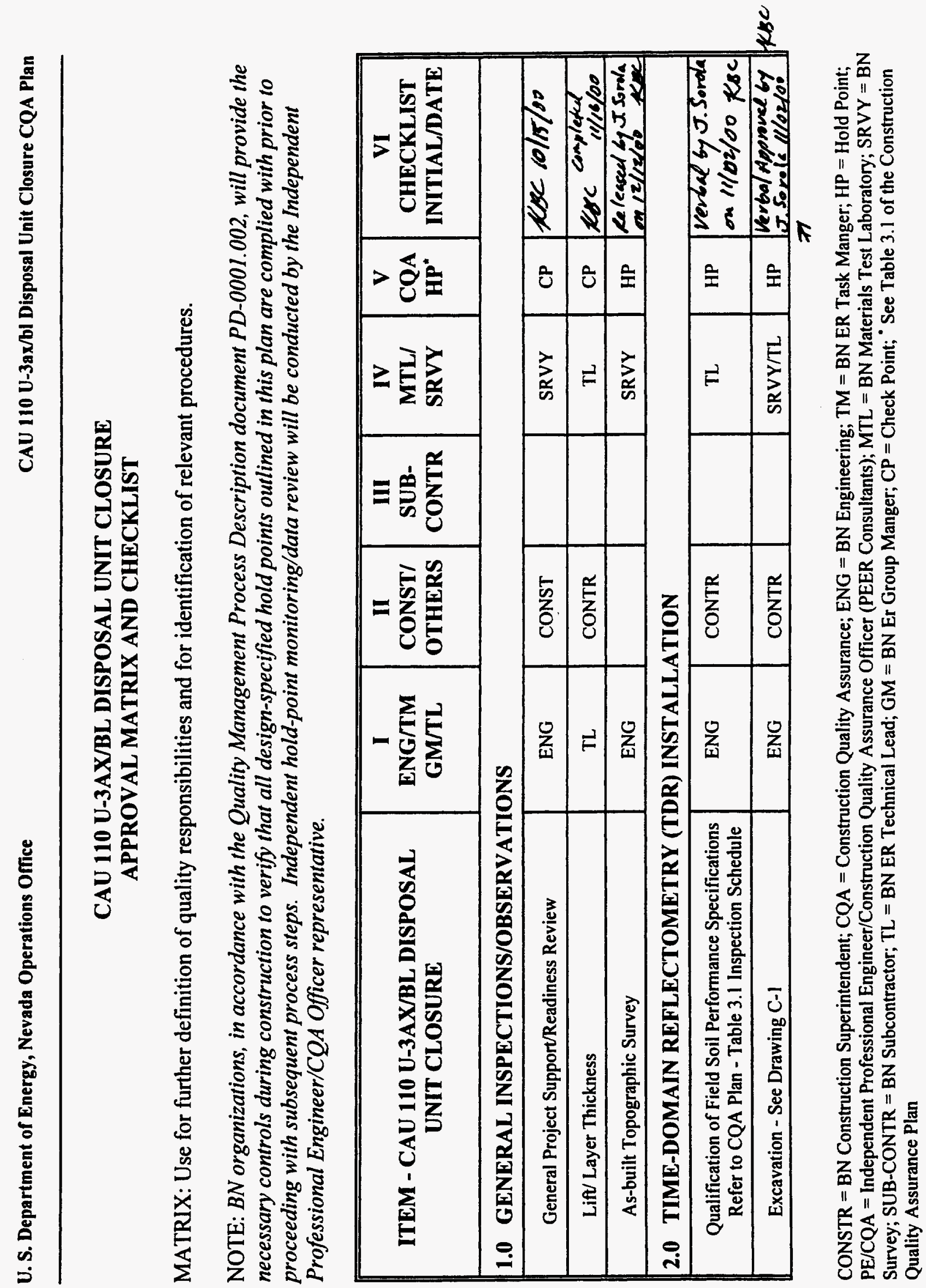




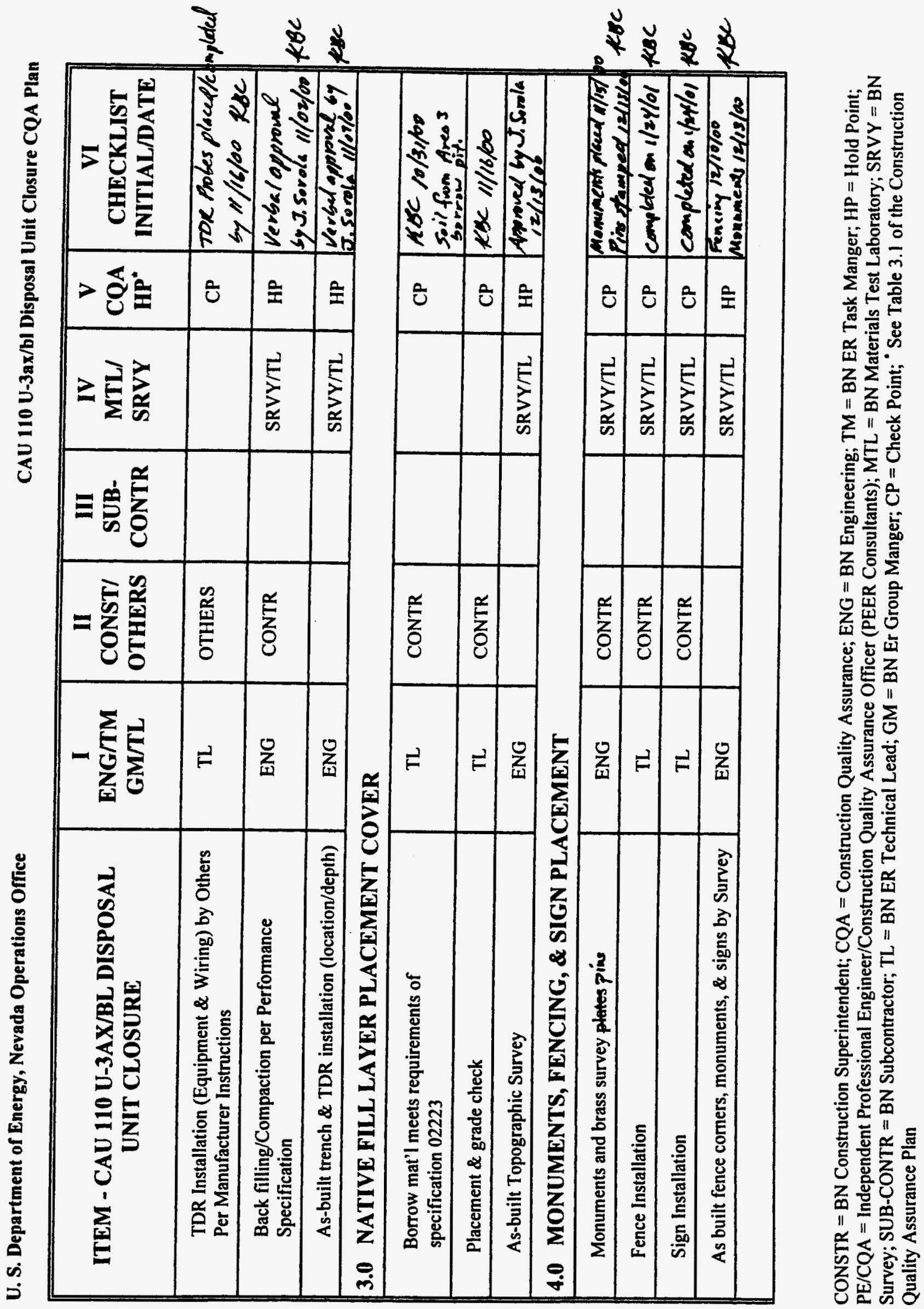



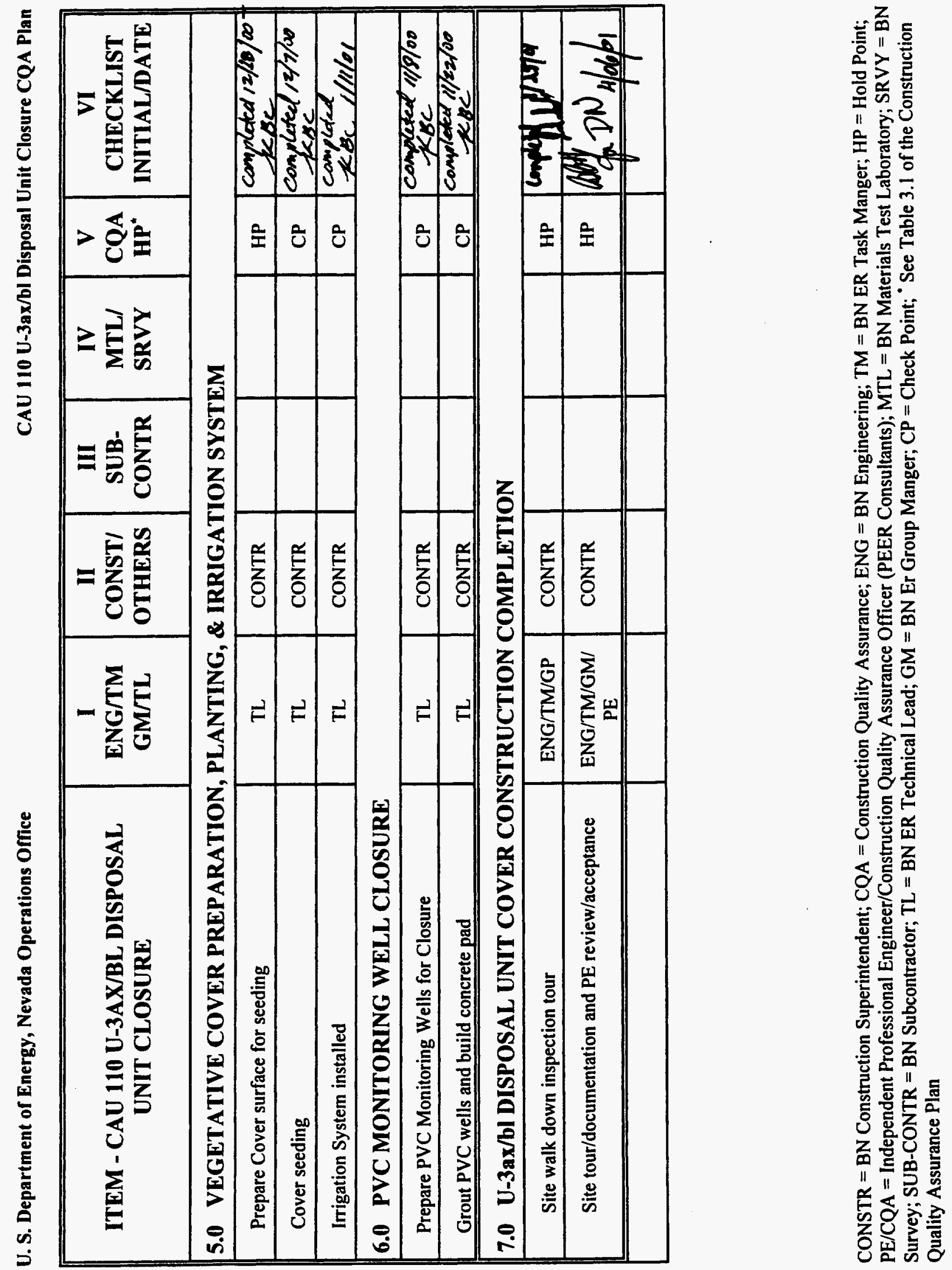
Closure Repor - CAL: 110

Section: Appendix B

Revision: I

Date August 6. 2001

4

a

?

THIS PAGE INTENTIONALLY LEFT BLANK

$-$ 
Closure Repor - CAU 110

Section: Appendix C

Revision: 1

Date. August 6. 2001

\section{APPENDIX C TESTING/INSPECTION REPORTS}


Closure Repon - CAL 110

Section Appendix $C$

Revision: 1

Date: August 6. 2001

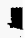

$0^{2}$

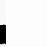

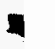

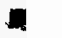

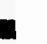

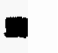

- 
NUCLEAR DENSTAY A57M 02922.96

CAMPBEU MC-2NG-3 TROXLER

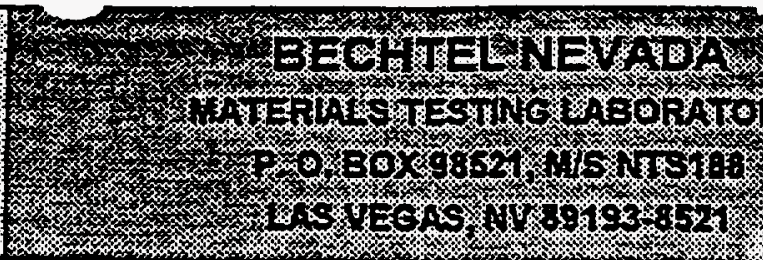

CHARGE:

C7KO9D1

DATETMPED

11010200

PAGE 1 OF 1

\begin{tabular}{|c|c|c|c|c|c|c|}
\hline Requested by & \multirow{3}{*}{ User/Agency } & \multirow{3}{*}{$\begin{array}{r}\text { - BECHTEL } \\
\text { Location } \\
10 / 31 / 2000 \\
\end{array}$} & \multirow{3}{*}{$\begin{array}{l}\text { Material } \\
\text { n of Tests } \\
\text { Checked by }\end{array}$} & \multicolumn{3}{|c|}{ PROCTOR, LAB \# 0262, TP21 (11/09R } \\
\hline $\begin{array}{l}\text { Requested by } \\
\text { Project } \\
\text { Tested by }\end{array}$ & & & & \multicolumn{3}{|c|}{ TEST PIT } \\
\hline Tested by & & & & & & \\
\hline LABORATORY NO & 139 & 140 & 141 & 142 & 143 & $144^{\circ}$ \\
\hline DEPTH OF PROBE & $10^{n}$ & $10^{n}$ & $10^{n}$ & $12^{n}$ & $12^{n}$ & $12^{\prime \prime}$ \\
\hline DEPTH OF TESTS & 1 & 1 & 1 & 2 & 2 & 2 \\
\hline TEST \# & 1 & 2 & 3 & 4 & 5 & 6 \\
\hline DRY DENSITY-PCF & 90.1 & 93.9 & 91.1 & 94.5 & 93.4 & 91.9 \\
\hline MOISTURE \% & 8.4 & 7.6 & 8.5 & 7.6 & 7.0 & 7.5 \\
\hline PERCENT COMPACTION & 79.1 & 82.4 & 80.0 & 83.0 & 82.0 & 80.7 \\
\hline MAX DENSITY PCF & 113.9 & 113.9 & 113.9 & 113.9 & 113.9 & 113.9 \\
\hline OPTIMUM MOISTURE \% & 12.9 & 12.9 & 12.9 & 12.9 & 12.9 & 12.9 \\
\hline REQUIRED COMPACTION \% & 80.0 & 80.0 & 80.0 & 80.0 & 80.0 & 80.0 \\
\hline IN / OUT OF SPECIFICATION & OUT & $\mathbb{N}$ & IN & $\mathbb{N}$ & IN & IN \\
\hline
\end{tabular}

GAUGE NO

23205

DATE OF STANDARDIRATION 10/31/2000

VALUE OF $M$

031 STANDARDIZATION D

2814

PLOT PLAN

$\begin{array}{ccc}x & x & x \\ 1 \& 4 & 2 \& 5 & 3 \& 6\end{array}$

REMARKS: TEST PIT WAS APPROXMMATEI Y 6X3' BY 3' DEEP. 1AT LIFT PLACED WAS ABOUT 10" AND THE 2ND ABOUT 12" TFICK RETEST OF TEST \#1 WAS NOT NEEDED BYK CAMPBEILI.
CC: J. SOROLA

\begin{tabular}{ll}
\hline G. HUDAK & BECHTEL \\
\hline J. SMITH & PEER \\
\hline D. MAOSEN & BECHTEL \\
\hline K CAMPBELL & BECHTEL \\
\hline MTL BECHTEL FILES & BECHTEL \\
\hline
\end{tabular}


Closure Report - CALi 110

Section: Appendix $C$

Revision 1

Date: August 6. 2001

\section{THIS PAGE INTENTIONALLY LEFT BLANK}


Closure Report - CAL: 110

Section Appendix D

Revision: 1

Date: August 6. 2001

\section{APPENDIX D VEGETATION SPECIES LIST}


Closure Repon - CAl:110

Section: Appendix D

Revision 1

Date: August 6. 2001

THIS PAGE INTENTIONALLY LEFT BLANK 


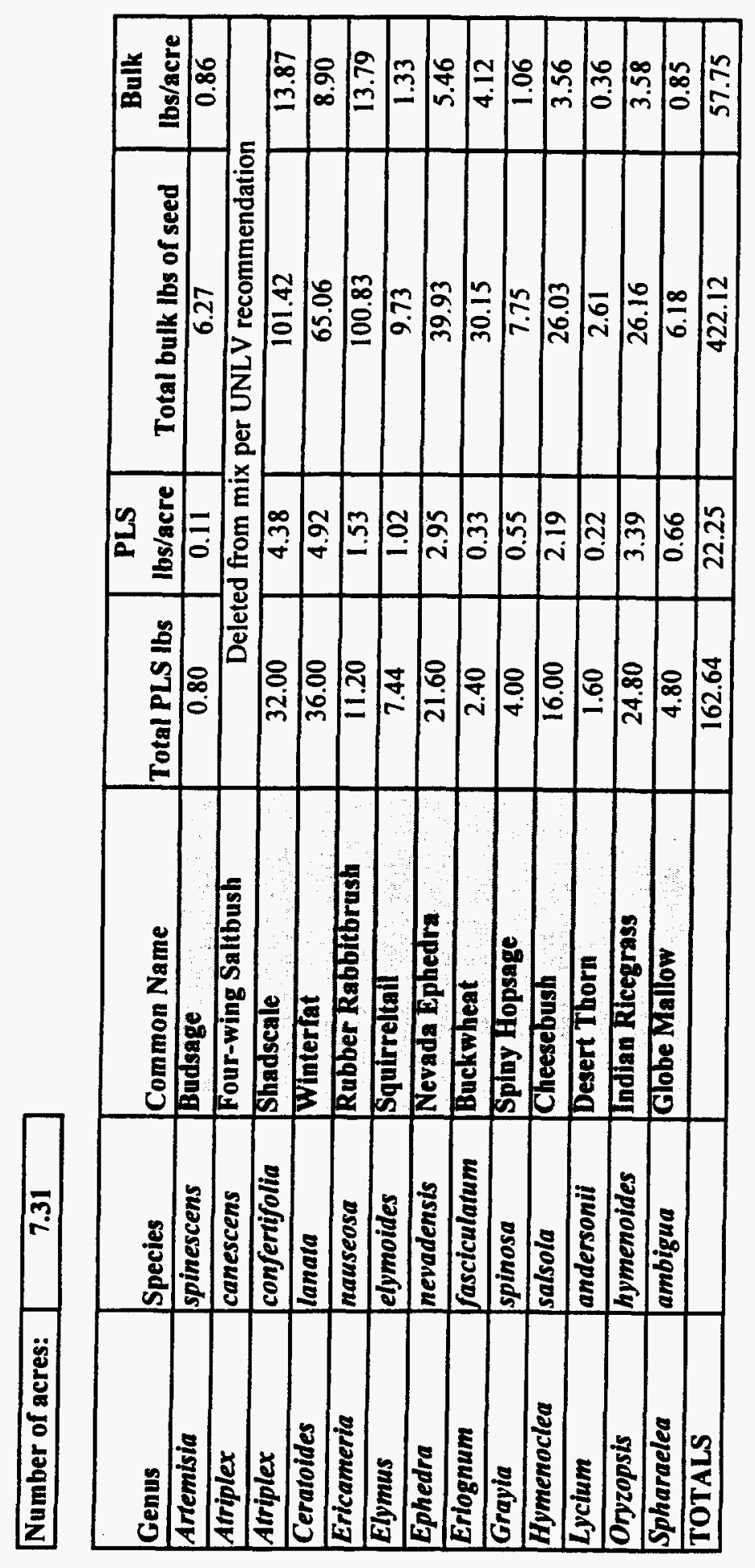


Closure Repon - CAL 110

Section Appendix D

Revision: I

Date: August 6. 2001

THIS PAGE INTENTIONALLY LEFT BLANK

E 
Closure Report - CAll 110

Section: Appendix $E$

Revision: 1

Date: August 6. 2001

\section{APPENDIX E DEVIATIONS FROM CONSTRUCTION QAP}


Closure Repor - CAl: 110 Section. Appendix $E$

Revision: 1

Date: August 6. 2001

na 


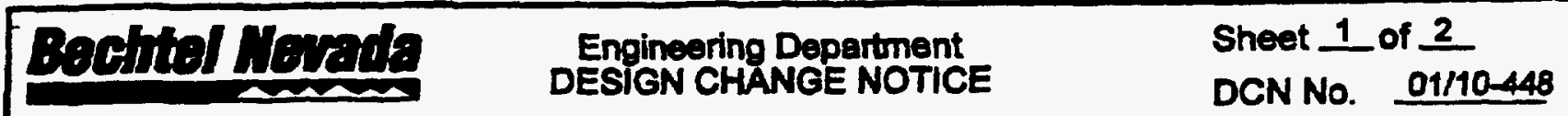

国 Design Drawing $\quad \square$ Deaign Spectication $\quad$ Dato Intiated: 10/31/00

Document No.: JS-003-00004-C3

Roviaion No: 0

THa: SECTIONS

Description of Change:

MODIFIED SECTION C

Engineering Tracking No. $00004 . A 03$

1

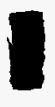

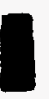

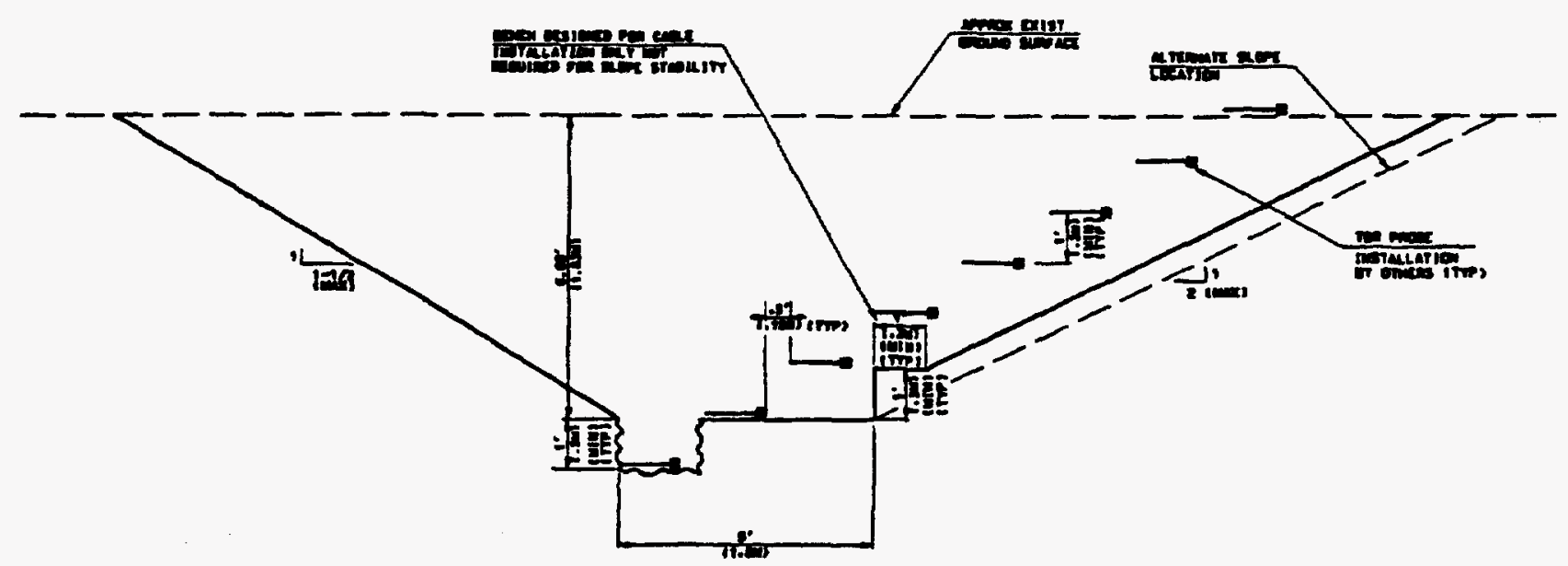

SECTION

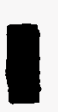

section

(c).

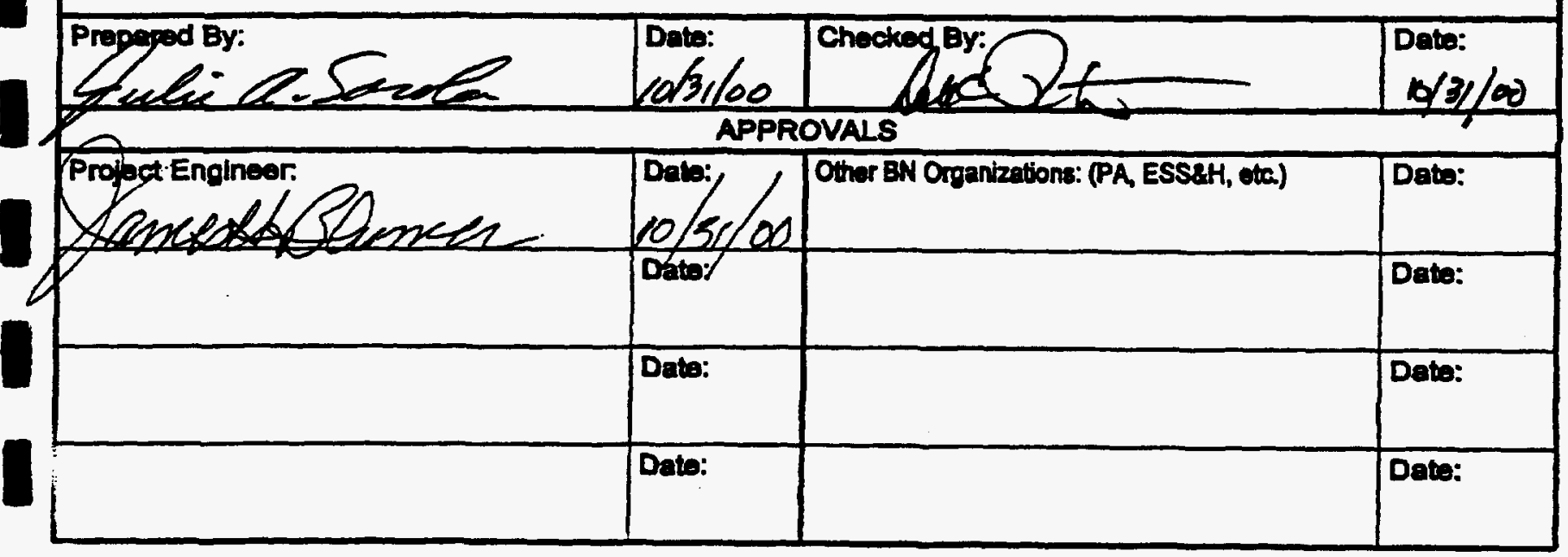




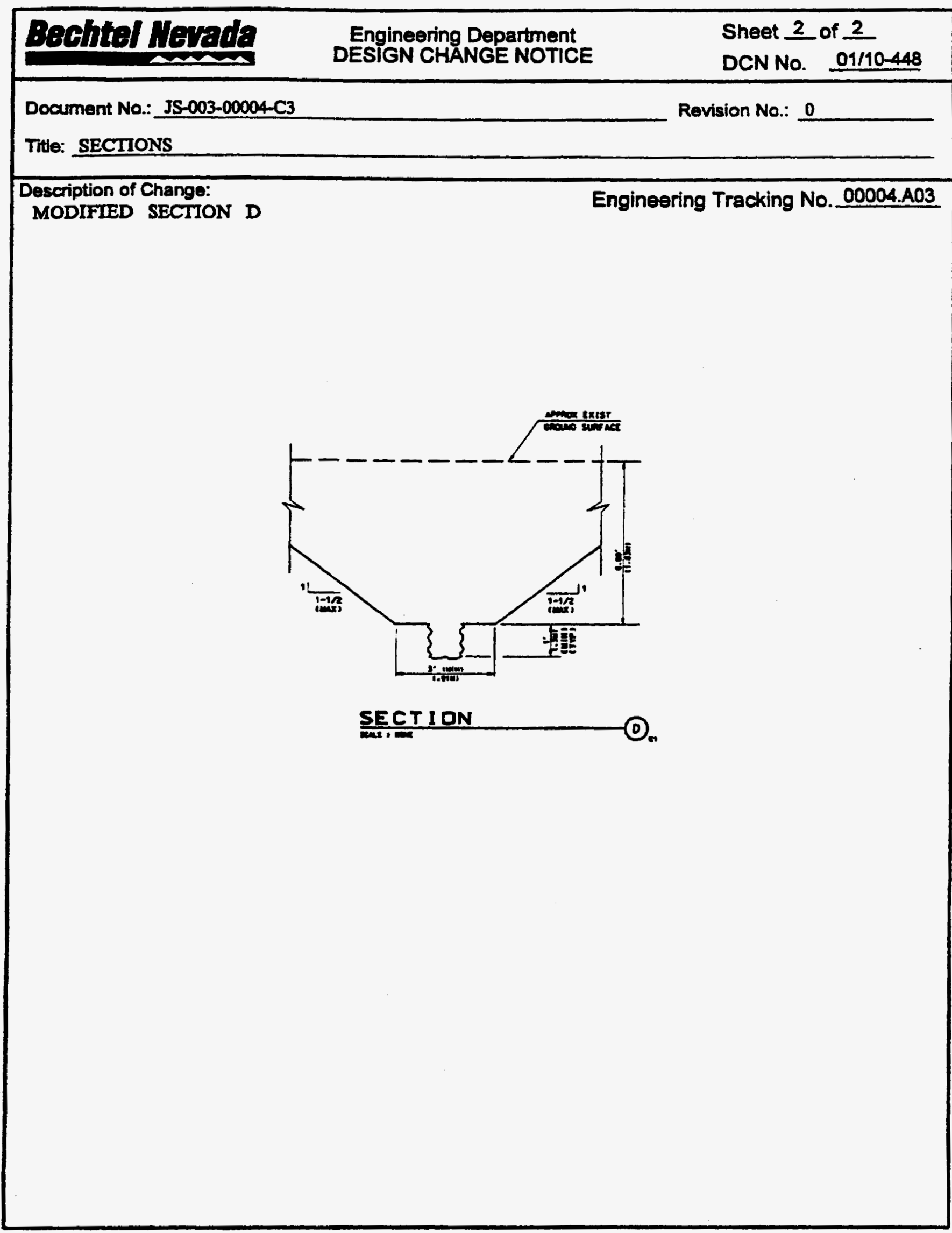




\section{Bechtel Nevada}

$\square$ Design Drawing

Document No.:
Engineering Department DESIGN CHANGE NOTICE
Sheet

1

of

DCN No.: DCN01/10-449
区Design Speclfication SP-00004A03-C0007
Date Initiated:

Revision No.:
$10 / 31 / 2000$

Title: Construction Specifications for U3ax/bl RCRA Equivalent Closure

\section{Description of Change:}

SECTION 02222, PART 3, PARAGRAPH 3.03.D.2.C:

REPLACE Minimum area to be tested shall be 3 feet $(914 \mathrm{~mm})$ by 16 feet $(4.88 \mathrm{~m})$. WITH Minimum area to be tested shall be 3 feet $(914 \mathrm{~mm})$ by 6 feet $(1.83 \mathrm{~m})$.

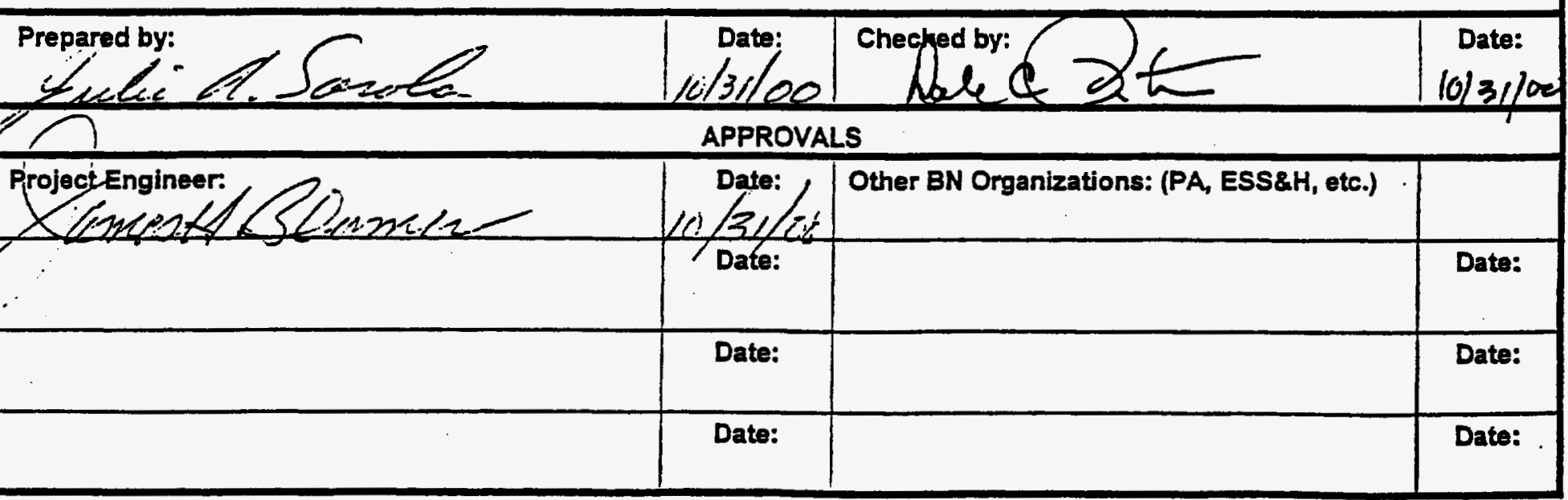


$\begin{array}{ll}\text { From: } & \text { Julie Sorola } \\ \text { To: } & \text { ENVIRON.MERC-DORMB.CampbeK } \\ \text { Date: } & 11 / 9 / 009: 15 a m \\ \text { Subject: } & \text { Re: Ax/bl fence engineering tech change request and TDR data -Reply }\end{array}$

Kevin,

The proposed fence reconfiguration is acceptable. A DCN will be issued that will delete the requirement to reinstall the existing rad fence after construction of the cover and move the new fence to the approximate location of the existing rad fence. Per our conversation, the new fence will be signed as a radiation contamination area in addition to the required RCRA postings.

Please supply information on the new postings for inclusion in the asbuilt package i.e., spacing, size, color, wording, etc. I know these postings are standard for the NTS, but we do not have that information in engineering.

cc:

HUDAKGG, ENVIRON.MERC-DORMB.MADSENDD, ENVIRON.MERC... 
Closure Report - CAU 110

Section: Appendix F

Revision: 1

Date: August 6. 2001

\section{APPENDIX F \\ “AS-BUILT" DRAWINGS FOR AREA 3 U-3AX/BL COVER}


Closure Repon - CAU 110 Section: Appendix F

Revision: 1

Dale: August 6. 2001
10

THIS PAGE INTENTIONALLY LEFT BLANK 


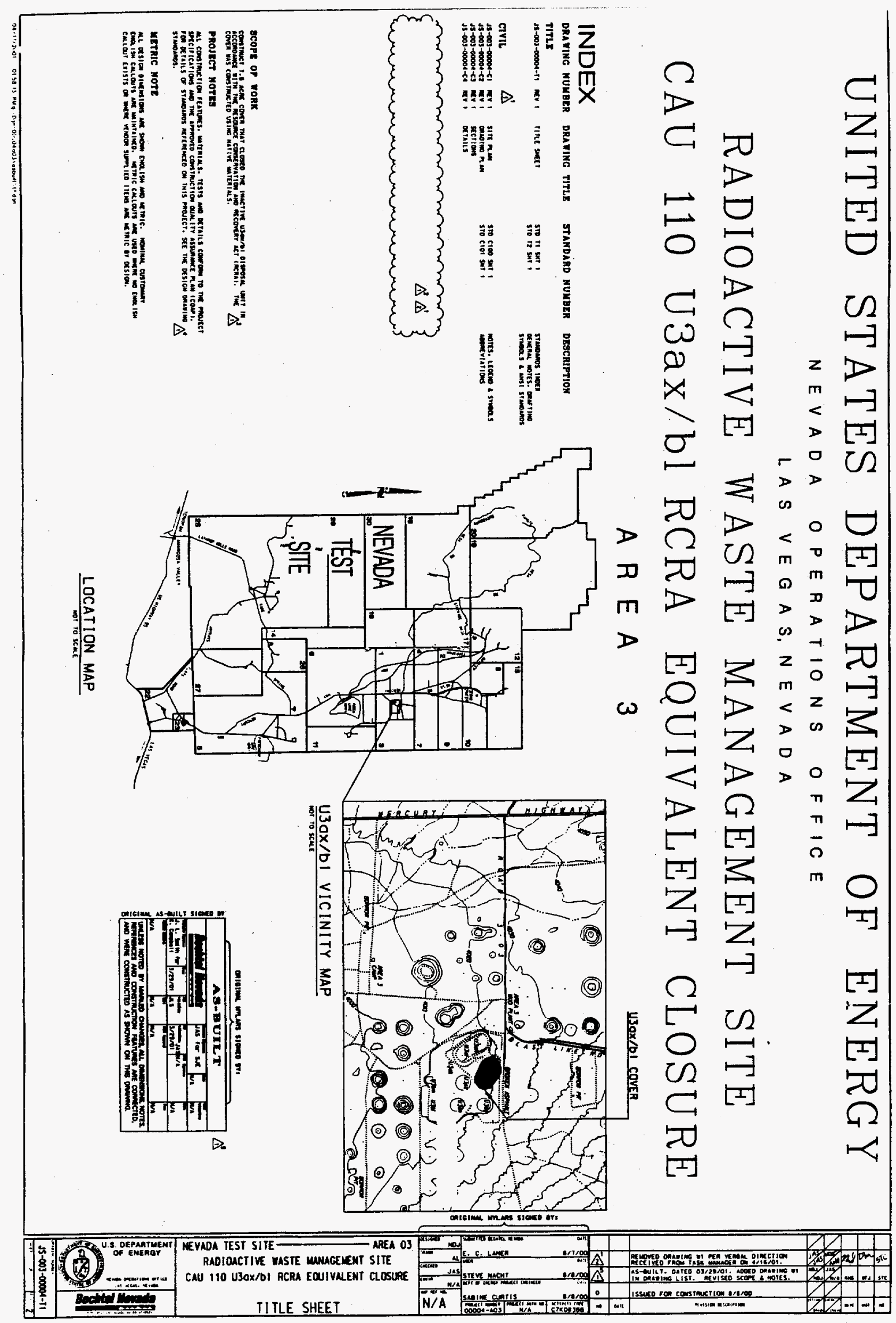



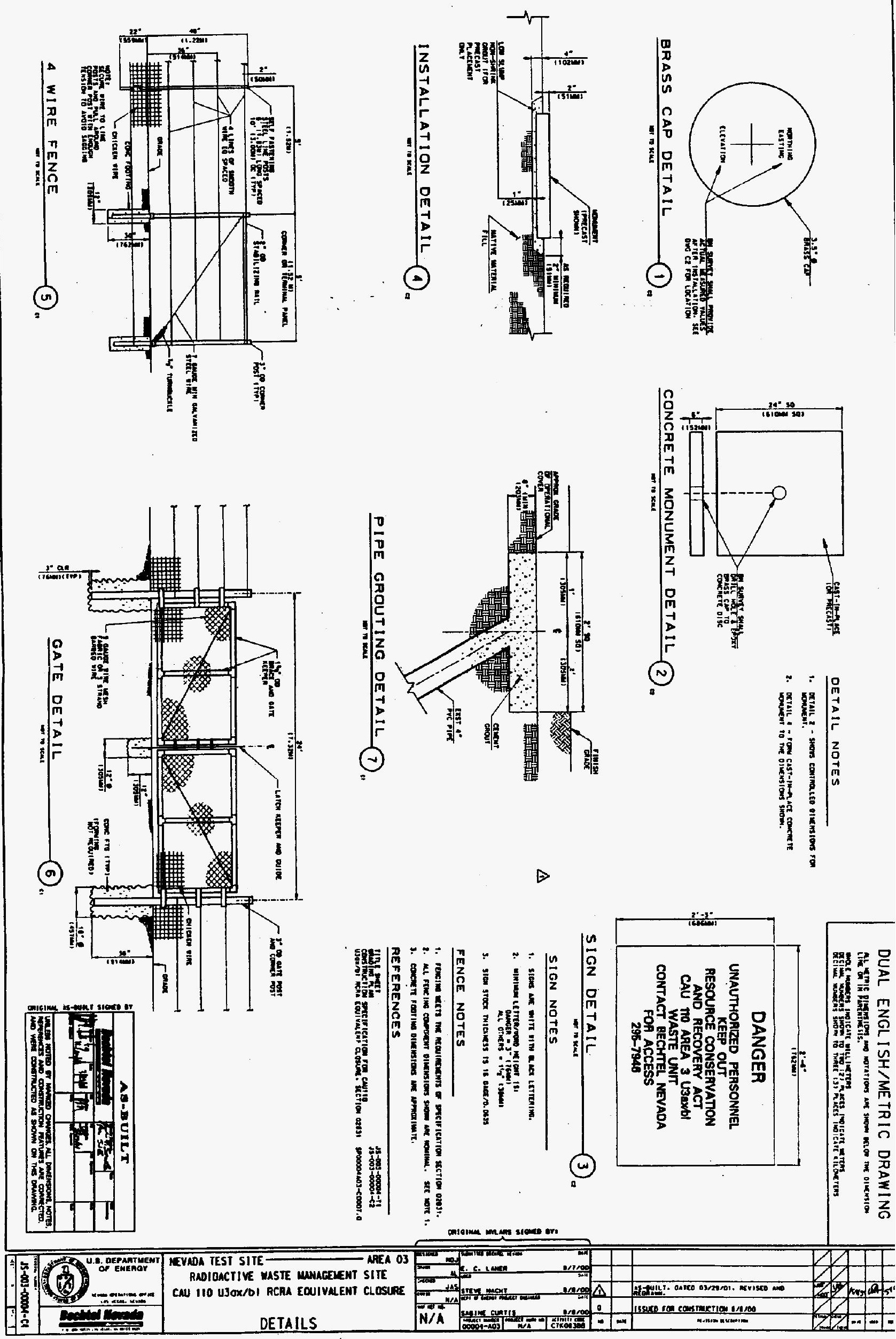


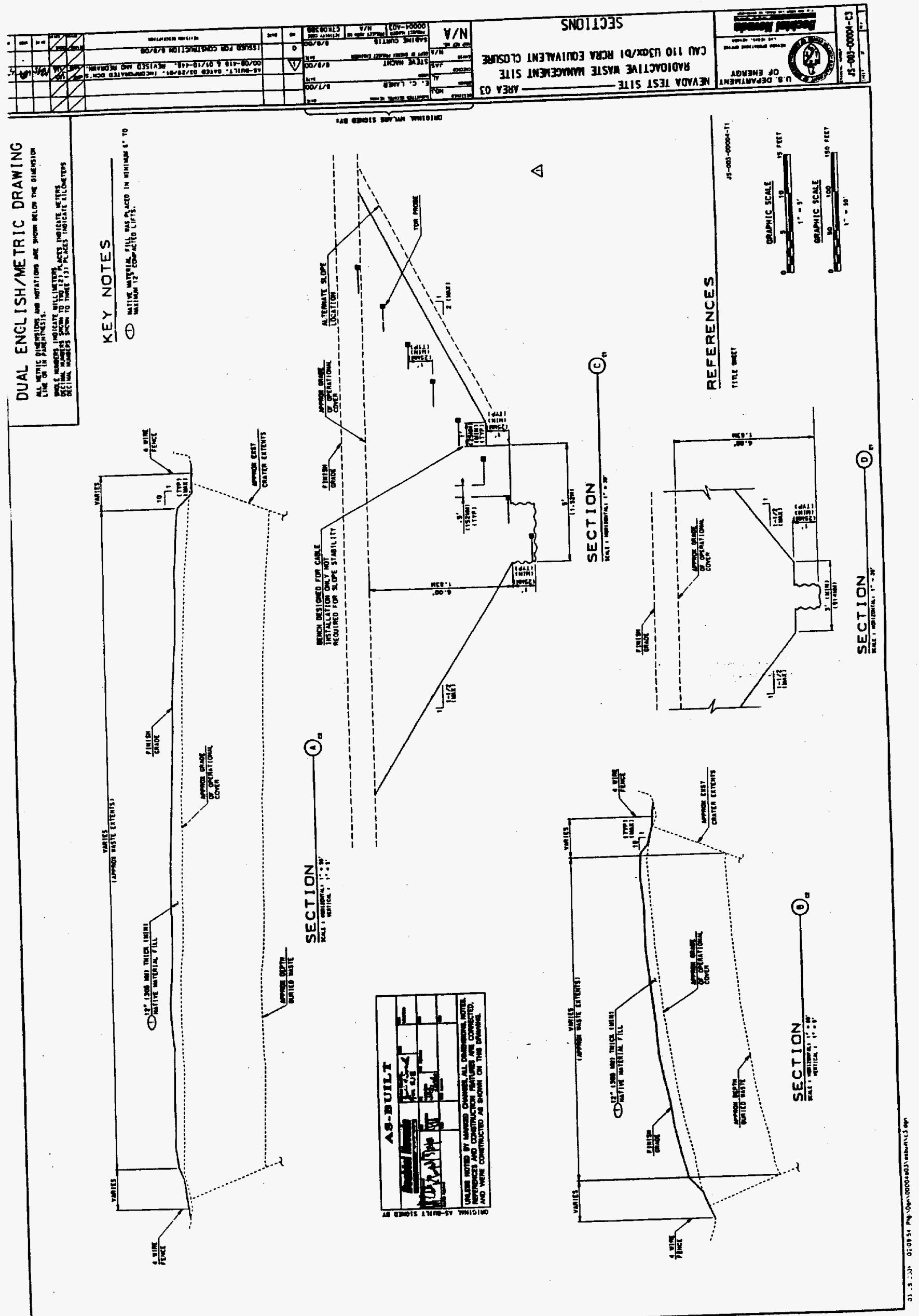




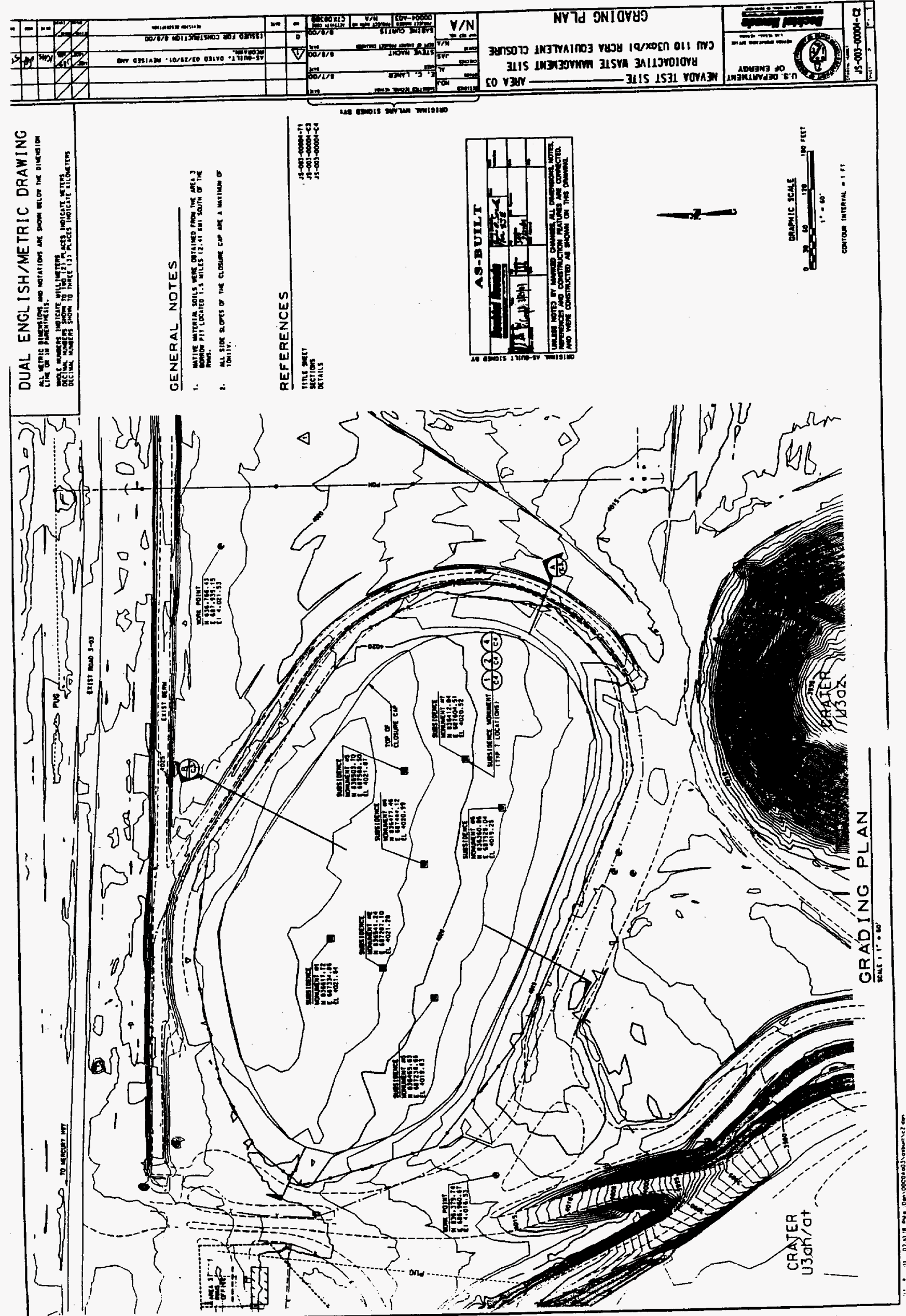



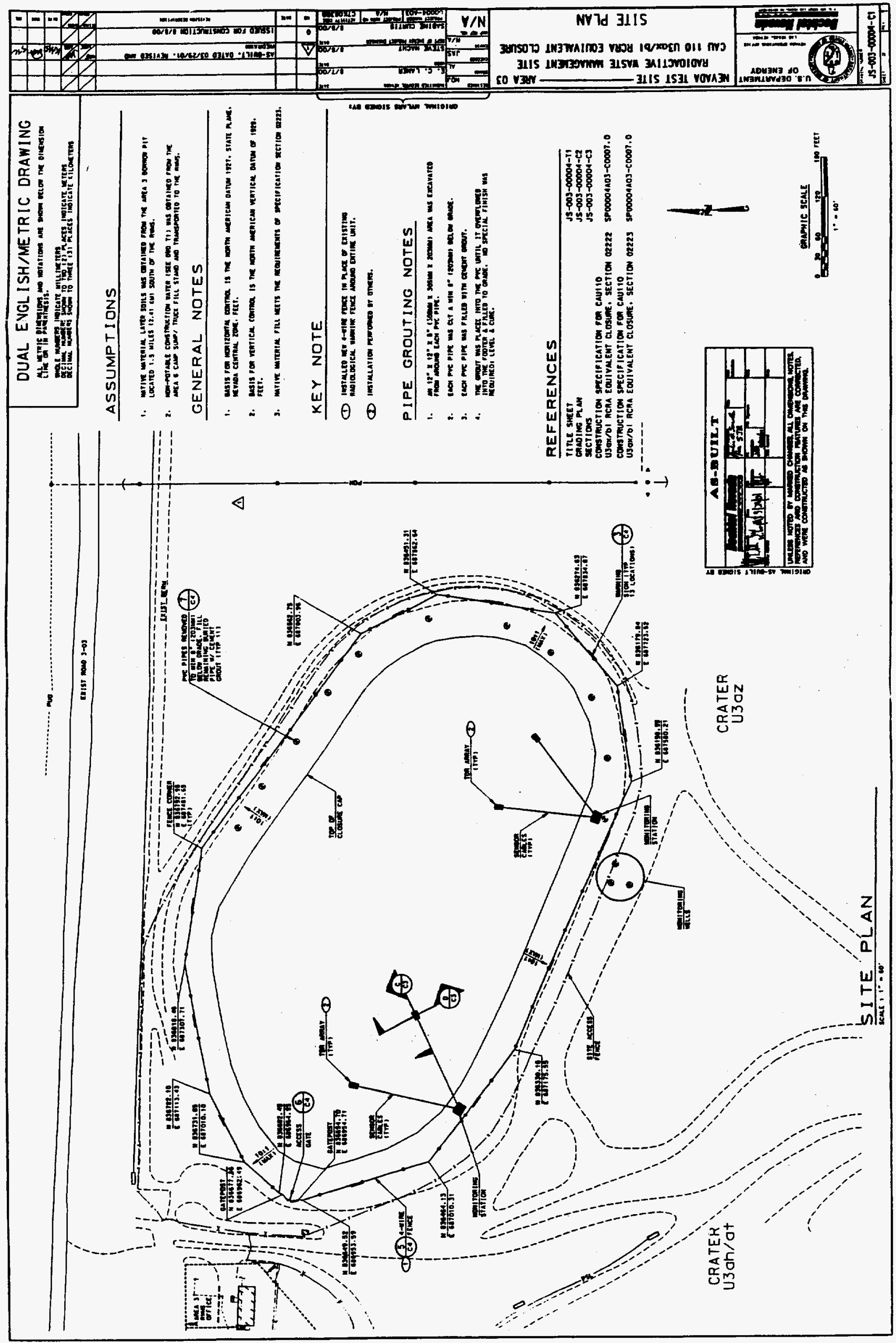
Closure Report - CAL! 110

Section: Appendix G

Revision: I

Date: August 6.2001

\section{APPENDIX G LAND-USE RESTRICTIONS}


Closure Report - CALi 110 Section: Appendix G

Revision: 1

Date: August 6. 2001 


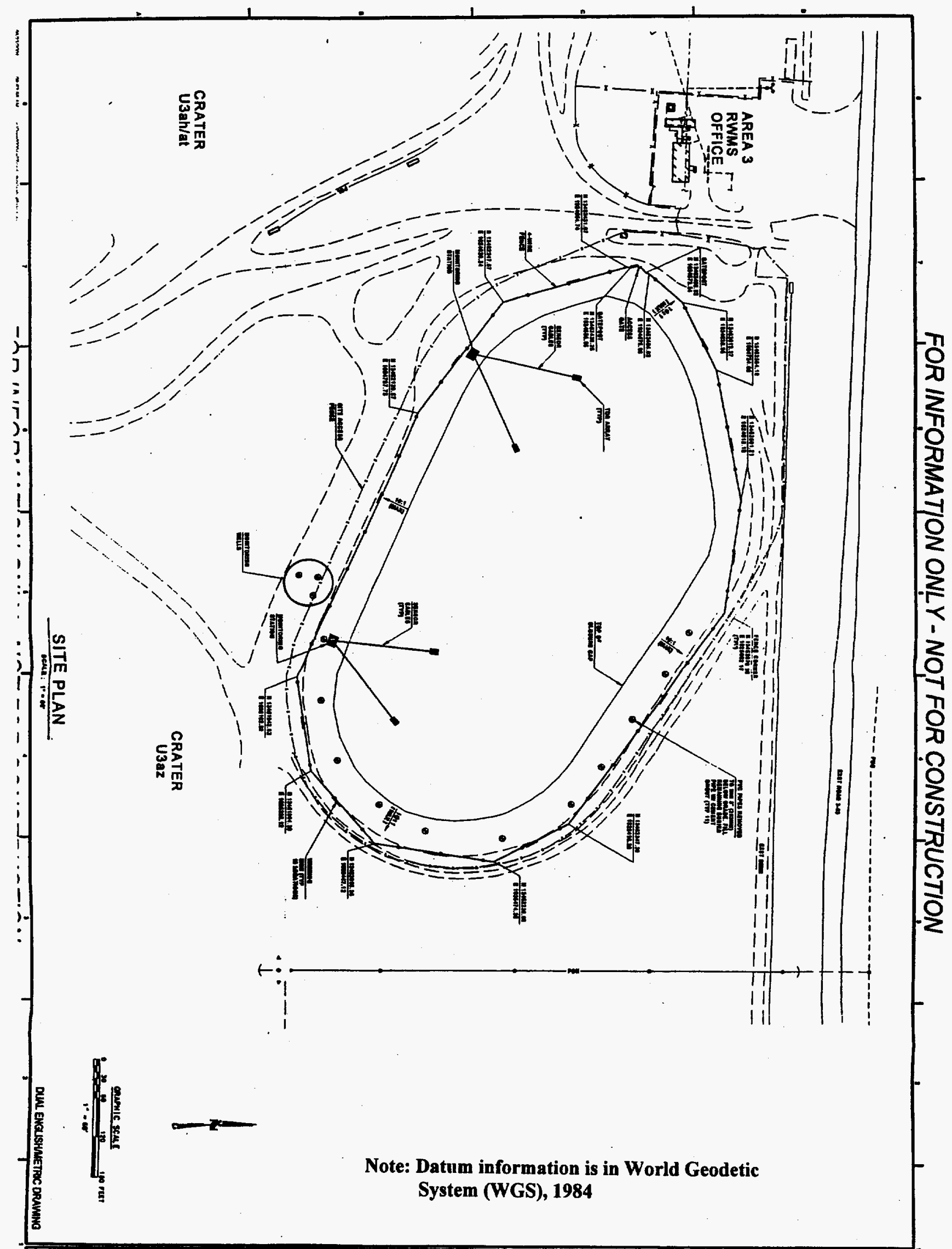

RADIOACTIVE WASTE YANAGENENT BITE

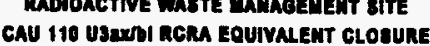

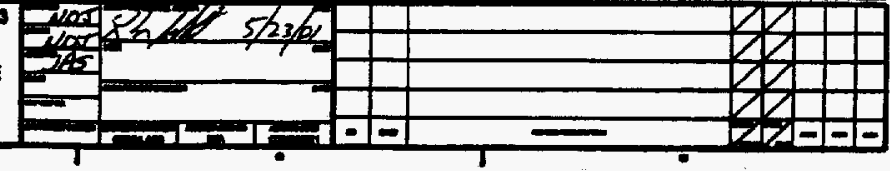


Closure Repor - CAL 110

Section. Appendix $G$

Revision: 1

Date: August 6.2001

\section{APPENDIX G LAND-USE RESTRICTIONS}


Closure Repon - CALI 110

Section: Appendix G

Revision: 1

Date: August 6. 2001

THIS PAGE INTENTIONALLY LEFT BLANK 


\section{CAU Use Restriction Information}

CAU Number/Description: CAU 110: Area 3 WMD U-3ax/bl Crater

Applicable CAS Numbers/Descriptions: CAS 03-23-04: U-3ax/bI Subsidence Crater

Contact (Organization/project): DOE/NV Industrial Sites Project Manager

Surveyed Area (UTM coordinates; Zone 11, NAD 27): The site is defined by the following

NAD 27 coordinates: Gatepost: 13,452,458.93 N; 1,924,573.54 E Southern end of cover:

13,452,059.38 $\mathrm{N} ; 1,925,447.12 \mathrm{E}$ - Northeast side: $13,452,601.21 \mathrm{~N} ; 1,924,918.18 \mathrm{E}-$

$13,452,578.35 \mathrm{~N} ; 1,925,092.17 \mathrm{E}-13,452,347.30 \mathrm{~N} ; 1,925,415.20 \mathrm{E}-13,452,236.09 \mathrm{~N}$

$1,925,474.25$ and Southwest side: $13,452,247.57 \mathrm{~N} ; 1,924,620.24 \mathrm{E}-13,451,942.82 \mathrm{~N} ;$

$1,925,192.82 \mathrm{E}-13,451,964.20 \mathrm{~N} ; 1,925,336.12$

Survey Date: January 24, 2001 Survey Method (GPS, etc.): Transit Survey

Site Monitoring Requirements: Visual inspections, subsidence monitoring, \& TDR analysis

Required Frequency (quarterly, annually?): Varies, check Closure Plan for activity specific

frequency

If Monitoring Has Started, Indicate Last Completion Date: N/A

\section{Use Restrictions}

The future use of any land related to this Corrective Action Unit (CAU), as described by the above surveyed location, is restricted from any DOE or Air Force activity that may alter or modify the containment control as approved by the state and identified in the CAU Closure Report or other CAU documentation unless appropriate concurrence is obtained in advance.

Comments: See the Closure Report for additional information on the condition of the site and any monitoring and/or inspection requirements.

Submitted By: faret Opponslos-U)ing Date: $6 / 6 / 01$

cc with copy of survey map:

CAU Files ( 2 copies) 
Closure Repon - CALI 110 Secion: Appendix $G$

Revision: 1

Date: August 6. 2001

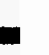

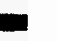

a

THIS PAGE INTENTIONALLY LEFT BLANK 
Closure Report - CAL 110

Section Appendix $\mathrm{H}$

Revision I

Date August 6. 2001

\section{APPENDIX H PHOTOGRAPHS AND FIELD NOTES}


Closure Repon - CAL' 110

Section Appendis $\mathrm{H}$

Revision: 1

Date: August 6. 2001

- 


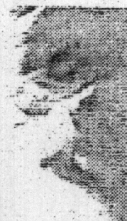

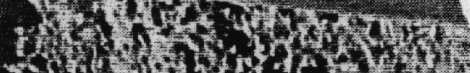

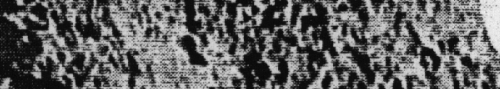

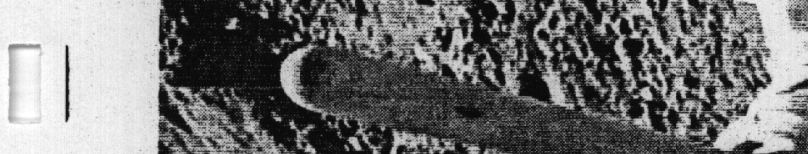

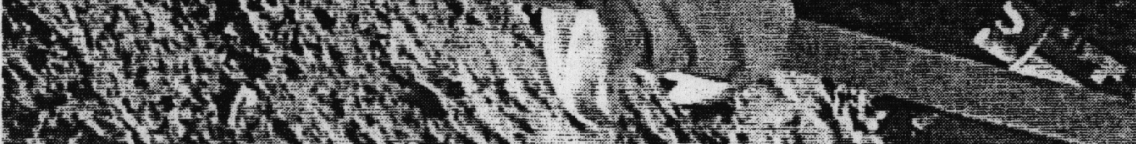

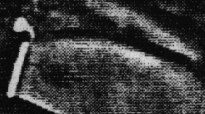

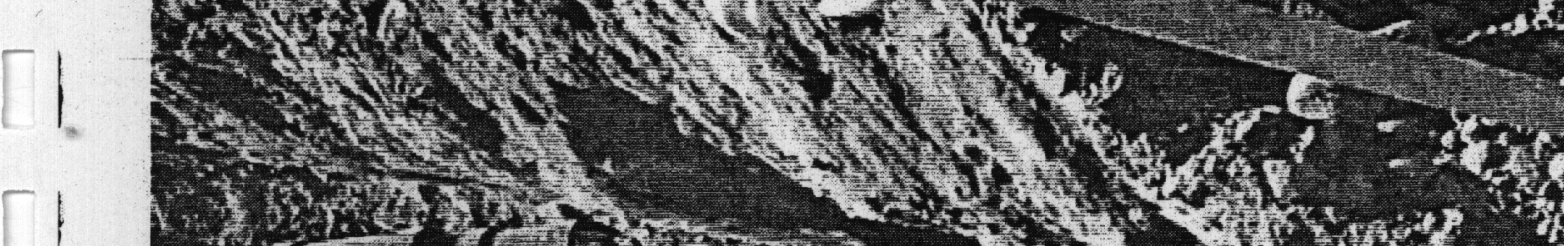

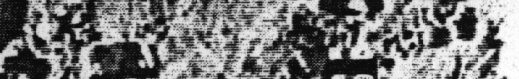

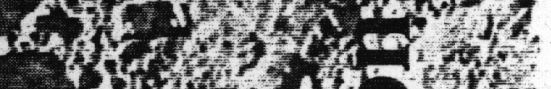

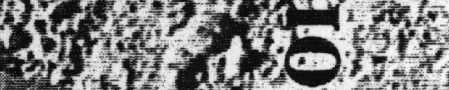
iffiniso

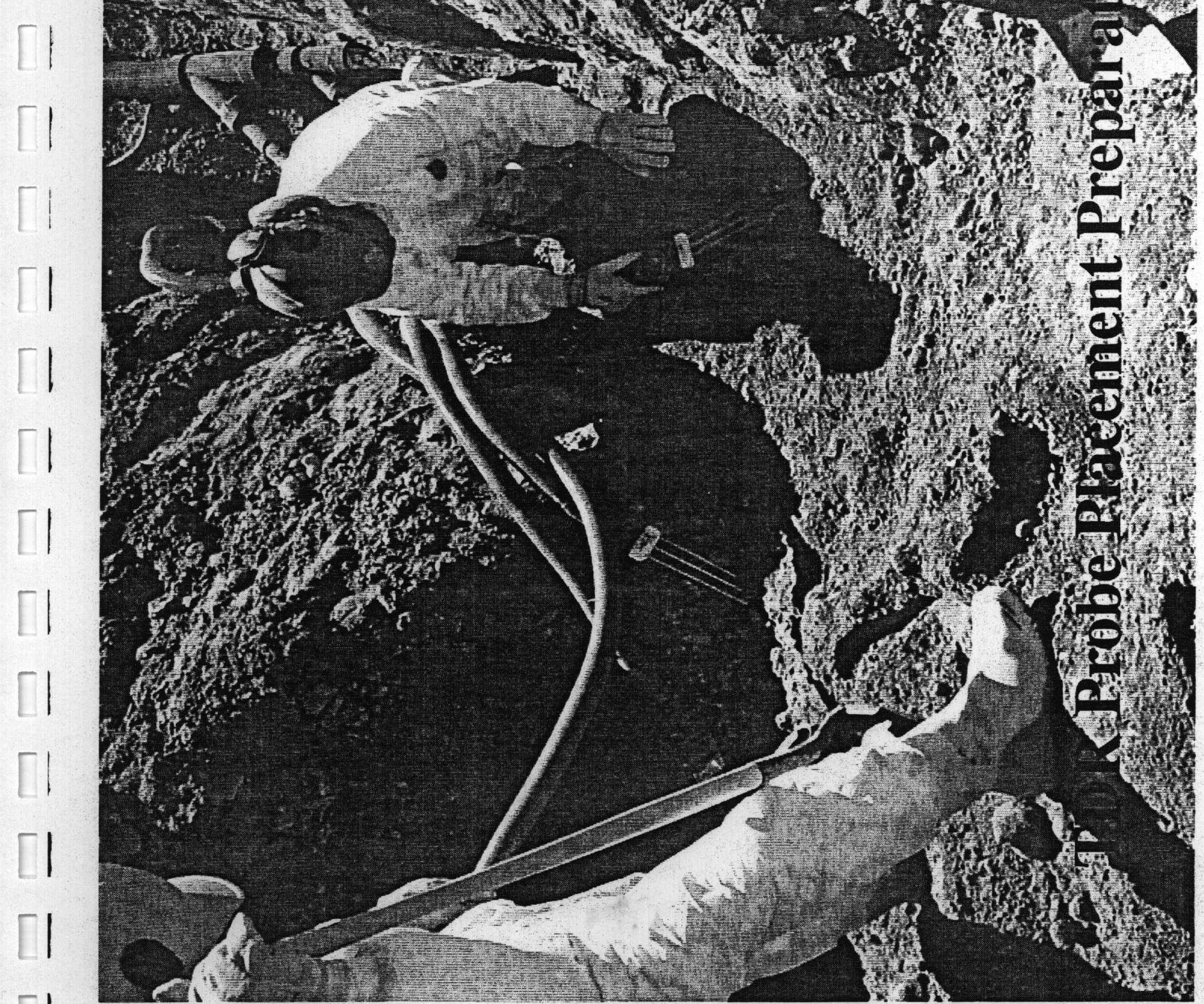




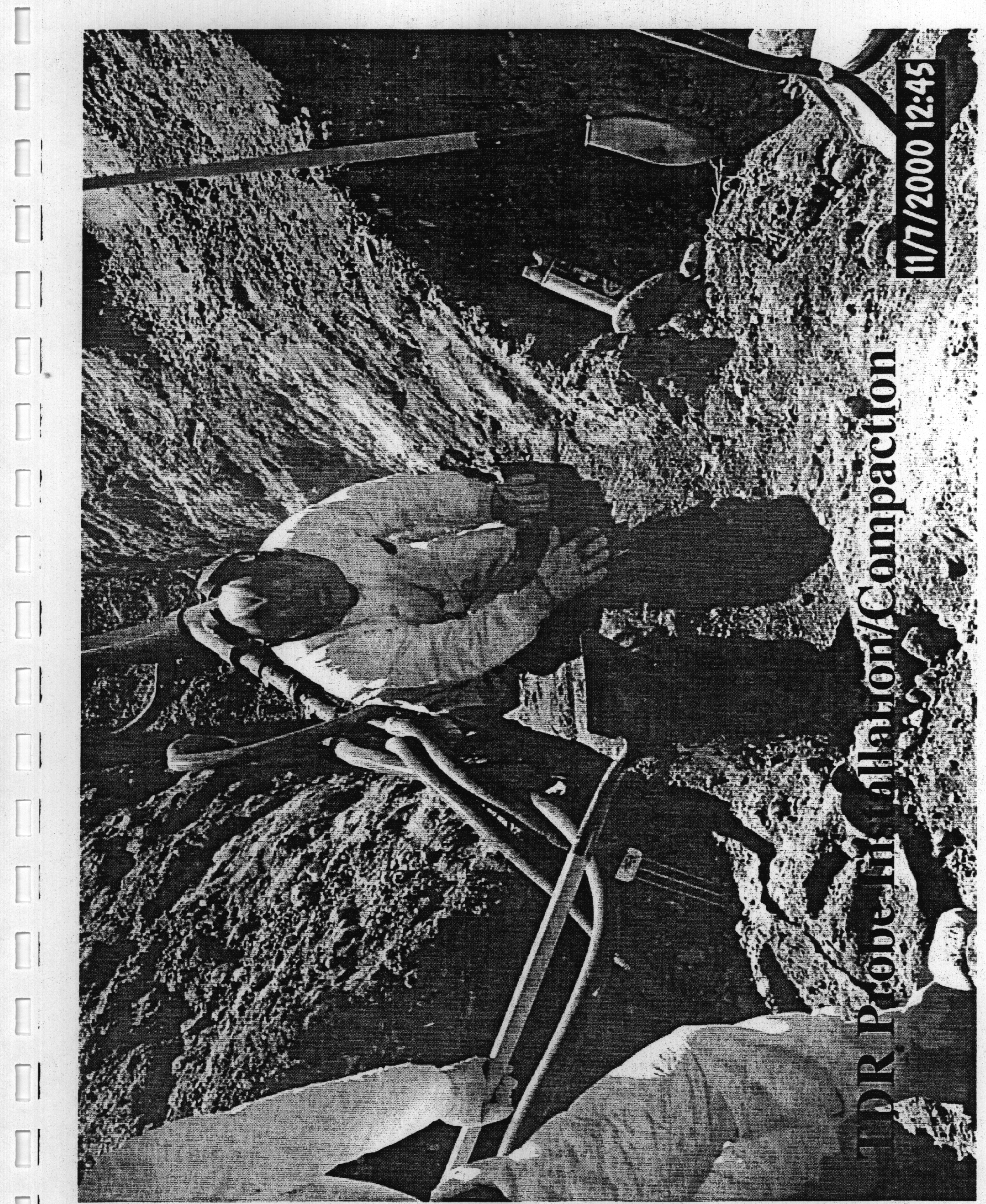




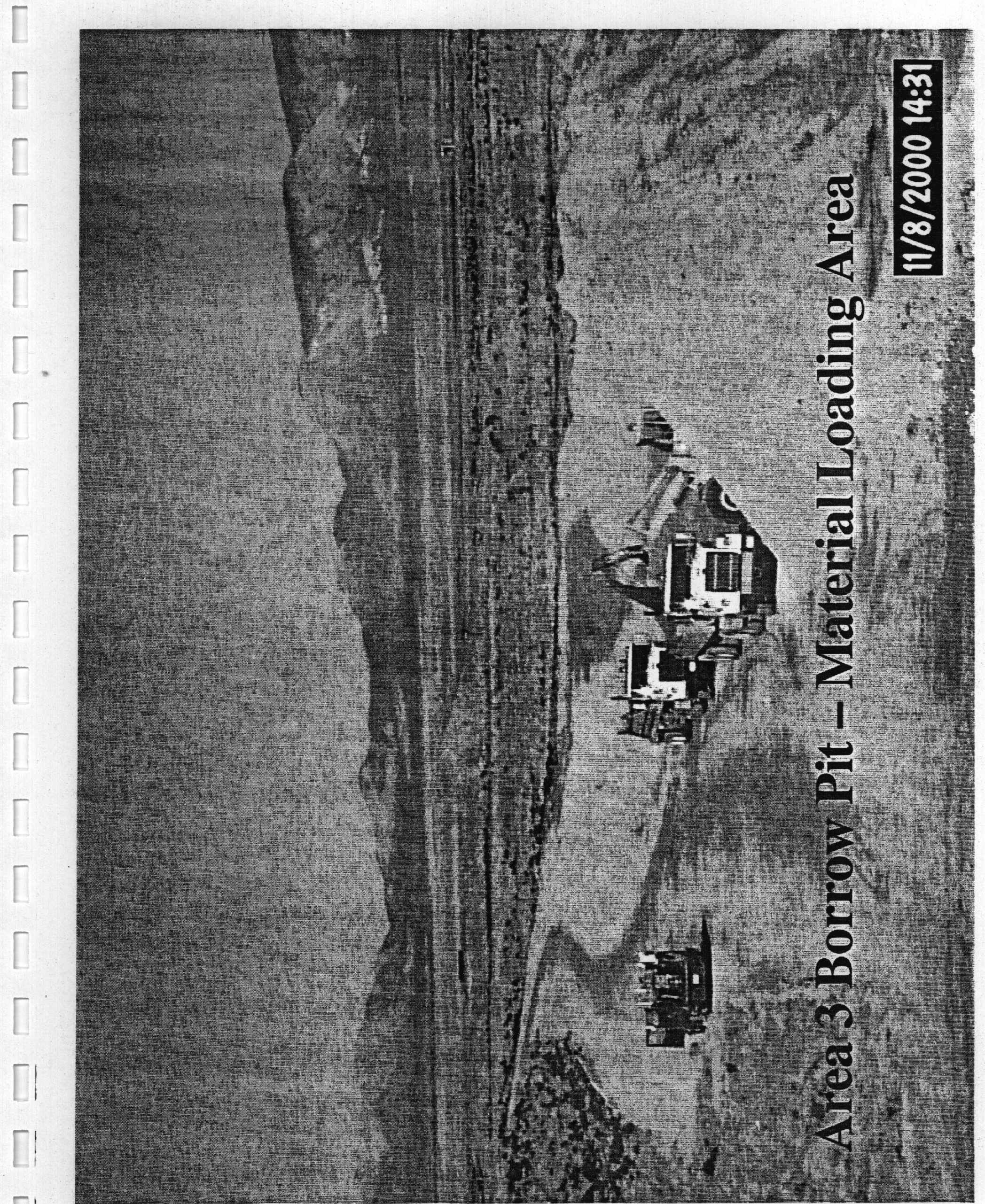




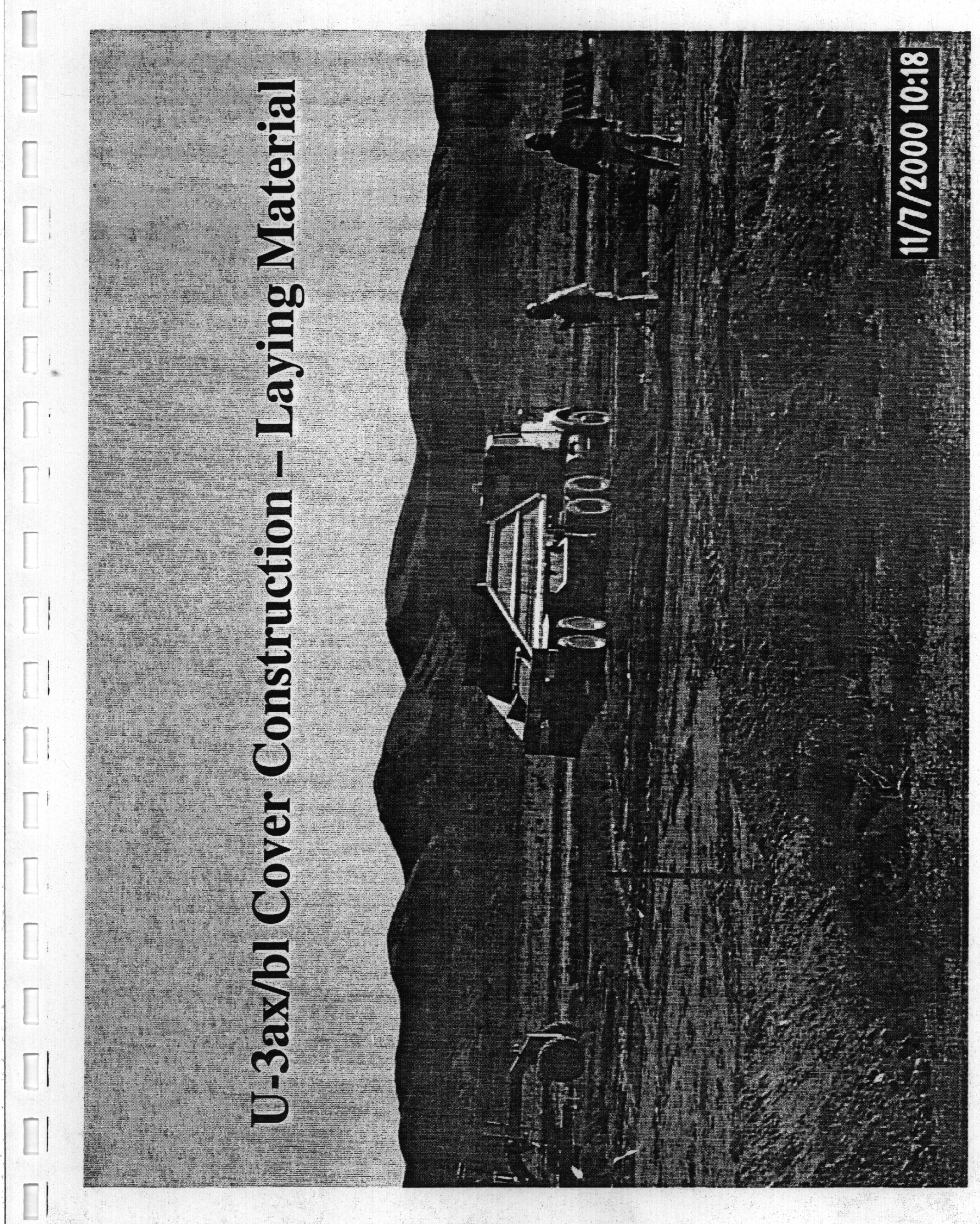




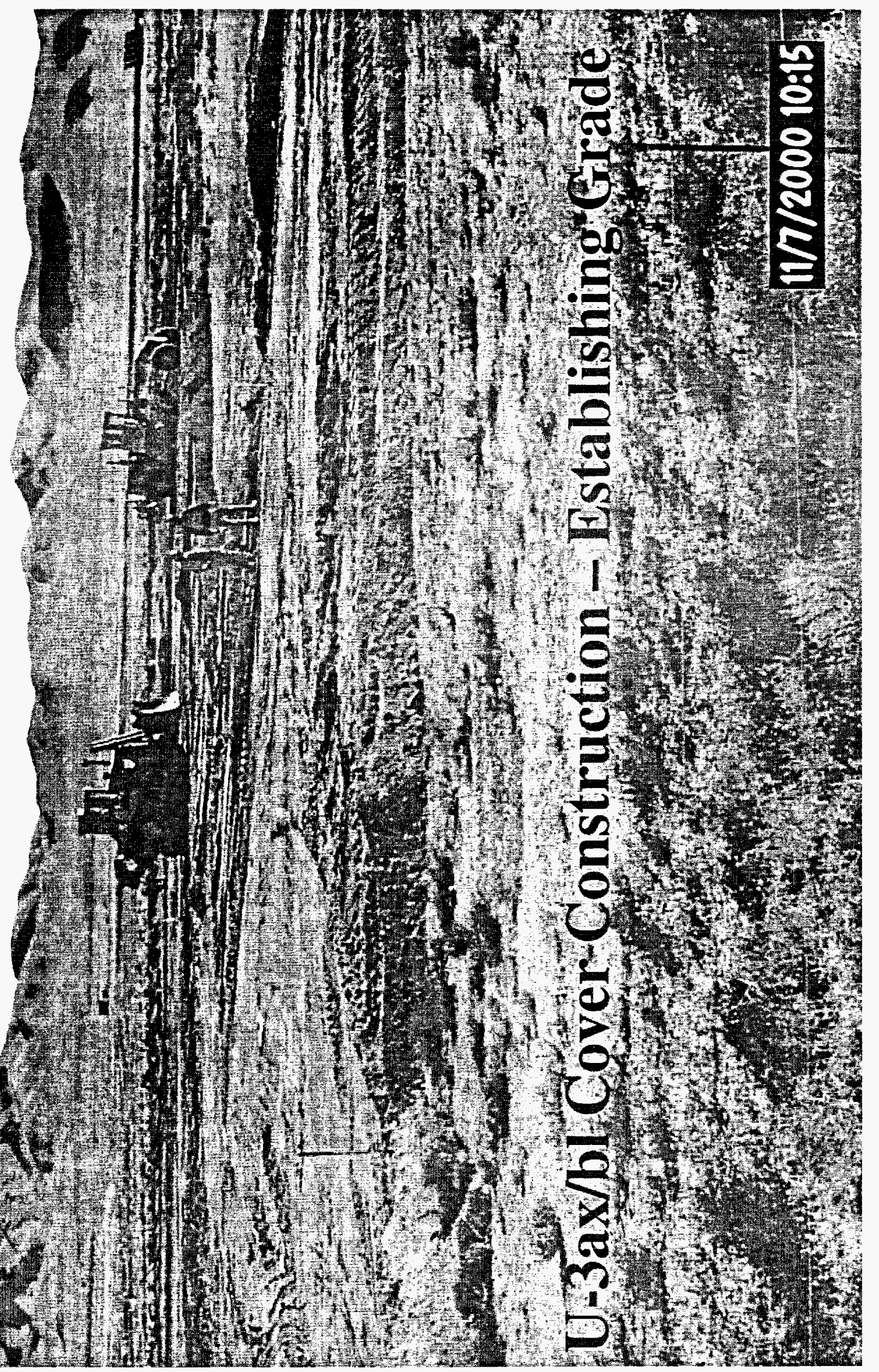




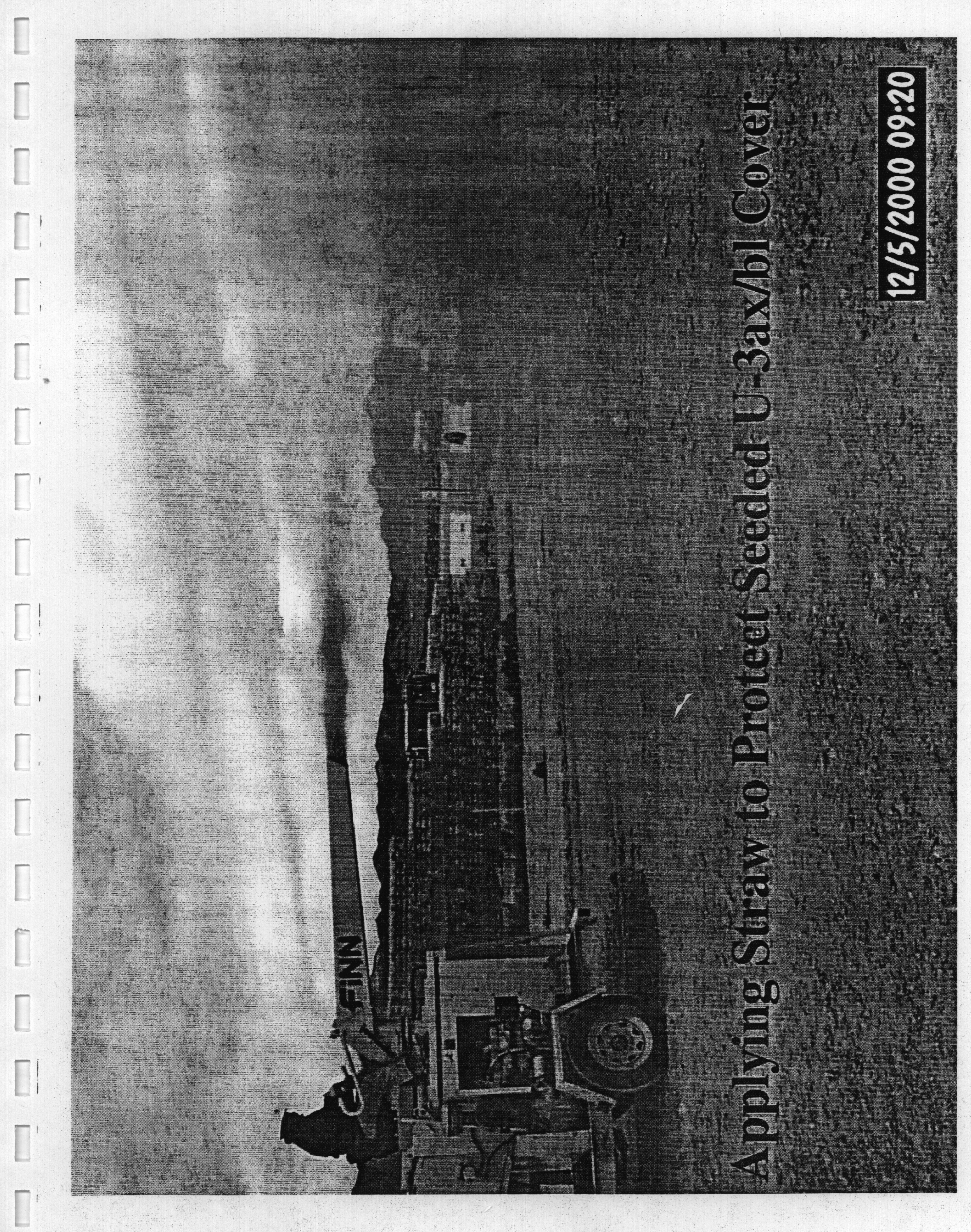


60 TITLE CAUilO Ax/bl Closive

PROJECT NO.

Work continued from Page N/A Meady $10 / 23 / \infty$

BOOKNO.

weathen: cold sos overcent istersmitent reins.

sotef $j$ : Tarigate brefing give on sith.

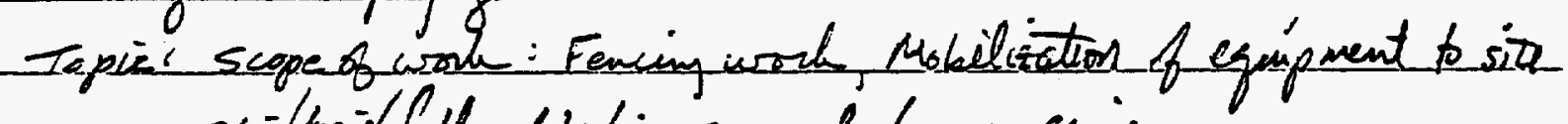

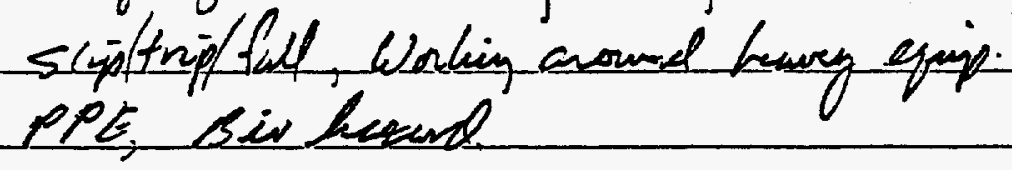

Feosonnel: Sit Supenison Chuch Womoch Tech Lend Kevis Complell HP Ciaighyous

Laboers Joe Jablonshi, Vistor Ramirez

ER tech Mike Floyd

Rad Tech mike Vanbillen, Tim Baker

Slectricions Jü Rainen, Gargu Gavdner, Rubin Cuaron

Operators Paul Robinsin, Danng Ellis

Safty Geni Cosk

Equeipment: BN/Ee Metro Van, bach hoe, Do for bomow pit va route

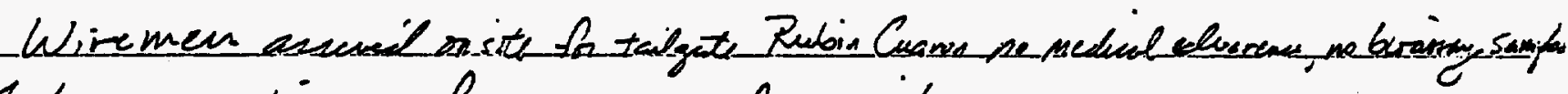

1000 Jaboers woshing on fence aceos al sesunify.

- Ons laborer viramirez aravid on site nithout and treining os heafth pecerds on fils. Good training smechul on Ramirez. All cument

Labores bave fening iget upe

Mouse metro van into position jint inside suppost ene

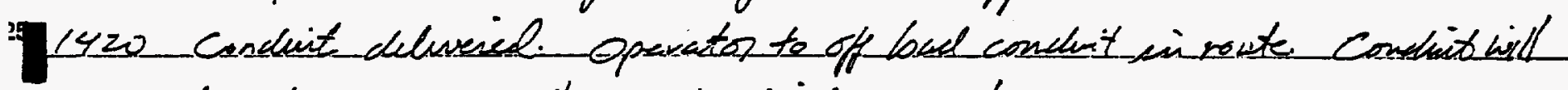
be placed near southern gate inriel suppoot zone.

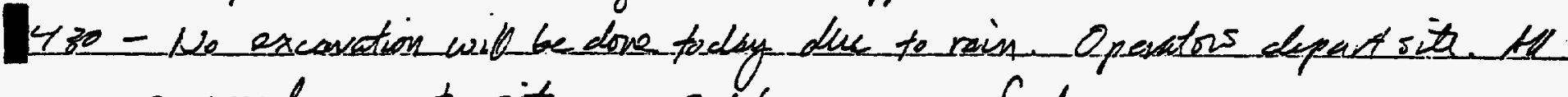
personnel except sith sup, 2 lebereve gone fn day.

Work continued to Page N/x

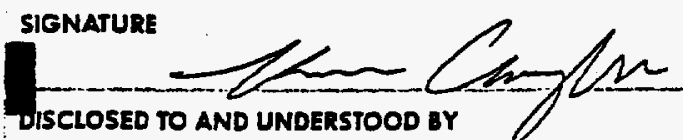

DATE

WITNESS DATE $10 / 25 / 00$ 
IIILE uqu rolbe ecosure

Work continued from Page N/A Twesday $10 / 24100$

61

weather: Orevent, slight showers, cobl bo's.

Salety: Tailgate gaien psion to stert of work Topie included:

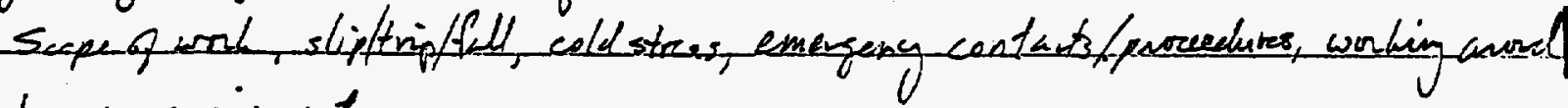
heary equipment

5

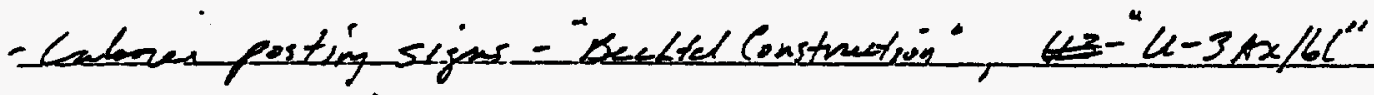
ond boction sappost zone

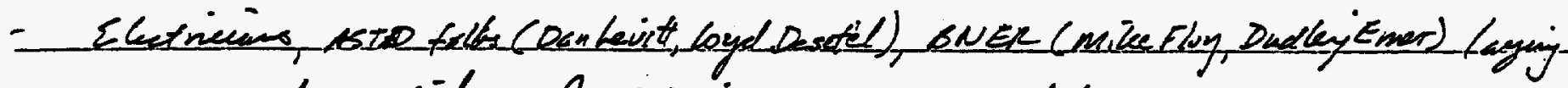
out cenduit and stringing Tor pabe cabeling.

- Medoc vansetup- hot ani sesteblished.

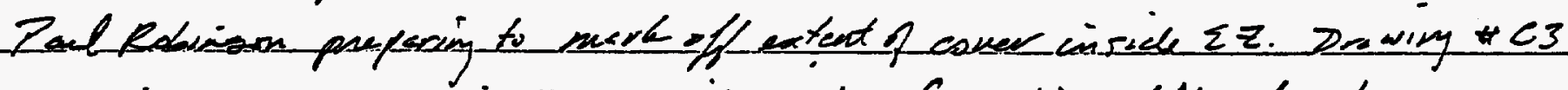

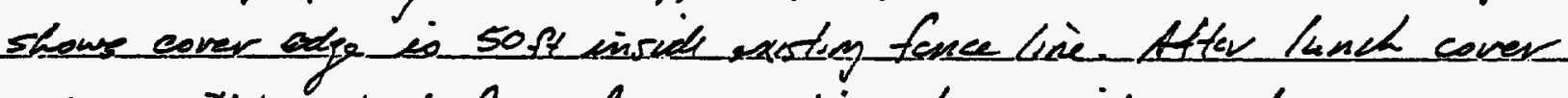
edye will be sterked a l eacanation of condint trench and ToR prote pits will bagin.

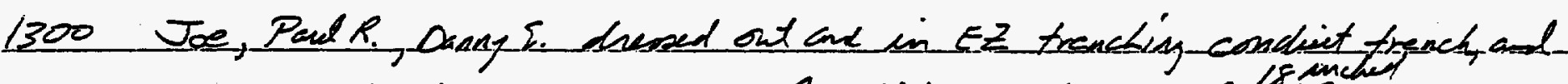

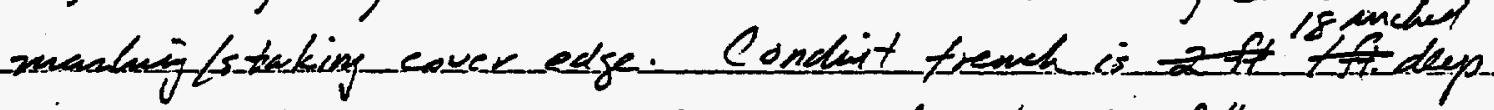

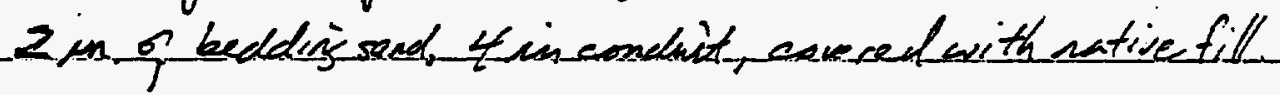

1 Blade anse cuest Acumbletion Traile wese delivered $\simeq 0900 \mathrm{am}$.

Completed excauting western most conduit trench and $=1 / 3$ of seemd wertent tench Asembled 2 conduits with cubel

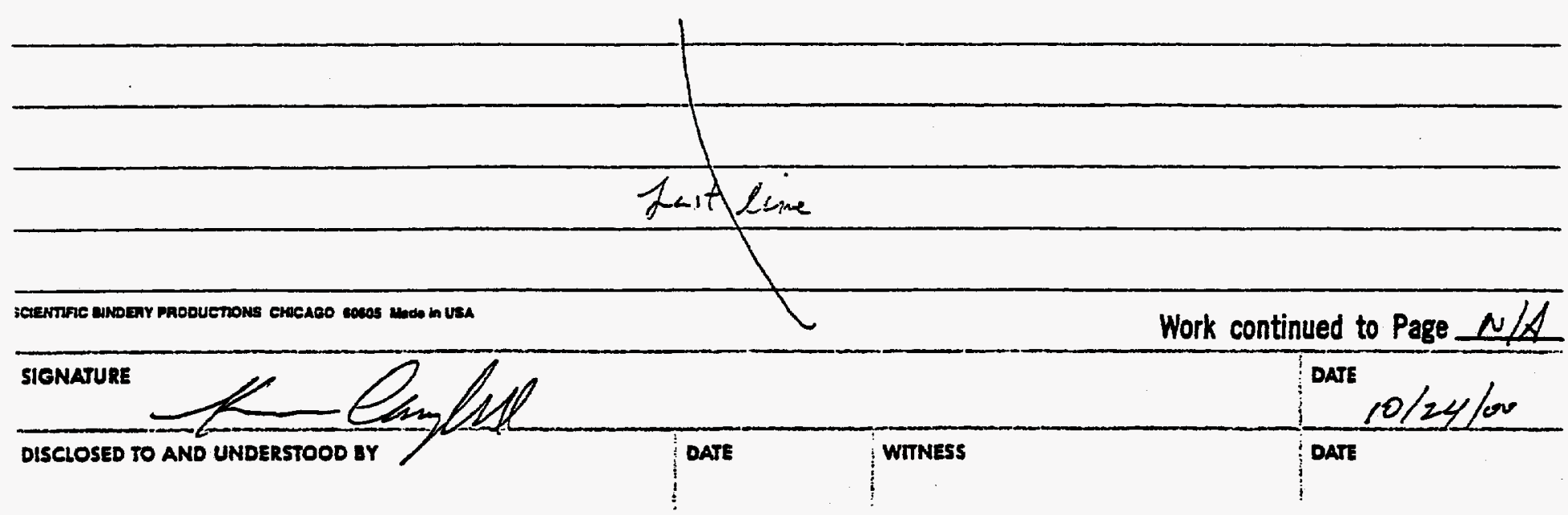


62 TITLE CAUI10 IU-3ax/be Closure PROJECT NO.

Work continued from Page $N / A$ Wednesdoy.

BOOK NO.

Weathen: Overcat sunshine coming though

Sefety: Weather indinient weather. hazado, Level D PPE in support zone, level C

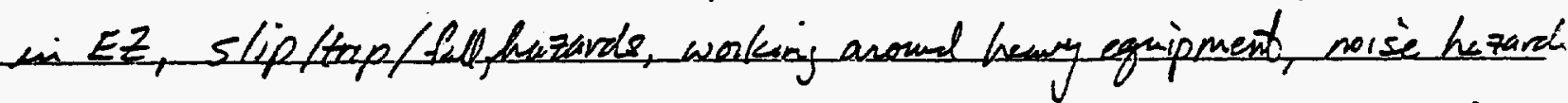

tetivities

-PRobinson continuing to stalis cover bounders

- Contivesing to excurit TOR trenches

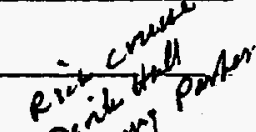

- Celiveded

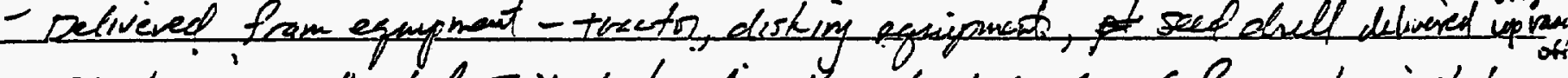

- Electracians atiended Taijgate breefing the bach to trea 6 for wook in shop

- Labovers polinging anea.

Visitios

Peronel

Hert Bensinger

Bo Rommel

Tohn Davey

- 10 yard of sand delwerid to site.

1500 wher truck deherid to site slight leak went to see mechane wonkin on form equipient.

- Permeter of cover staked oud Gade stales being plued on cover

- 3 TDR condnit trenches complete. 4th trench $50 \mathrm{ft}$ left to diy.

20 - AII 4 probe condint systems bare been weathenzed ung electiald tape\& weathenizing nubber tapes.

1600 woshers screened out of CA.

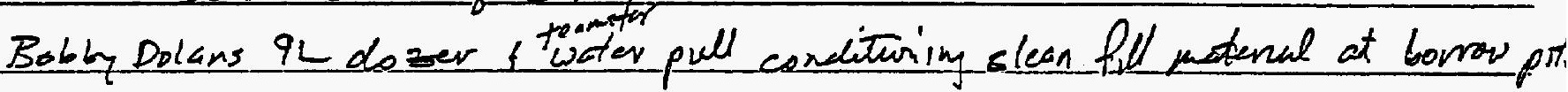
WateringASTD aren.

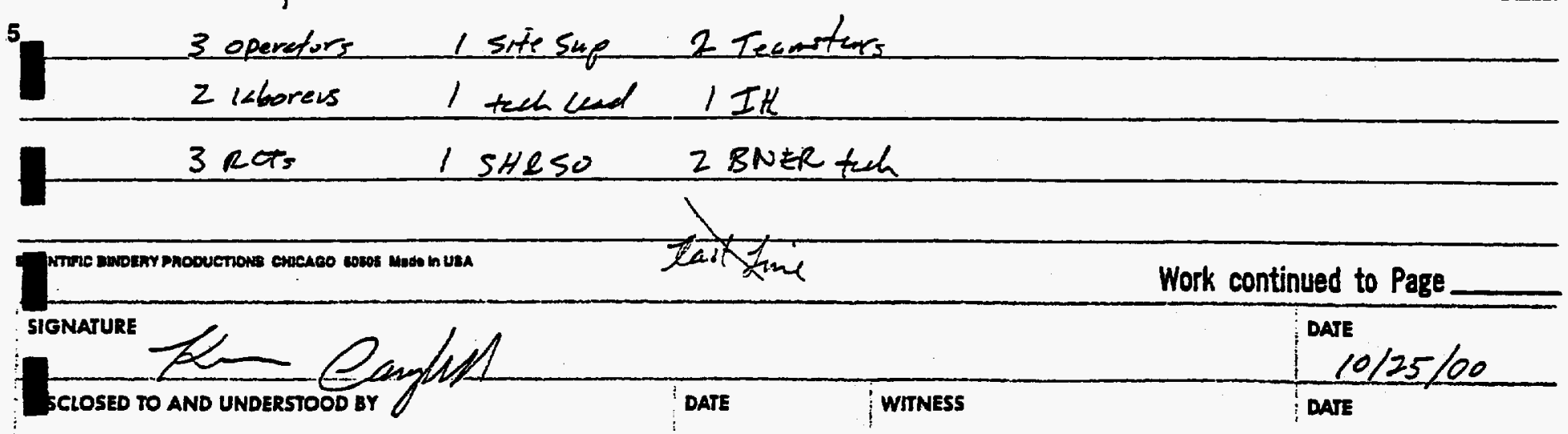


IIILE CAUIIO u-s ax/bl Closure

Work continued from Page N/A. Thuaselay $10 / 26100$

PROJECT NO.

BOOK NO.

wewther: Cool 60', overcest with partid sun, rain showers preducted

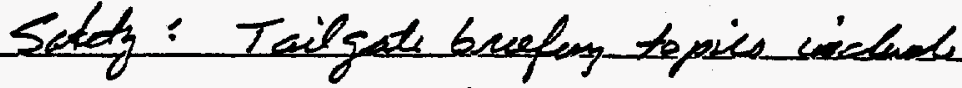

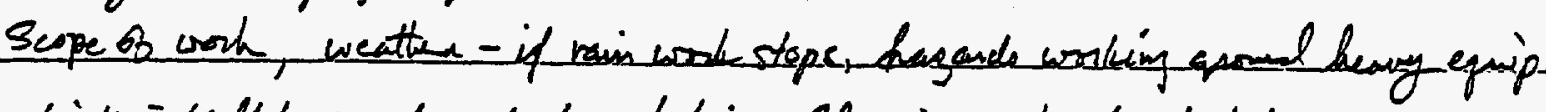

5 Vustors:

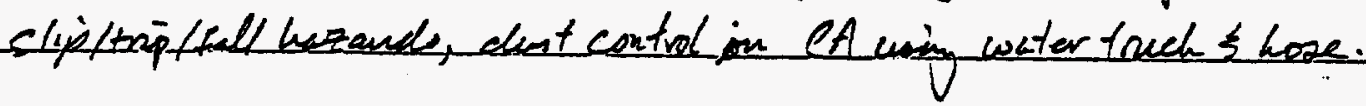

Rich Smith-125L cameranian

John Kit-perfniming construction audet

- Cintinuming to place gacde stake on cover

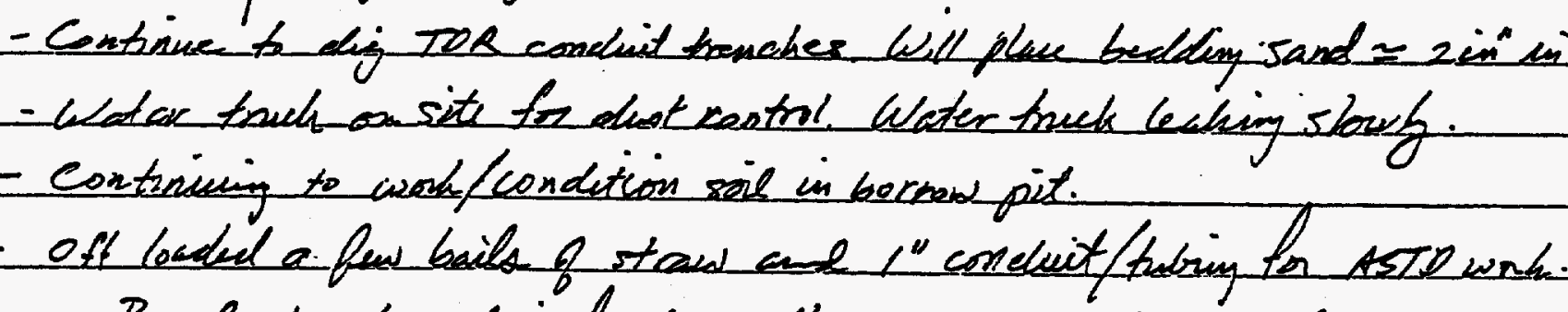

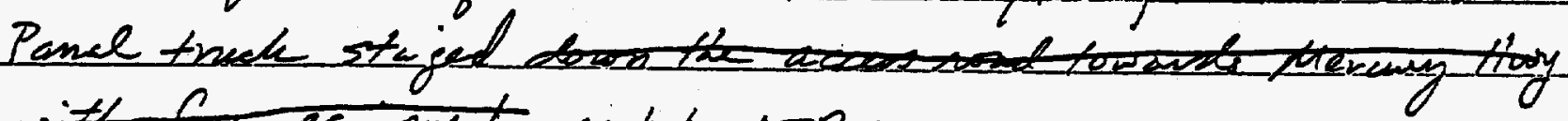
ate fan equepment. next to STR area

2 - teanstars (scnel, fuel) Bob Rommil
Deonis Finney

Ondered another $10 \mathrm{yph}^{3}$ of saude for trenches.

1330 sand delivered and demped

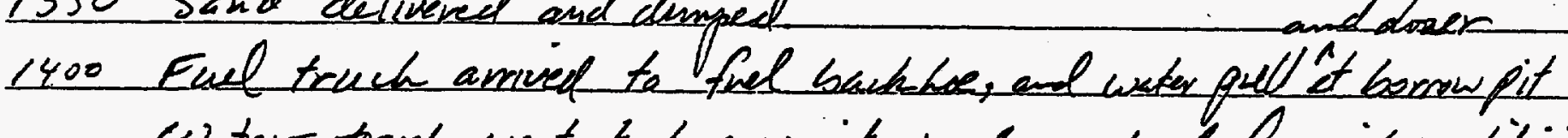
Water pruck went to borow pit to dump loed th sail conditiving

1430 still plasing sand in Ten conchit trenches

4 Delivered sso Front End Loder.

300 Oppart sity fn thea 23

\section{Int line}

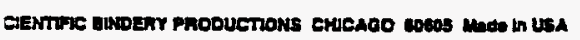

SIGNATURE

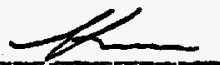

DISCLOSED TO AND UNDERSTOOD BY
Work continued to Page N/A

DATE

$10 / 26 / 00$

DATE 
64 TITLE U-3Ax/bl Closere Aetivitic

PROJECT NO.

Work continued from Page NlA. Monily $10 / 30100$

BOOKNO.

weather: Ram intermitant showes, cool 60's

Satety! Tailgate brifing grier an site.

Seppequanky cold strese,

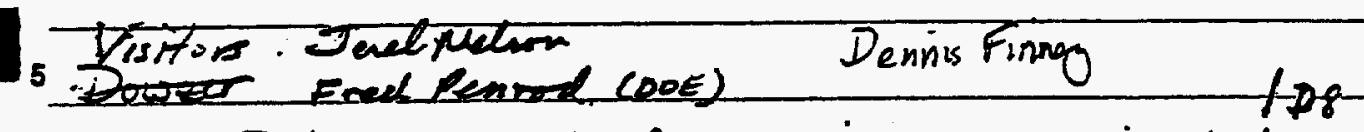

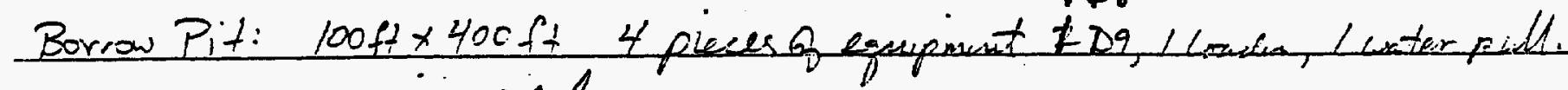
Fopering ailfor cover.

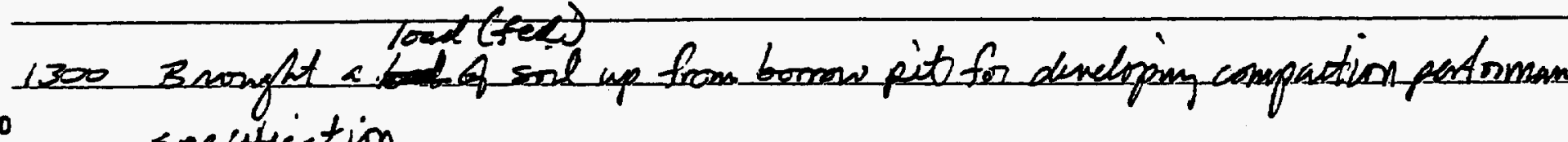
specification

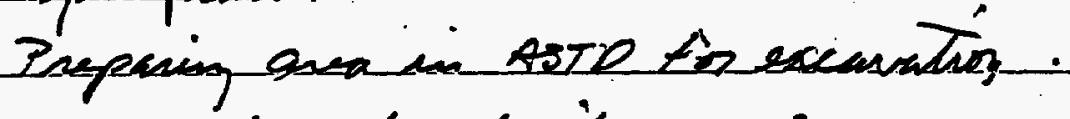

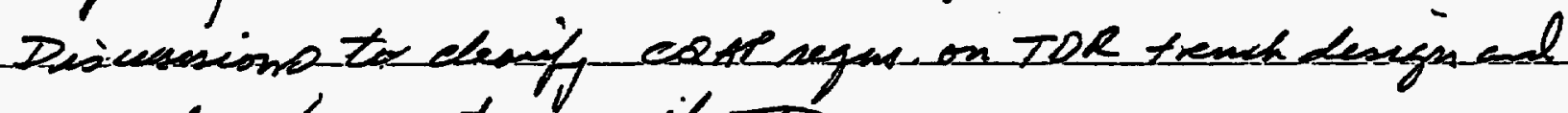
pade plenernent speceifecations

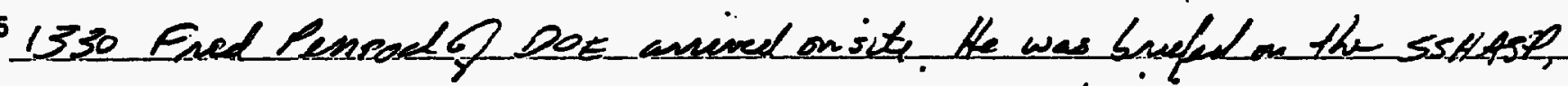
techechage to the SSHASP and Taigete buifung

1340 J.Large crived on sits with ivater tenber thedest supression dimsing excunaterst.

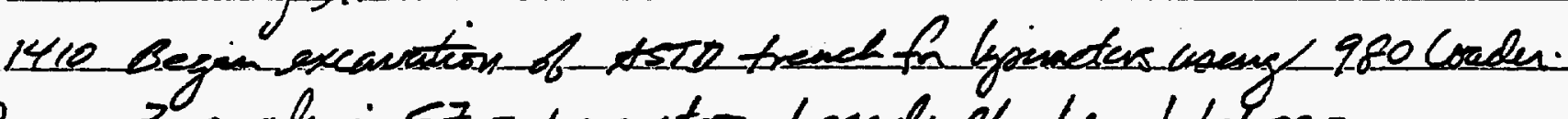

- 3 peghe in EZ - logeraton, I grade cheher, I laboner

Equpinuat:

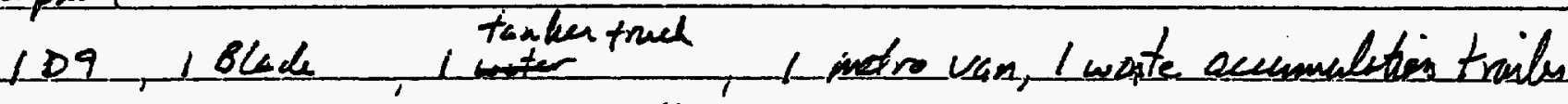
108,1980 cond, , wetor pull

Penconnel

3 RCT Ltechlead 2 laborer

1 solisp III I teamster

1548503 operatour

SIENATURE

Work continued to Page NTA

DISELOSED TO AND UNDERSTOOD BY

s. Cogla

DATE

WITNESS

DATE

$10 / 30 / 00$ 
TITLE U3AX/6e Closure work.

Work continued from Page N/A Tuesday $10 / 31 / 00$

Weather: Clear, high clomels,_cold!

softy: scope work, cold stress, slip ting fall

STA COYTOCON AuTO.

5

- Phone conversation ox Julie Sorola regarding $D C N$ to Drawing $C 3$ and Page $02222-3$ section 3.03 D.2.C. deming ion to $3 \times 6 \times 3$ deep. Julie. will fox con

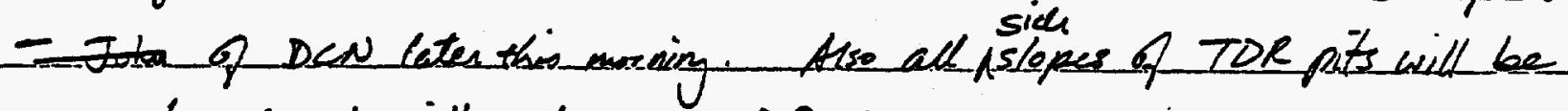
sloped 2:1 with a bench at 5 ff elem.

Discussions_of $P$ Robinson want medefuedtion to tor pit denis

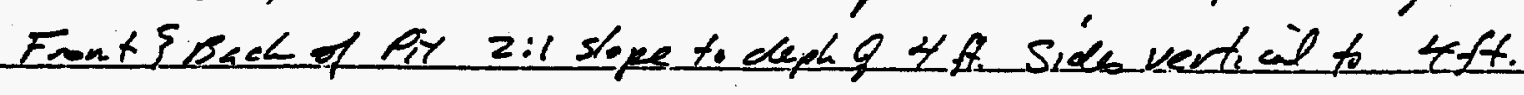
Beach of 4 ft dep. Bench is fy wide. 3 f deeper in trench.
PROJECT NO.

BOOK NO.
65 
66 TITLE U-3axlbe Closure Activitues

Work continued from Page 65

PROJECT NO.

BOOK NO.

Asto Personnel

2 epentore

2 bboen

1 terster

RCT

1 AP

cxullo Pessennel

2 dedricum until 1200

2 BNER tech

1 Pan Luitt

1 Operatos

1 Labor

1 nase

$2 R \sigma$

0

After noon

Als on canve

Copy-of email frem $\triangle$ maduen to Sorolla received acyanding DCN for compacting test pael ad dexing of Tor pits

co0.444-21

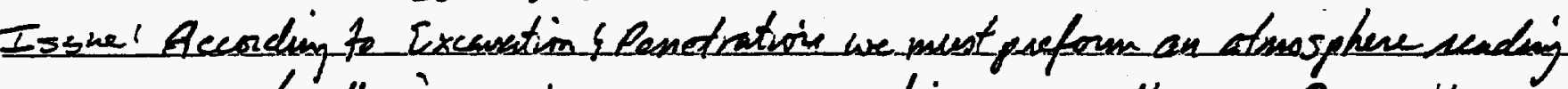

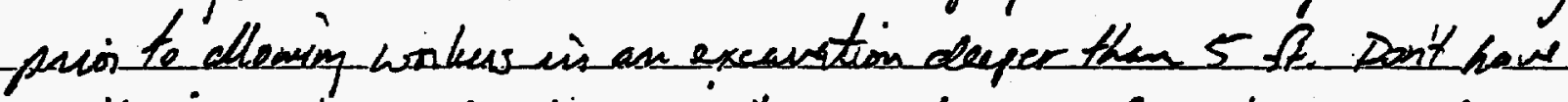
maitoring equip on hand I Vincell went to CP-SO for multiguss meter and froin

Visioirs: Temmy Come Plaving tor pirbes is on holl.

Dennis Fininey

Jetf smith

Katly Tharin

i2:30 Beause of dust being produced is asto eacesiation ad se disection of winle 1 eleculed to Lalf sto work to

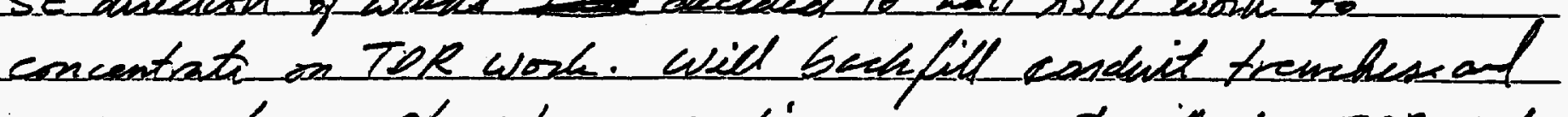

once we have a otmosphere seres probes SIGNATURE

DISCLOSED TO AND UNDERSTOOD BY

DATE

Work continued to Page

WITNESS

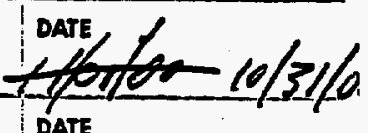


TITLE U-sax/be closure trarvilum

PROJECT NO.

67

Work continued from Page 206 Tues day $10 / 31 / 00$

BOOK NO.

- Spoke with Vic Dunn \& John Dover about case of making an

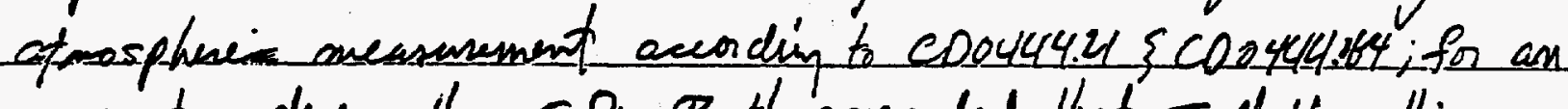
excavation defer than 5 ft. Both conceded that Jeff Vincalli is qualified to male there meannements. Fo each TOL probe pit an $O_{2}$, LEL, toxiaty measurement will be made pin to allowing

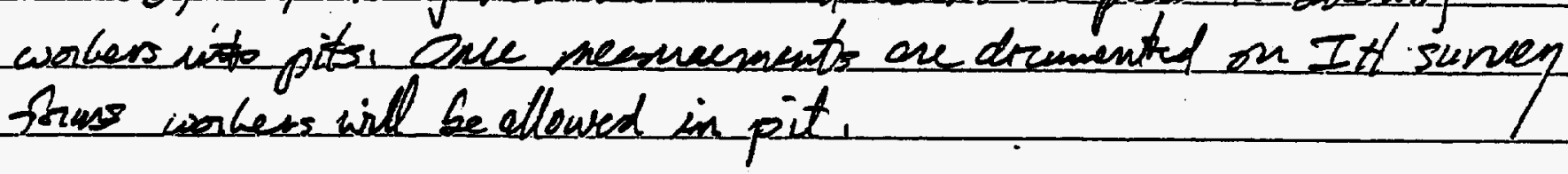

- Batffilling with soil and sand Tor con dint trenches.

$1 / 400$ Jeff Vincallic returned from CP with imutiges meter '30 Second water tenter, front end loader ( 580 ) deliver al

- Trench s will be inspected by certified Competent Person daily. A supped Trench Daily Inspection Report will be isi-project file.

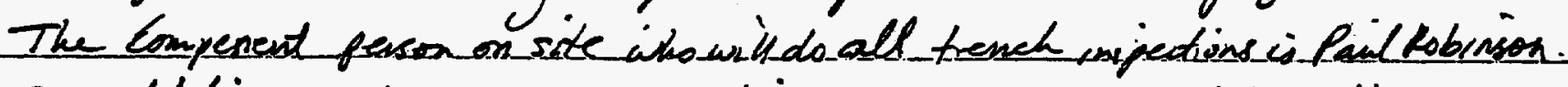

- In addition, whenever excesentions ane open and diver than $5 \mathrm{ft}$ an industrial lysine surveillance will be made of the trench at mashes $a_{2}$ LEs, toxicity will be determined. Jeff Vincolti will make

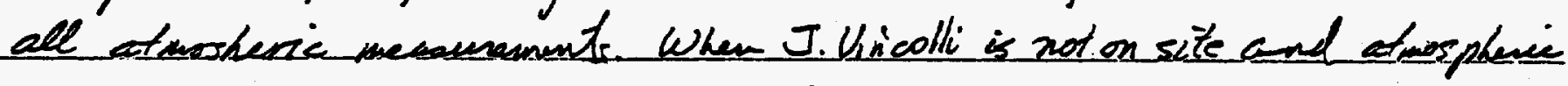

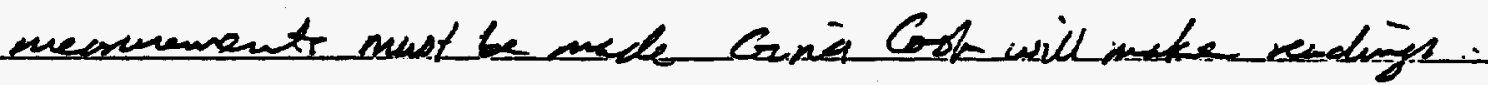

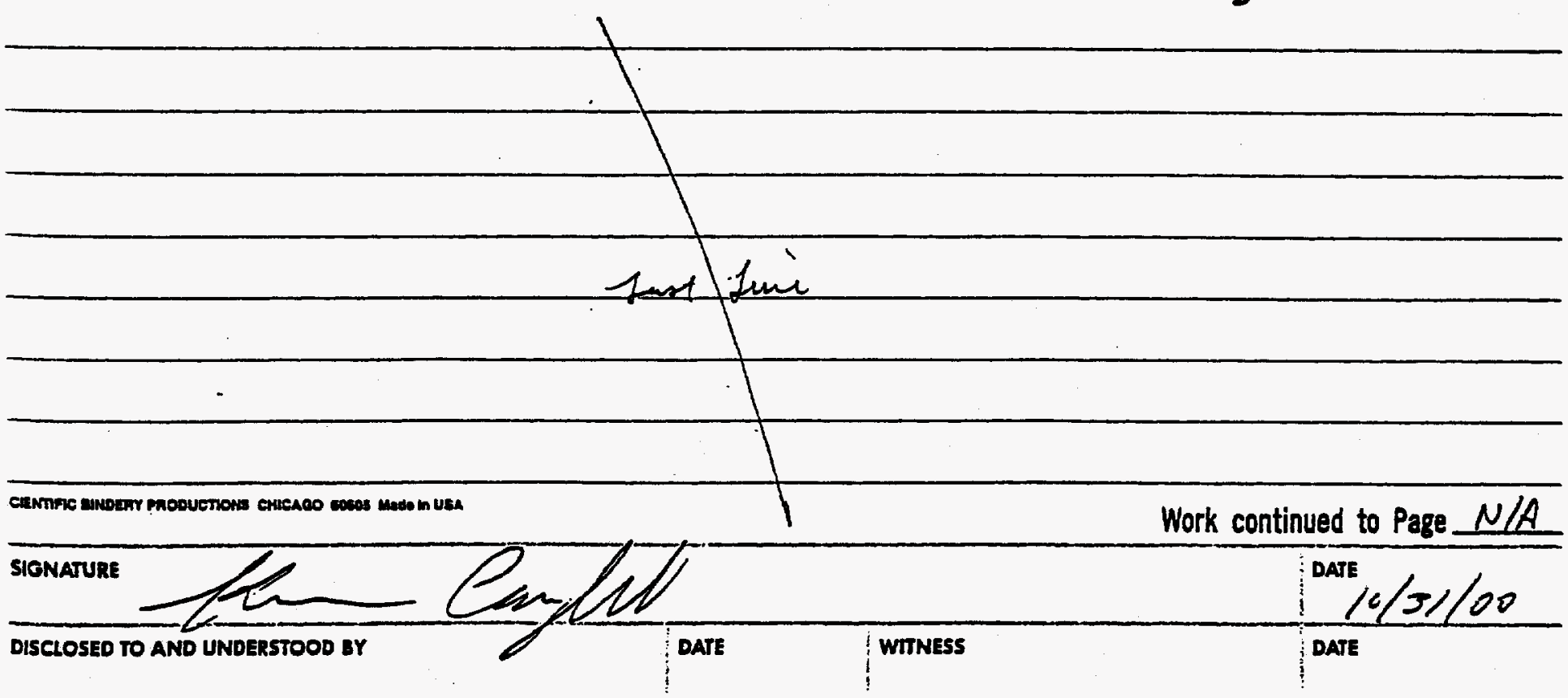


68 TITLE U-3ax/be elozure Activities PROJECT NO.

Work continued from Page wls wednesday $11 / 1 / 00$ BOOK NO.

weather Clen, col low co's colm. Predited winite for afternow,

Safety: Scope of worh-Plase ToR probes, Rad Survey, brechfill conduit nurs, Beginhilinf-pluing clem fill on explbe coven.

5 Vistors: Pat Thomer, Warne- Hedges - Fuelers

Bob Rommel, Stave Nacht, Paul Brow

Dave Mudsean, Wagne Jihnson, Tered Nelsen, Dennis Gustatson Jach Mahan

0745 Tailgata given. Work will be on Axflel tuday ns Asto wook.

criw:

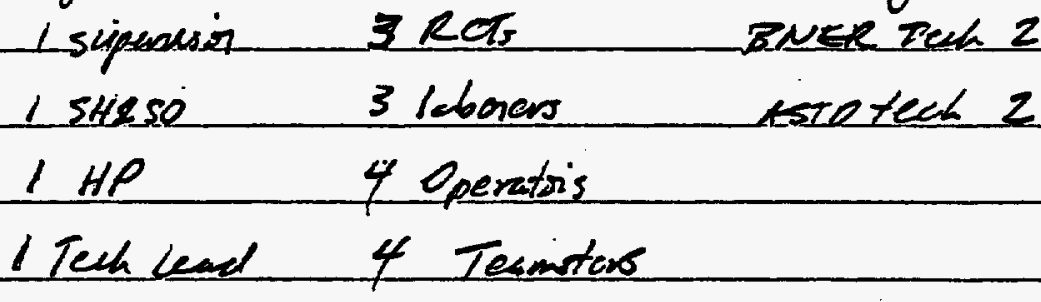

0830 Crew dreming ont to plew TOR probes.

0900 Fut Finst condeog dit fren barow pit delwered to cover. Clem fill

being plued at fence bine ad bing puched onte coves using Do dozer

os30 Euders ansins to refull equpminto

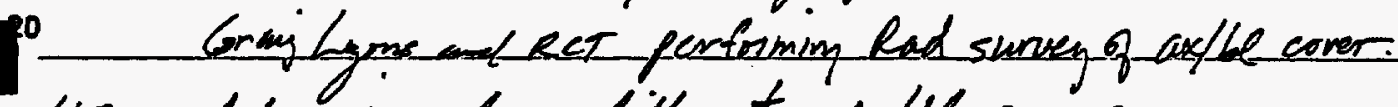

1100 Alvensing cluan fill onte Axlbe cover

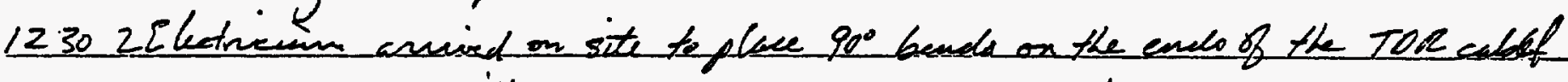
condenits. Hles will place metal tape doove condint is future undengroud erculin

1300 oner monemet_kisitios depat sit.

1300 Second Tailgate bueping gion to emphasize that wakere were not to mave onto or off of the cean fill being cadmencel into the $E Z$ (CA)

and viciverse.

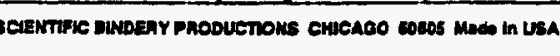

Work continued to Page 69

SIGNATURE

He Choph

DATE

DISCLOSED TO AND UNDERSTOOD BY

WINESS

ullelloo 


\section{TITLE}

Work continued from Page 68
PROJECT NO.

BOOK NO.

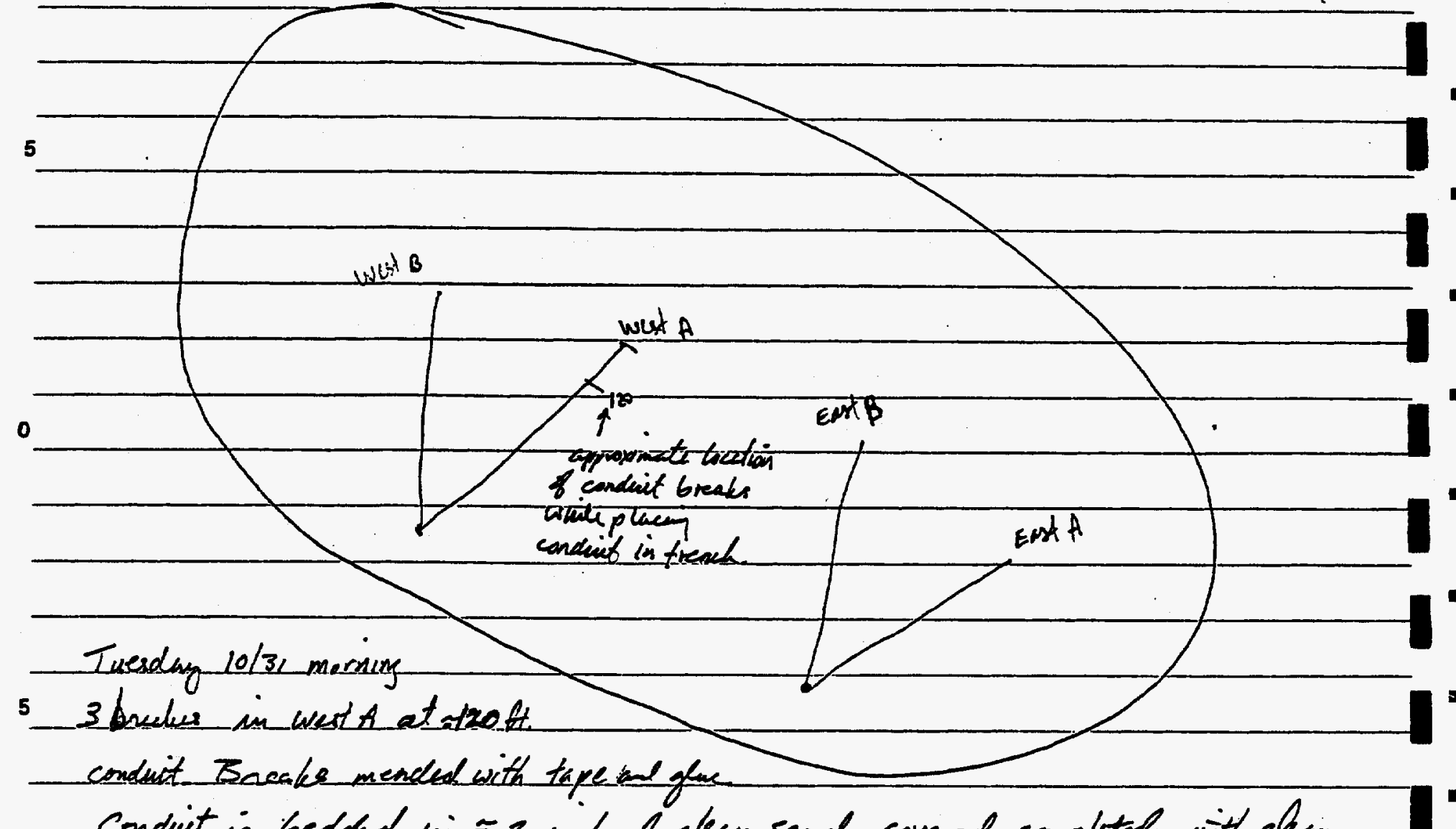

Condint is beded ni $=2$ meher \& clean sand, covered congltely with chim sed, and the cavered with excancted siil. Detection fape is plused in prench at apposximately IA bjs print caser.

0

1330 ondered 10 yd' of clean sand to complete bunial of East B and Eant $A$

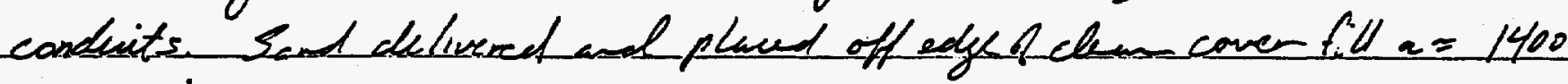

1440 Sxcavating the Wat B TOR probe pit.

continue to expand cover with dear flll

\$1450 Rich Smith amvid on ite to tabe vidio

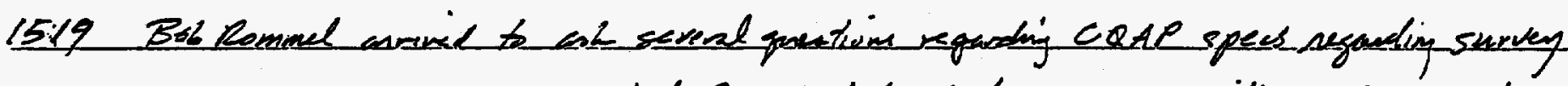

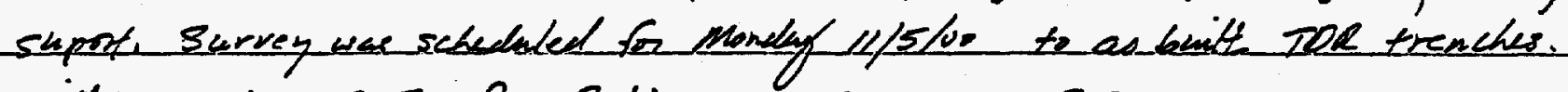
Will argusent a ROTC fo Sedion 01050 Partz $201 B 2$.

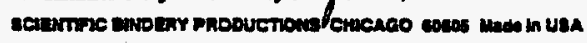

SIGNATURE

DISCLOSED TO AND UNDERSTOOD BY

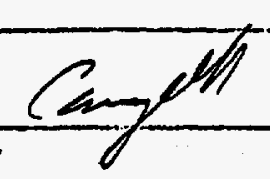

Work continued to Page 70

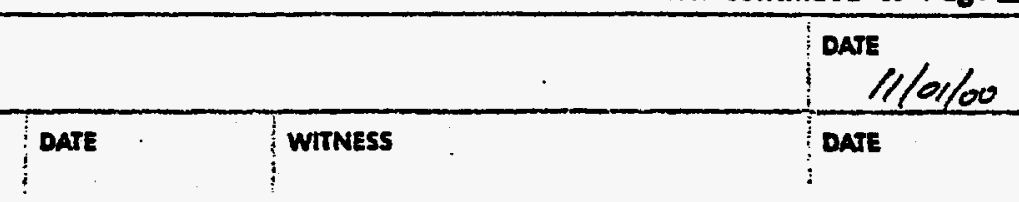


70

TITLE

Work continued from Page 69

PROJECT NO

BOOK NO.

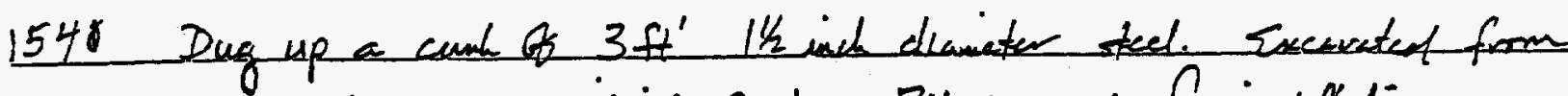
$5 V_{2}$ fact dep. Notified Craig Pit is ready on installation.

Unessered pipe white sloping the issuer edge of pit.

Pipe oil be surged in am.

- Covered about $100 \mathrm{f} \times 110$ ft of Axle with chan fill.

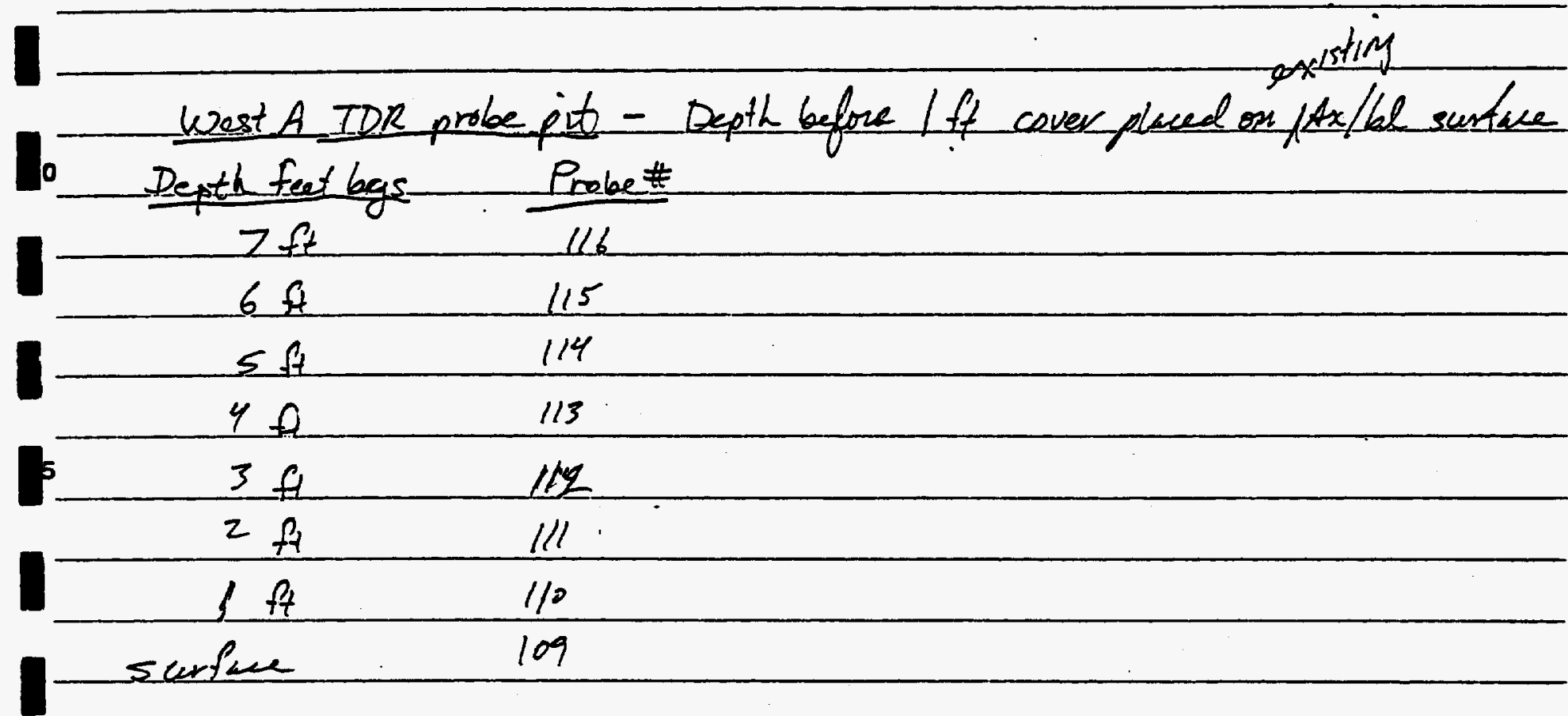

TDR probes installed by L Desotell, M Floyd, I Dixon, D Ewer Lest tim

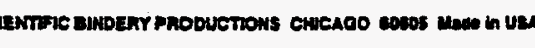

SIGNATURE
Work continued to Page NL S

DATE

DISCLOSED TO AND UNDERSTOOD BY

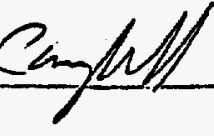

DATE

WINES

i nate 
Work continued from Page N/A Thurselay $I I / 2 / 00:$ BOOK NO.

71

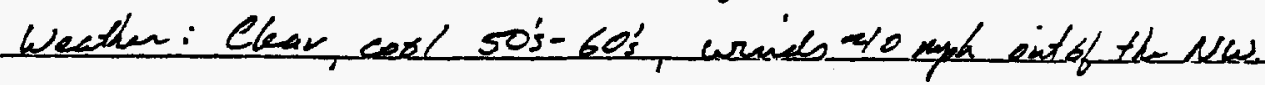

Safety: Taxtgete guin at job isth. Tepees

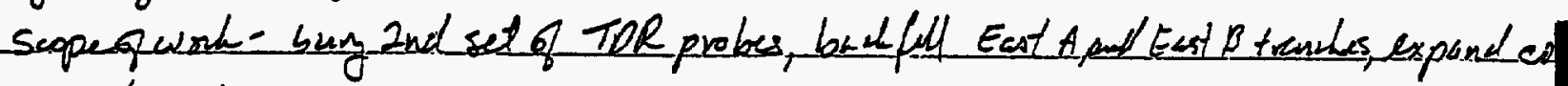
cold/wenthe

5 slip/tniptiall

Visitors! Fred Penrod Dot, 0830 Began hauling soil from borrow pit to cover

- SHSSO performed atmosheric monitoring in TOR probe trench West $B$.

- P Robinson did trench inspedion of wat B Tor probe pit

- RCT dressed out and did a rad survey of the puce of scrap reba 3/4" dug up yesterday while sloping the rear sick of the Wert B probe pit.

- Bacfilting Easting East B trenches with clear sand.

ito - Rich Smith on sit taking video skate

5

One tod samey clew tor wert B probe pit, M. Floyd, I Dixon will place the hint 2 expert probes by hand in wast $B$.

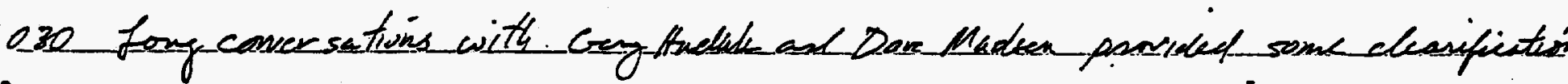

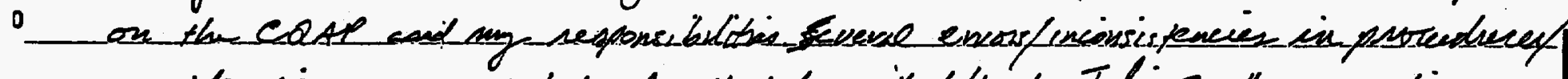

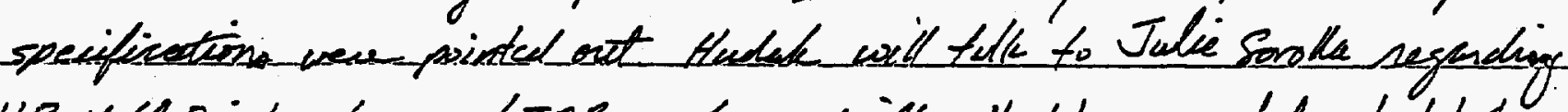

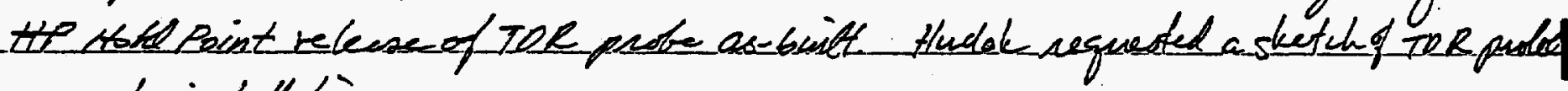
nest installation.

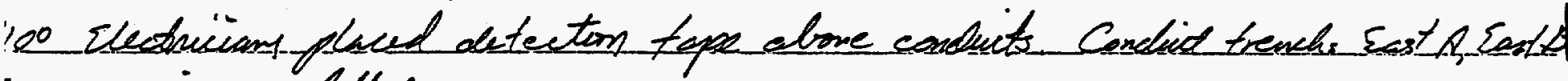
; being betefielled.

00 Mechanics annie to wash on replacing large louden nipping teeth -30 Final Ton produce burned in West 8 probe pit.

Continuing to expand

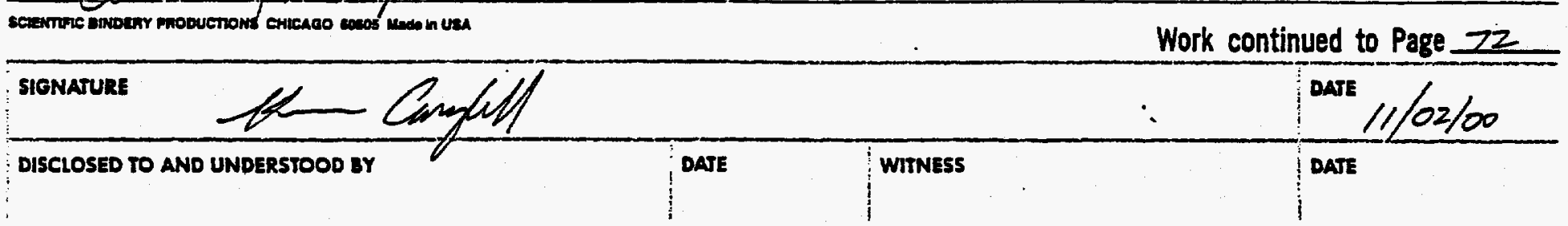


72 TITLE CAsi10 Closure Activitis

Work continued from Page 71 Thursdy $/ 1 / 2 / 00$
PROJECT NO.

BOOK NO.
1 site sup
1 SHSSO
1 HP
1 Tech lad
2 Eleutricuars:
5 operators ( 1 lett
3 baboes
3 RCSS
4 BNERTach
1 ASTO tech
1 video (half dey)

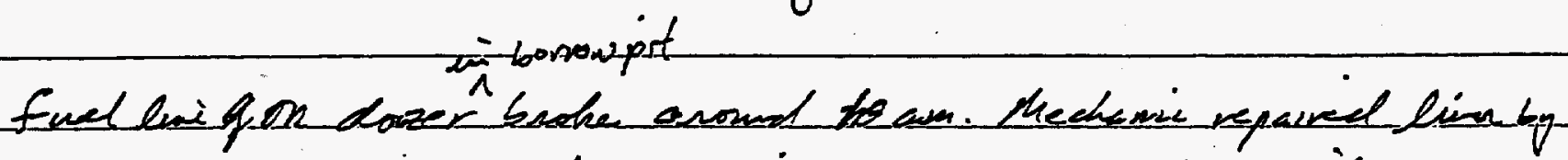

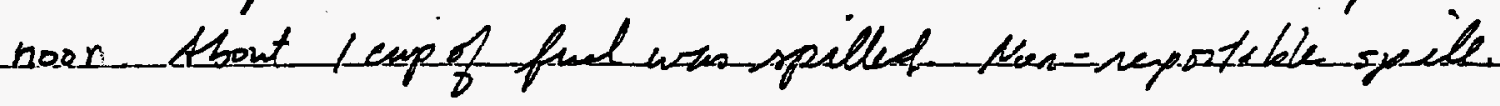

Rad sunvey of prici ? sebar showed nothing-dowe background,

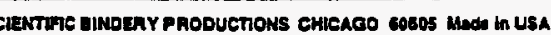

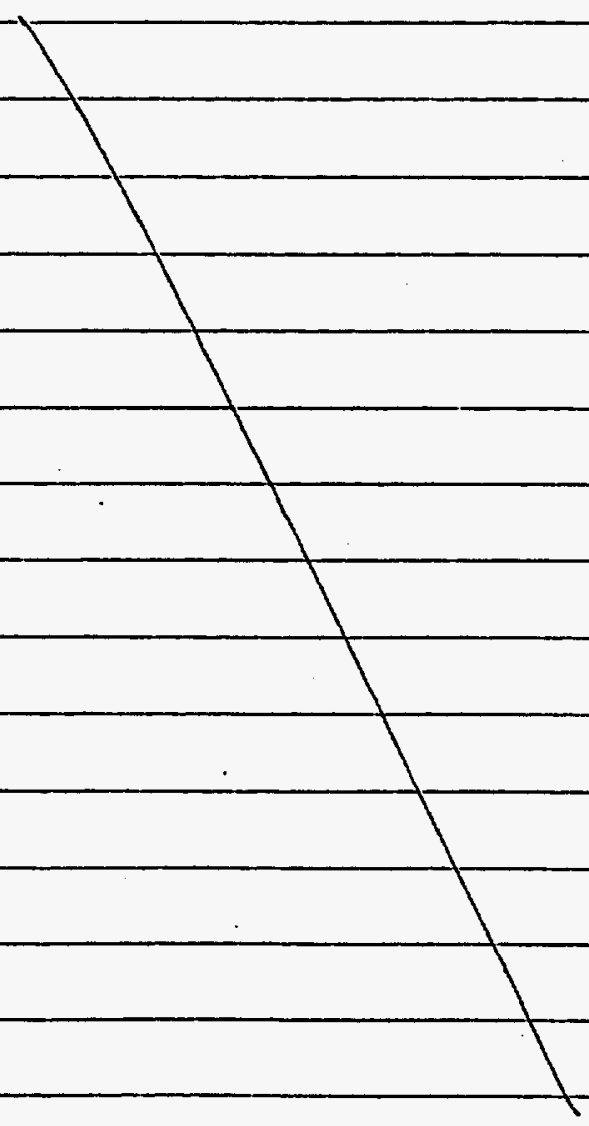

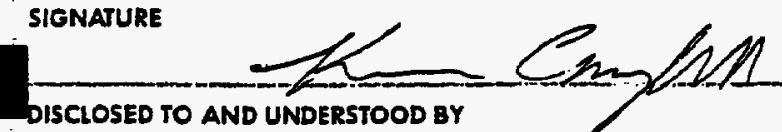

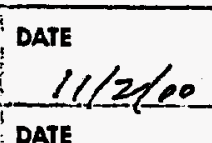


HILE CATIIO c rosure nt.....

Work continued from Page N/A moncly $11 / 6 / 00$
PKUJECI NU.

BOOK NO.

73

Wather: Clear, cool ligit windo frem the north. Wuids ans supposed to

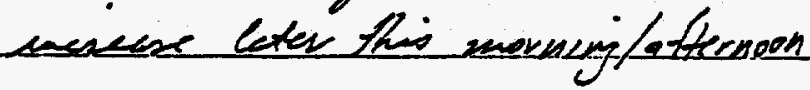

Safety: Tartgate buifingnix prion to start of work.

5

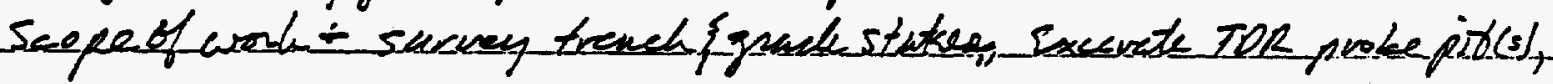
plen DaR probs, contimes cuoble on caver.

- Sunveyos (2 of then) shawed up and were breffed. Both ue on bionsang and so wosk dosent seed to stop whil one of then

0930 Mechanis (K. Parber) campleted fitting 988 loader with new catting teeth.

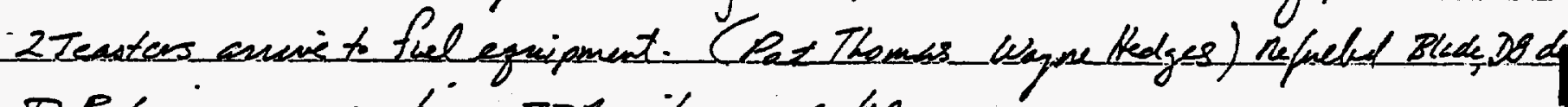
PRobusion exceuating IoR pits on Ax/bl.

O946 Wetering Aste sod pile to costrol dust Winds mereanges kichiong cep-dust

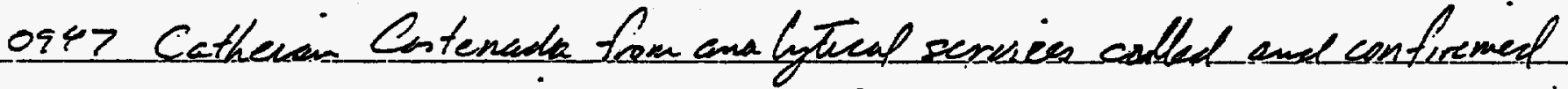
0

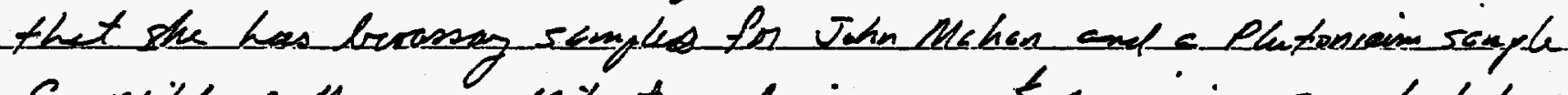

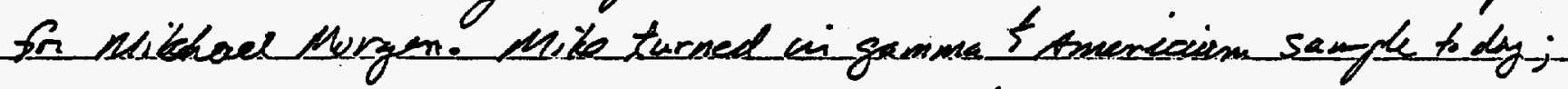

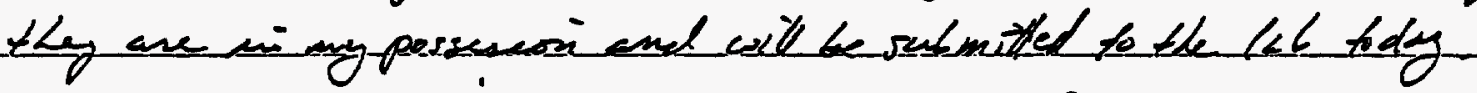
10.30 Completed excevating Eeor 5 TOR pit Working on Eant of A pit

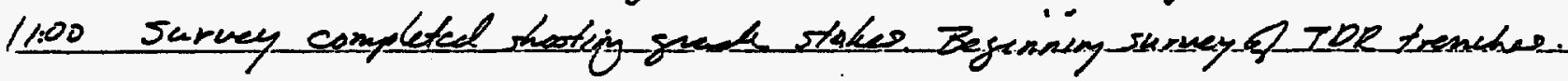
5

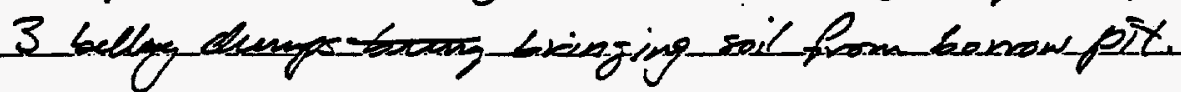

1:00 Both Eaxt $A$ ad Eat $B$ zor probes excurated.

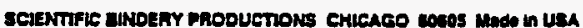

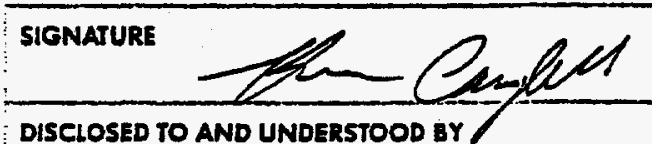

Work continued to Page

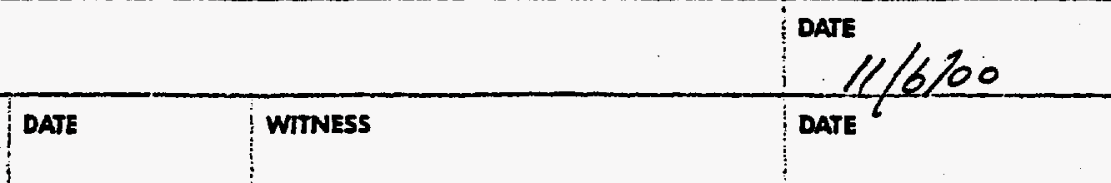


74 TITLE CA1/0 Closure Actiritus

Work continued from Page 73 Monday $11 / 6 / 00$
PROJECT NO.

BOOK NO.

12:30 SHESO in CA(EZ) performing atmospheric monitoring of TOR paste pits Atmospheric monitoring showed normal ambient conditions

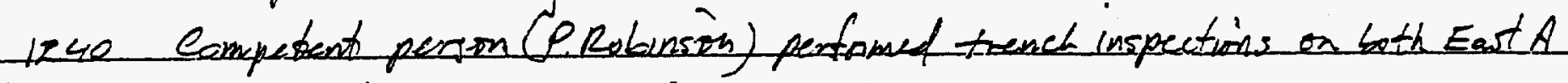
and East o Tor probe pits.

5

1300 Excavation' of East s pit uncovered a smell puce of flat stock metal

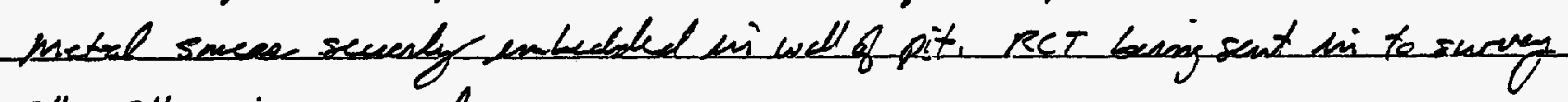
$3^{\prime \prime} \times 8^{\prime \prime}$ pice exposed.

01330 Ton pit of East o is to fur ont numb, excavation WII be bach filled is ed french end expandedfexslaged to accomedate probes.

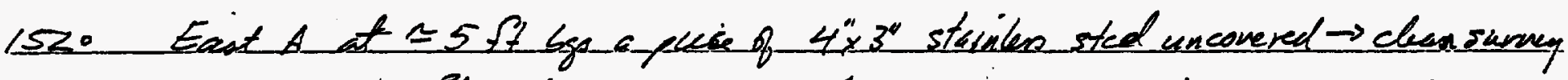

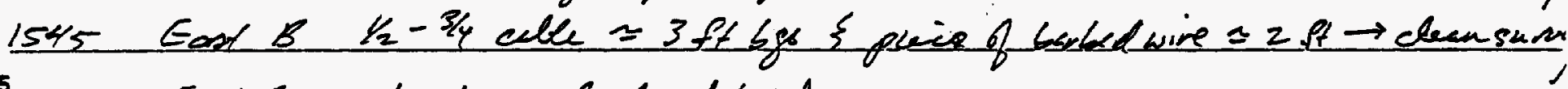
5 East 15 one breeds $\rightarrow$ glued ad taped. cist $A$ two bush $\rightarrow$ glued ad taped.

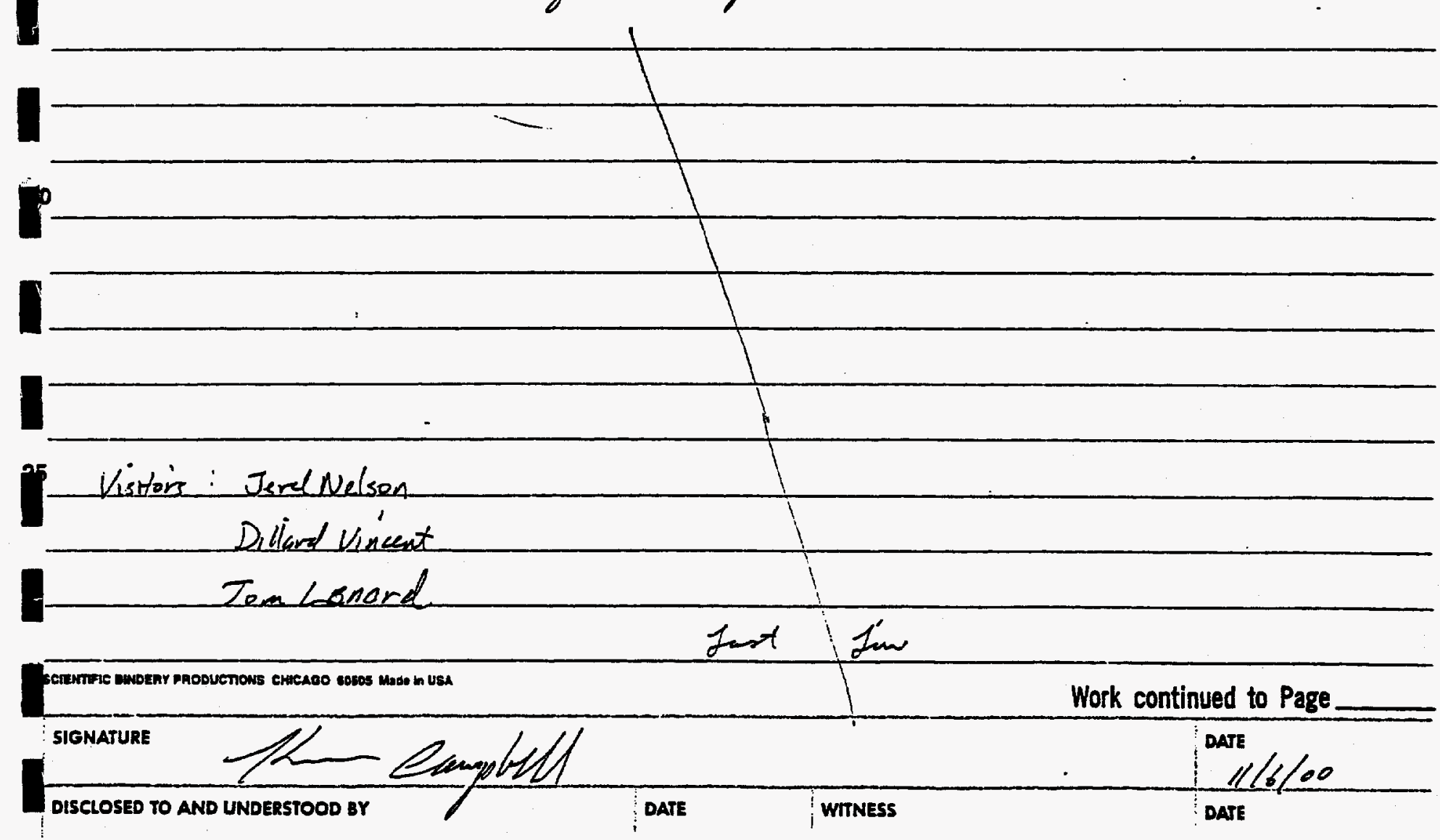


TITLE CAuls closure Activities

Work continued from Page N/A Taseday $11 / 7 / 00$

whether: Clear cold so's very windy

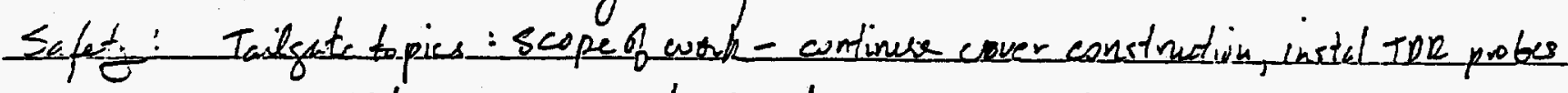
edd'stay warn, take heals when needed supitrip, fall hazard.
PROJECT NO.

BOOK NO.

75

5

Visitors: Jeff smith

Gary the dele

Tot Jurel Nelson

Sabine Curtis $200 E$
Teal to s - NOEP (10am-11a.m)

Rich smith - RSLfuidere

10

0800 Moving loads g soil panto cover

Walking on ToR prob placement in East $B$ pit.

5 loss Completed installing TOR packs in East B.

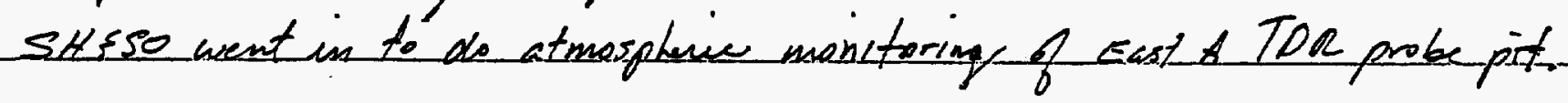

Conversation with I smith \& G tweak regarding CQAPChedulist. Will make notes on when CPL HP an released and how the release wee madefdrcumented.

$\mathbf{0}$

Have 3 belly damper remaining $2 \approx 20-22 \mathrm{yd}^{3} / \mathrm{locd}+1=17 y \mathrm{~d}^{3}$

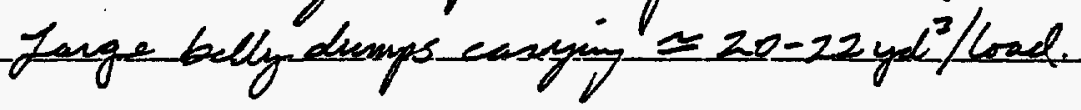

1'10 Doespresentetives depart Sit.

ill:30 Jeff Smith departs it te.

1400 Completed instilling TOR Parker in East A TOR probe pit!'

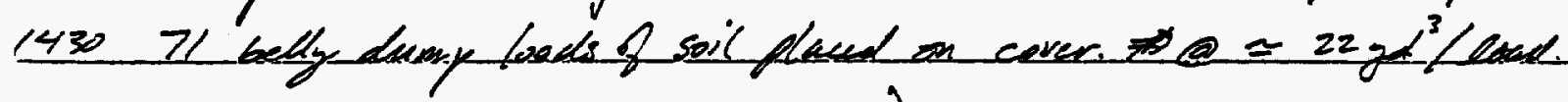

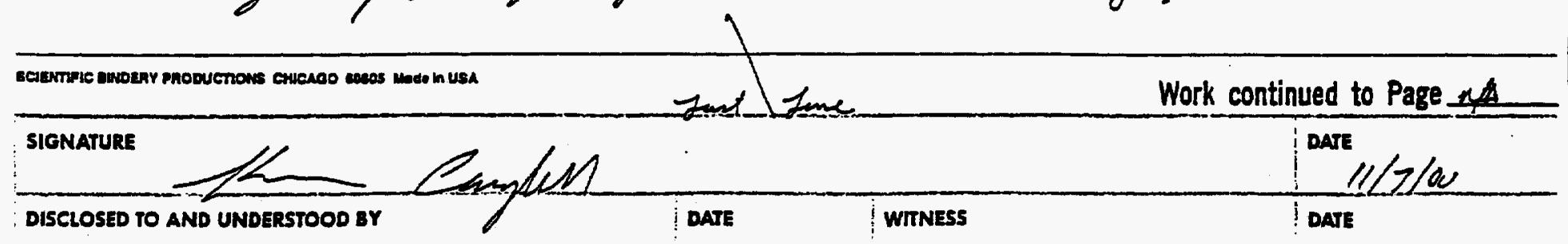


76 TITLE CAUl10 Closure Activities

Work continued from Page N/A Wedneselay $11 / 8100$
PROJECT NO.

BOOK NO.

Weather: Clear, cool 60's, calsu souninds at 0900

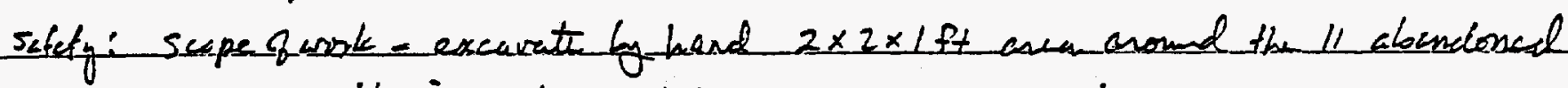
pue monitoring welts, continiu cover exconstruction,

- seip tojifell hazards

- Hasends for of waking avound heory equipmest

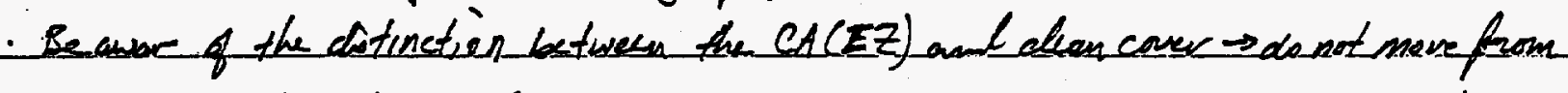
one te the other whil on conerasca.

- cold stress hazands

- High wind hazards

O830 Continuing to construct axtbe eover.

0830 Hand excavating on asea $2 \times 2 \times 1$ fis anend the aboudoned pre monitionin

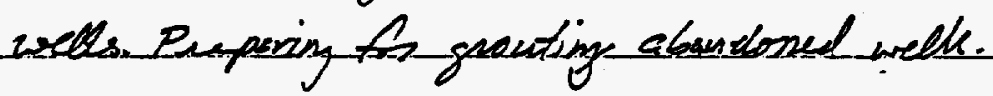

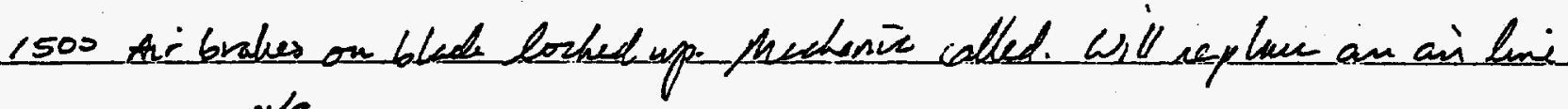
on rils am.

110 belfy londs pland on cover $e \simeq 22 \mathrm{yd}^{3}$ each.

is Appeximathy $45 \%$ of cover coinflet

PVC pypes cut off at $=$ C"below ground surtar. We ane saly to gront doustoned wells

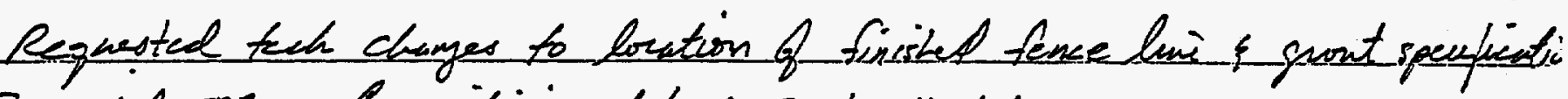

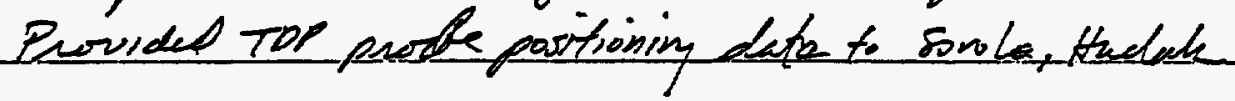

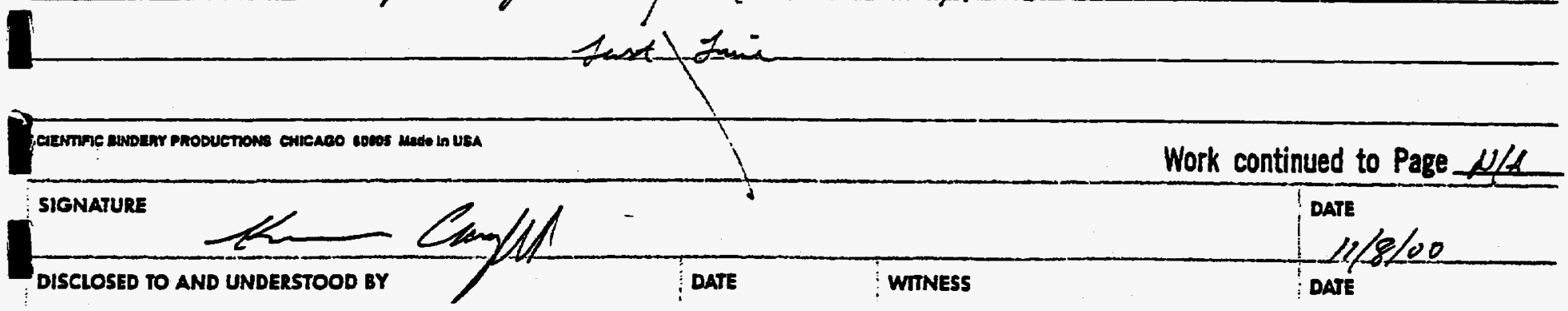


TITLE CAUl 10 Closure Aatinitus

PROJECT NO.

Work continued from Page N/A Thursilny IIIfloo

77

Weather: Overcast, ede Sob, culm. After noon: hight snow showers.

Sift! Continue cover construction

Itaseards working around hewer equipment, wear orange vests

visitors: 2-fueless

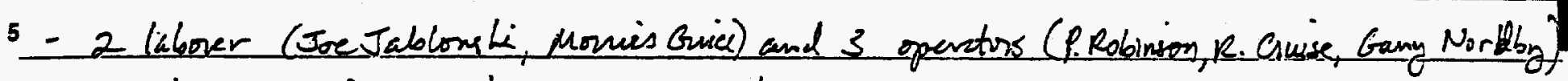
attending defensive driving course until 1200.

Mechanic onsite workizon air line on blade.

- Moving dist fro kern pit tu cover. Hazer placing did.

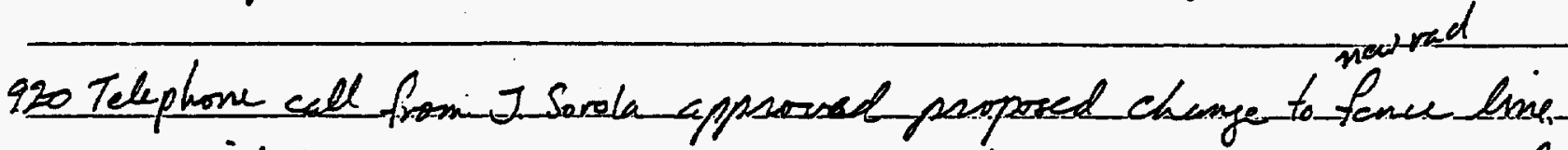
She will inside a DCN. We base appossal to construct the new rad fence with is 5 ff of the existing fence.

5

13002 laborers 53 operators returned from touring.

1310 Concrete vault and associated concrete ports for ASTD arrived on site 4 pipe fitter asir fo offload vault.

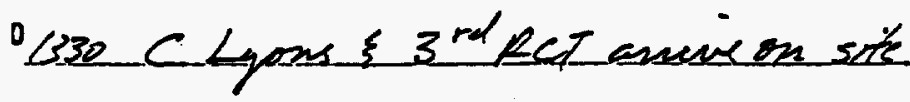

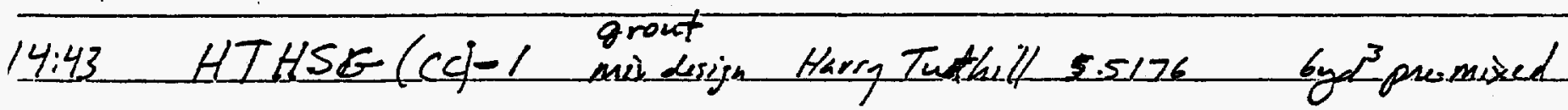

sol- Snow fulling had now. still no cecumaletion

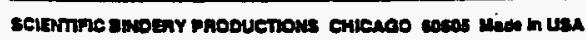

SIGNATURE

DISCLOSED TO AND UNDERSTOOD BY
Work continued to Page N/S

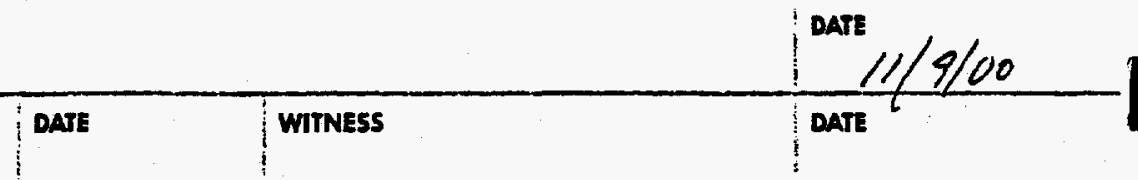


78 TITLE CAUl10 Closure Arativition

Work continued from Page N/A Tues day $11 / 14 / 00$
PROJECT NO.

BOOK NO.

weeather: Clear, cool 50;, celm

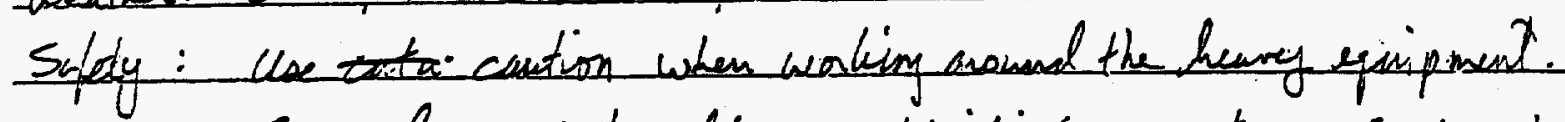

San glave in the ofternoon blinding operators so teurster need to exercise eaction when wolling on covec in alternon.

Visitor: G. Hudak, $R$ sunith, stureasinson

continieing to consinect Alble cover

Ontinien to excente Aste

- Tremi cont abondoned wells

- monument ondercedf cast

Asto enew

2 opesators -

2 ichresa

1 teunstex

2 ReTs $\simeq 7$ hereh

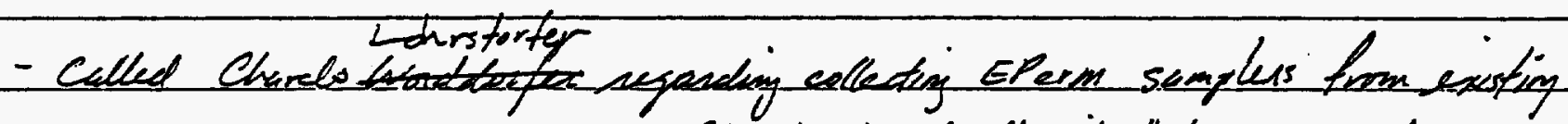

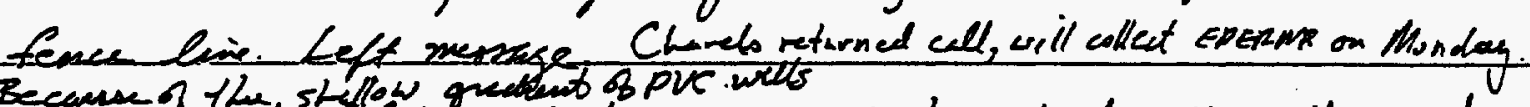

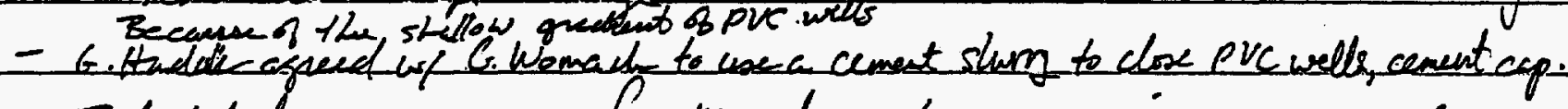

- Schedulid survey caw fo terondary IItze. They will tope conef lozate pre wells, worken Asto traned.

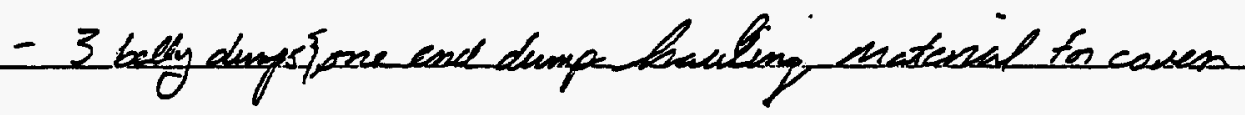

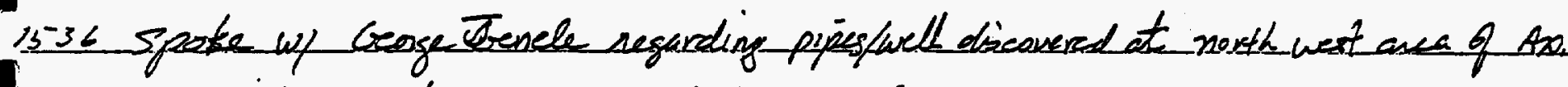
the said to speahe wh Herman Tery o 5-6543

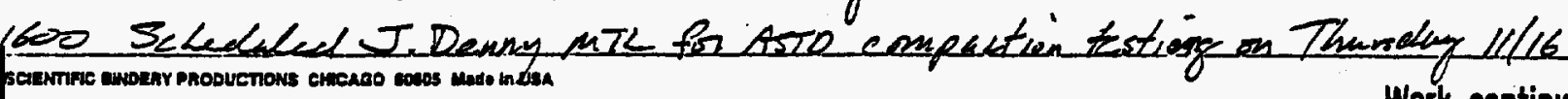

Work continued to Page N/A SIGNATURE

DISCLOSED TO AND UNDERSTOOD BY

DATE DATE

$111 / 14600$

Wminess

DATE 
TITLE CAUllo closure Aatinties

Work continued from Page N/A Wednesday $11 / 15 / 00$

Weatlu: Clear, cool 505 , calm
PROJECT NO.

BOOK NO.

79

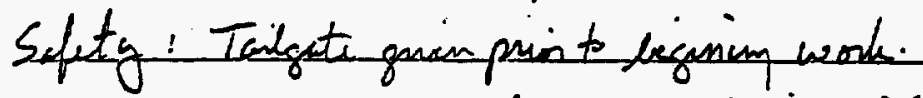

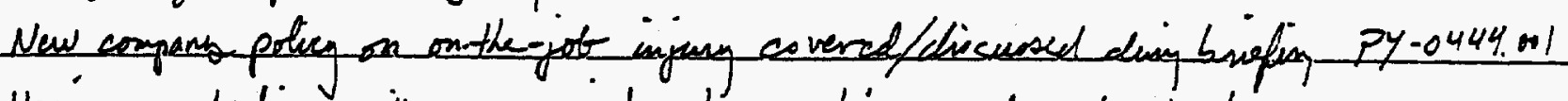
Hearing protection will er required when working aroused water truck.

visitors: Dore Krantzuitch - Iron workers GF ? Determined th *4 turn points need for Jesus Mange - Tronwarber J new fence line. on site untill 8:20 Bob Rome

- Continuing to place cover materiel on Ax/bl

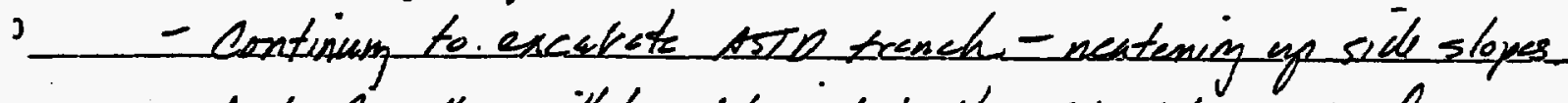

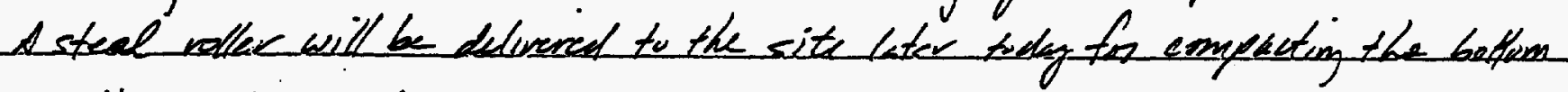
7 the Asti trench.

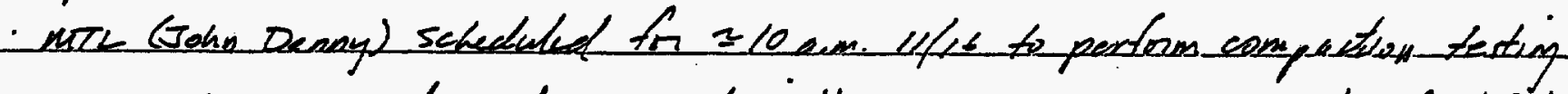

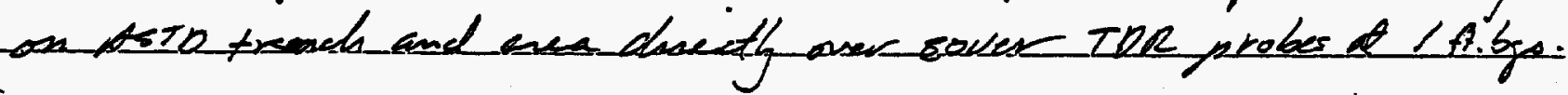

;

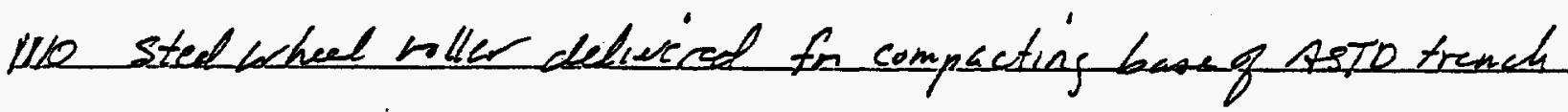

Ante Personnel

2 operators

1 laborer

2 ROTS C $7 \mathrm{~h}$ each

1 tech person

1 tea meter

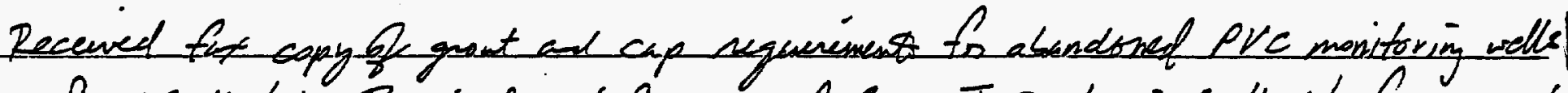

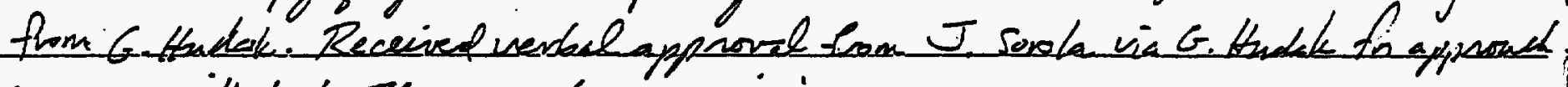

copy submitted to Roomer of BNEngining

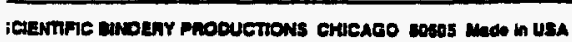

SIGNATURE

DISCLOSED TO AND UNDERSTOOD
Work continued to Page N/A

DATE

$11 / 15 \% 0$

WITNESS

DATE 
80 TITLE CAullo elosure Atisities

Work continued from Page N/A Thursedan $11 / 16 / 00$
PROJECT NO.

BOOK NO.

-Weathes: Cleas, cool folligit beceses from the var

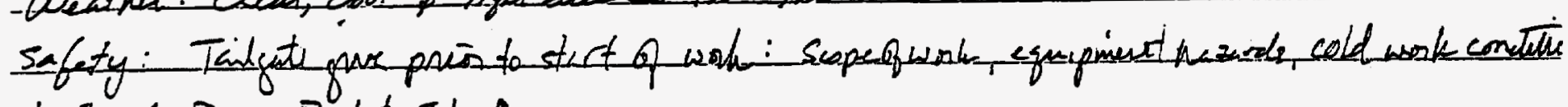

Visizors: Durese Puehd, John Dzey

- Continui to construnte astle cover i caver resanly compleke

- Compacting tosto tomed useng steel whert aller.

- Will constonct an test pad to duelope compantion performanue specs for sot by foot, $90 \%$ of $95 \%$ ung themper.

os40 Fust truch an site 2 teansters

Mecharie on site wathing belly dhupp that baoke down yestendey.

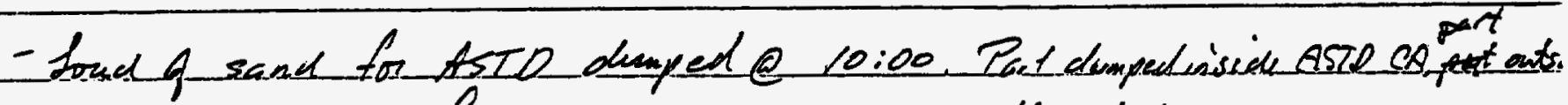
John Denry on site from Mr to do Asth campackien festing.

15 * Having trouble meeting compaction spes for sste pit bottom of 95\% Two appooaches (1) tsk engeneen to velex compaction spece to $90 \%$

(2) cellect a sample from pit fos a proctor G kyous will lit as collect a small semple for $\gamma$-sean condypis. If hase $\gamma$-sean isstriment at E-mad Have paygd Rich Deshlen $(4-5687,5-1090)$ aegerding

20 andyping semple.

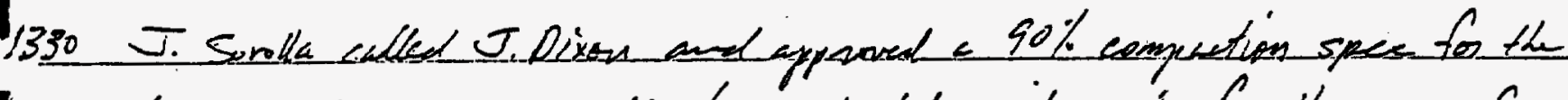

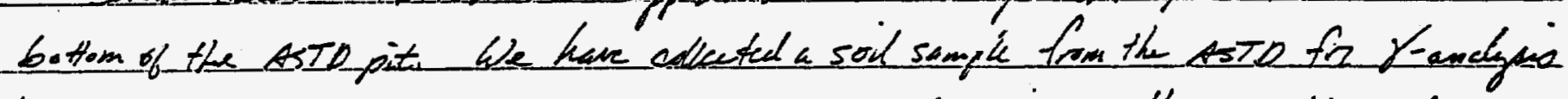

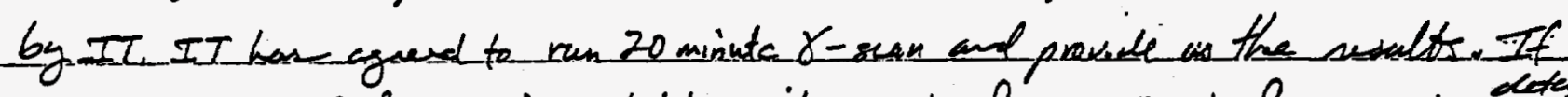

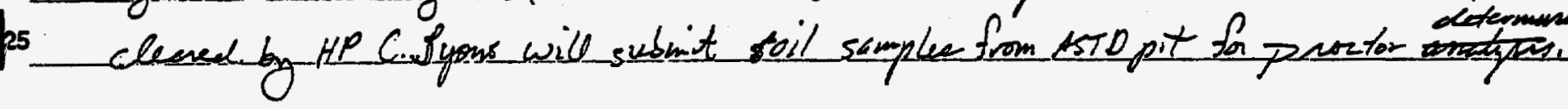

345 Comegated Metal Pips, \& of them, 10 ft dimmeter delvered to site and of loaded.

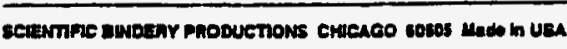

Work continued to Page 82

SIGNATURE

DATE

$11 / 16 / 00$ 
TITLE CAUIIO/ASTD Close Activities

PROJECT NO.

Work continued from Page 80 Thunder $11116 / 00$

BOOK NO.

81

funding to one hand here at thea 3 Ru

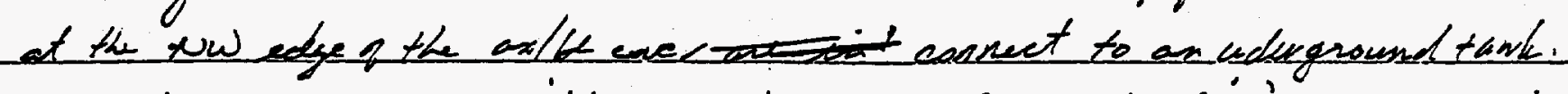
This tank wax possibly used to dispose of waste legends Was given a norse to check with - Norm Landing.

1410 Gary Noodle $\operatorname{Co} \theta$ was dispatched with Ass sail samples for sea 25 E-mad and r-andfyisis Sample botflesforere screened by RCT's and taken for analyzes

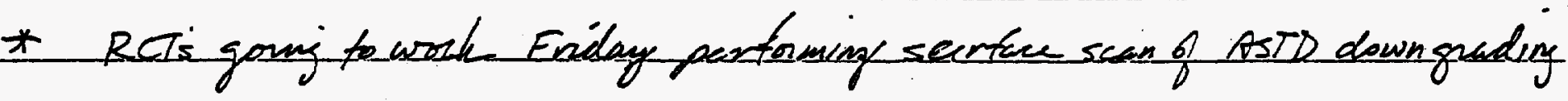
441 I Scroll called and apserved change of 95\% to $90 \%$ f compaction tor ASTD trench bottom.

15102 more CMP sections and sectolding anne on site and are of loaded.

1610 Bolo Cat consult on site, 3 yd

1615 Grain lyons called ad aftersevienving $\gamma$-spec sample results

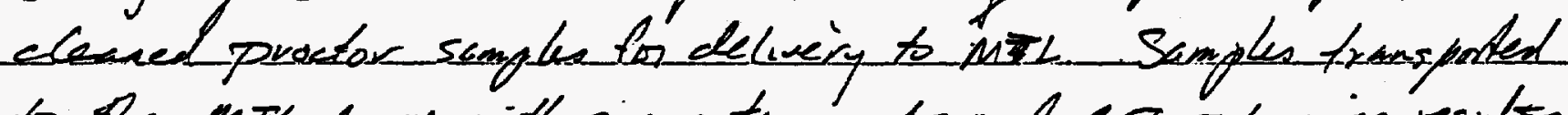
to the MTL by me with jensen tag and copy of eco rad swipe results

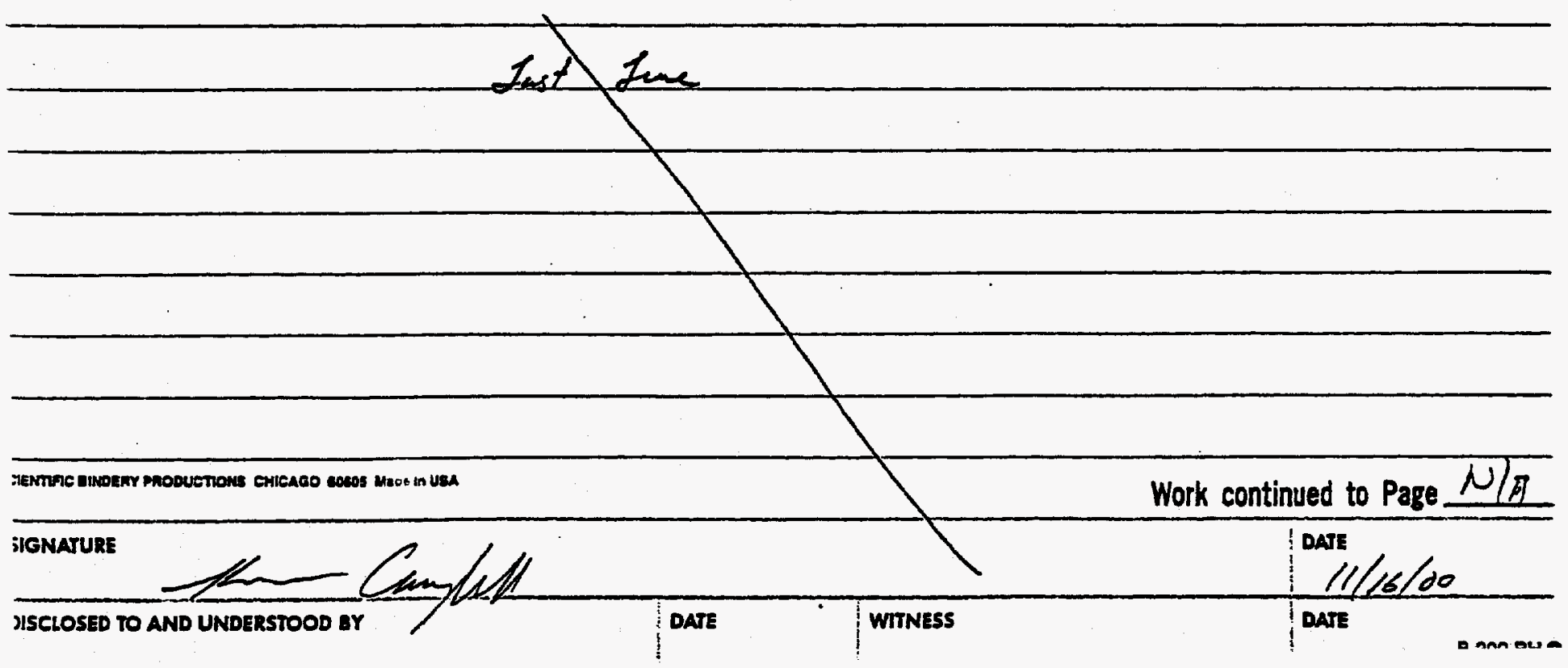


82 TITLE CAu $1 / 0$ Closure Actrities

Work continued from Page N/A Monday $11 / 27 / 00$

weather: High overcast, cod boi, edm.

Sofoty: Wok on pouring the bottens of AsTO lysinetes, working-asame hesery-equipment.

50830 SHIS0 perfoned atmosphenic survey of lymeter atmosp.

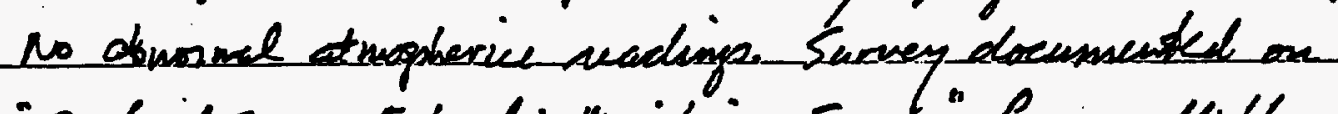

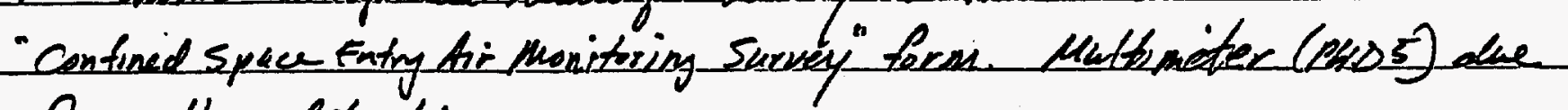
for montly calibration

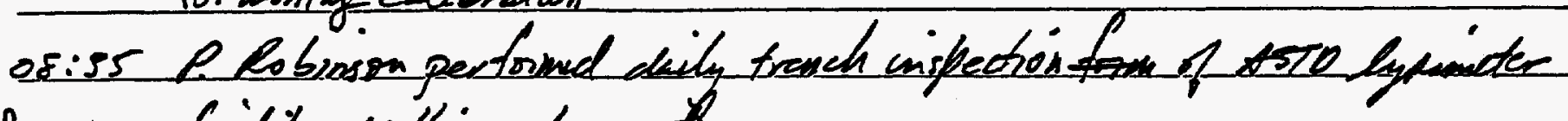
10 friling. Nothing abmocmate

ofion B6wers (2) weve delivered to site to provide ventibution in cans.

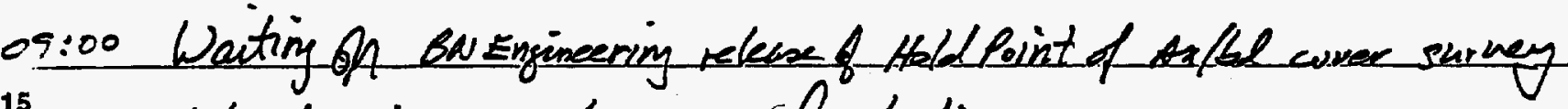
15 dete to rip coner to pospose fon plastion.

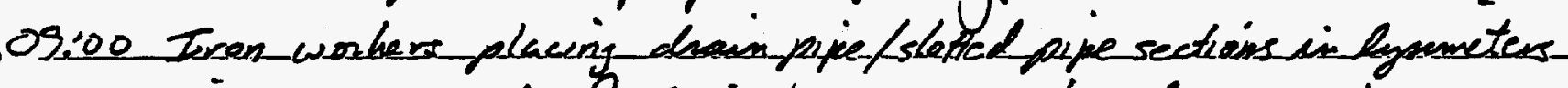
osios waiting concrete to lysimeter al atble fence port pur.

nosiso cement anvis on site

10ilo plaing cement in first lysimeter vio buchets

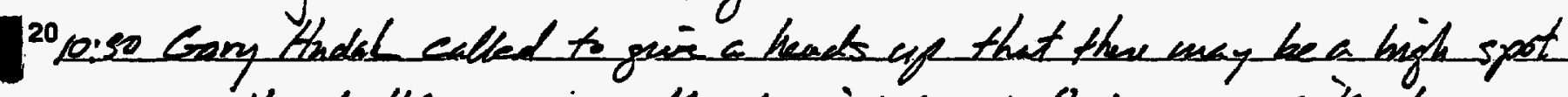
ron the Axflble coveiv. Aso te point stent that aver side slopes are shown at 10:1 andraiving.

Continuing to pour concrets in lysimaters

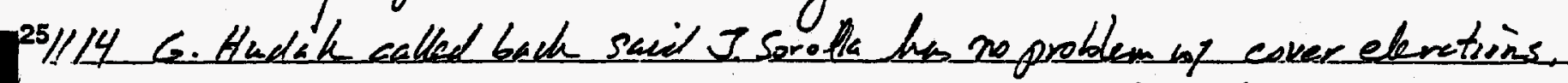

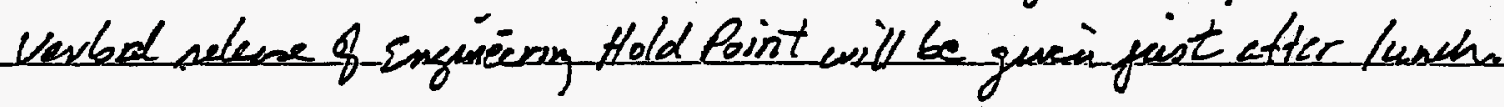

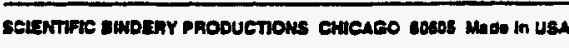
SIGNATURE

DISCLOSED TO AND UNDERSTOOD BY

complat

DATE

WITNESS

Work continued to Page 83

DATE

$11 / 27 / 00$ 


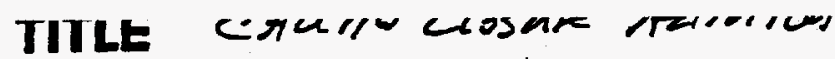

RKUJECI NU.

83

Work continued from Page 82 monday $11 / 27 / 00$

BOOK NO.

Visitors: FrenkEck,

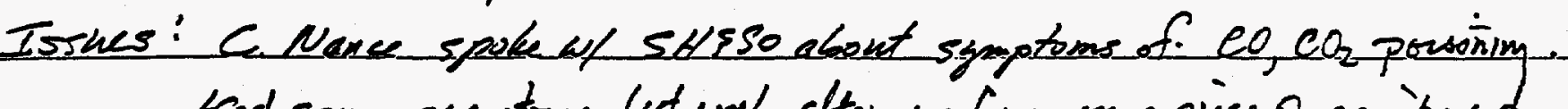

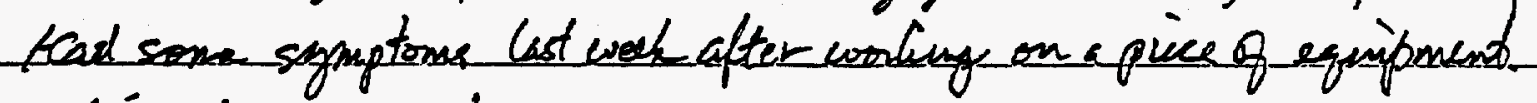

Ashing about symptoms of exposure:

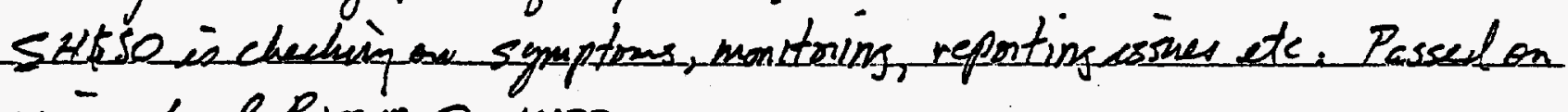
cosec to Brown a lli30

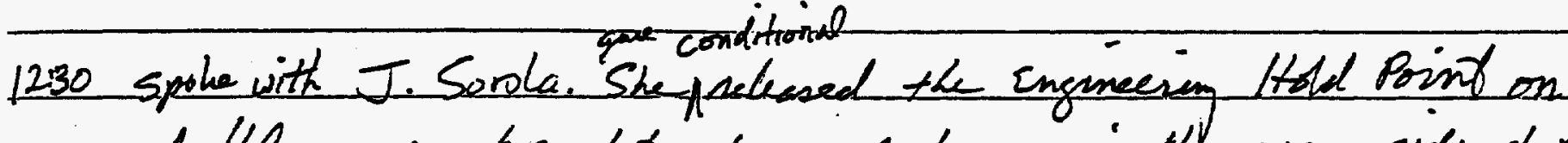
toll since tope date wee need to repair the cover side slopes to Lilo from present steeper stope. Whee can place subsidence monuments and began ripping for plating.

Conceded cover tee slopento pe:\%

5 Ripping cover to 6 inches using blade

Completed pouning-conerete and finsiking 6 lysimeter s,

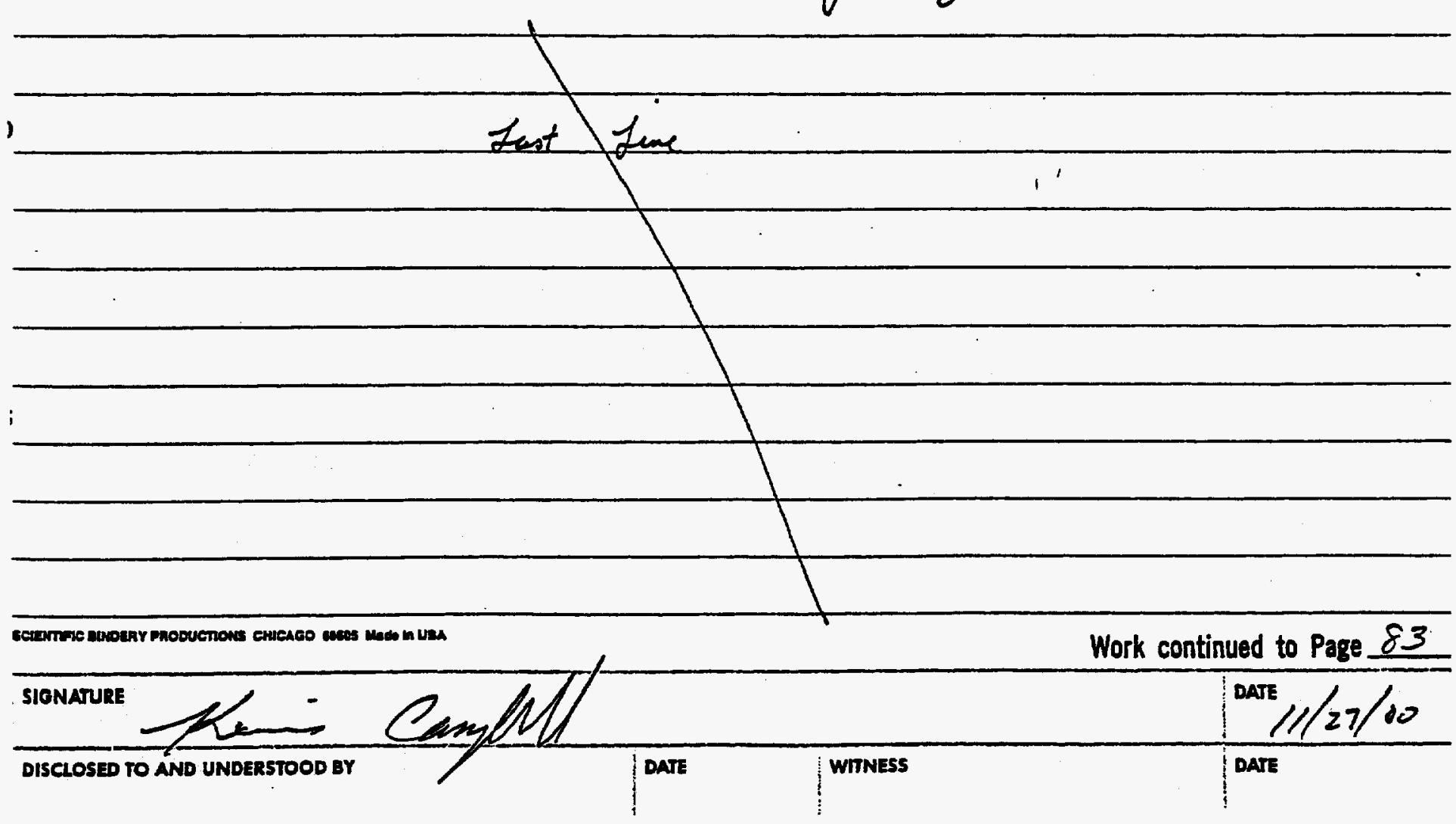


84 TITLE CAU110 Closures Activistic

Work continued from Page NA Tuesday $11 / 28 / 00$

PROJECT NO.

BOOK NO.

Weather: Clear, 60' calm

Safety: Tailgate given prion to word e

Visitor: Bob Rowel, 2 Fulas.

5

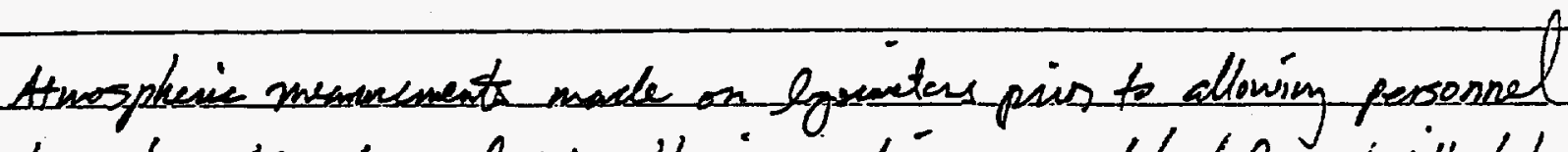
to enter. No brumal atmospheric reading were detected. Will take

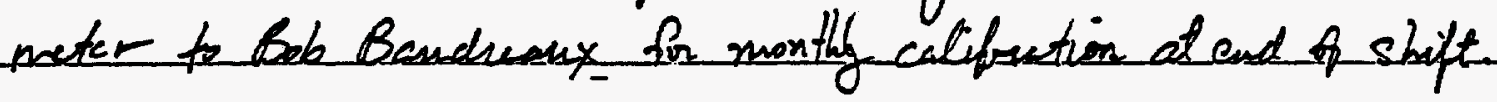

Off looking Tee port fo Ax/BO fence

10 Continuing :

Laying out Tee posts for Ax/ Be fere

zoo completed ripping the AnIse coser-with blade

1:33e completed placing cement in last lysimeter

15

P. Brown ordered voll-off for sita clean up

po

25

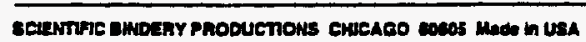

SIGNATURE
Work continued to Page N/S

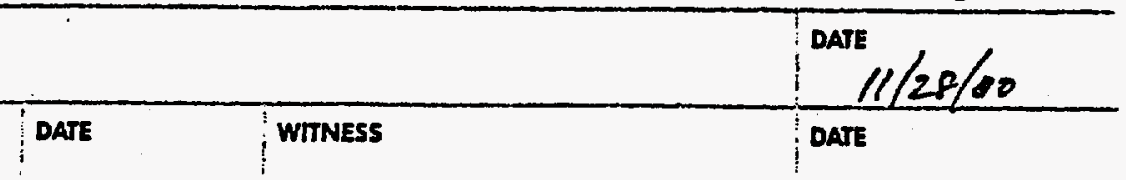


TITLE CAMIIU Clowire Actrition

Work continued from Page N/L Kususkag $12 / 4 / 00$
PROJECT NO.

BOOK NO.

85

Weather: Clen, suni, 70 's

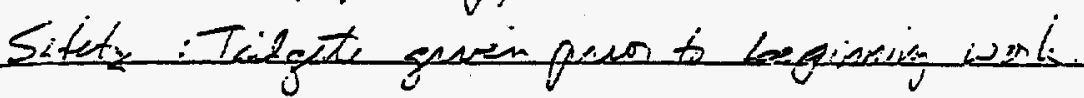

Visitnis: Sobini Cutis-ODE

Fed Zaferates - NDEP

5

Iate/slow start due to all hinds meting 2,5 hour deck

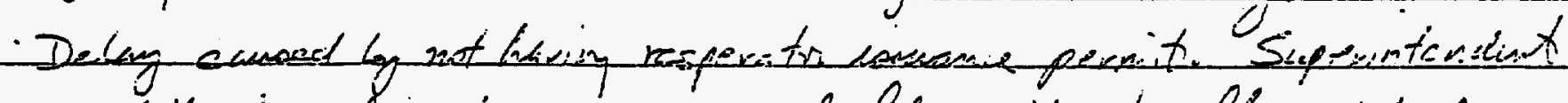
dut not recluge it wes eri grogat files did not ell tedilud.

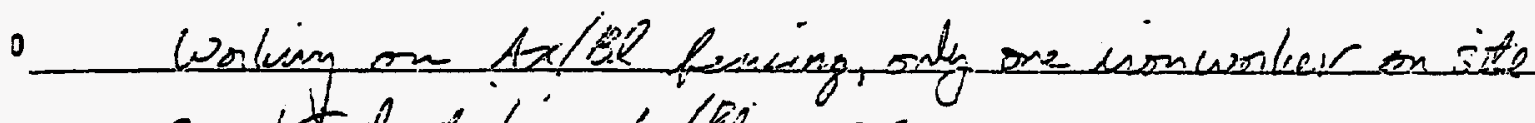

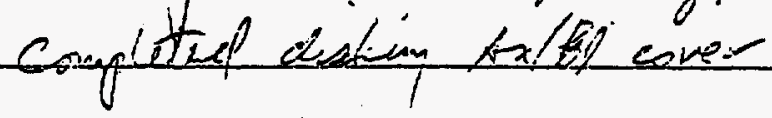

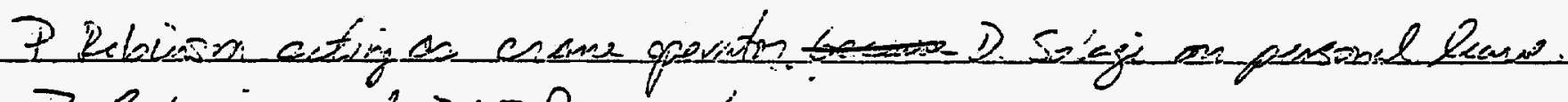

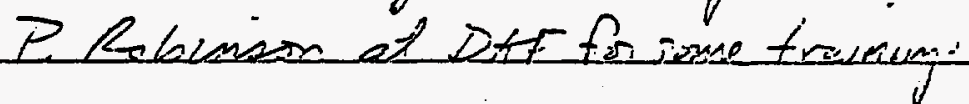

5

- Tresuged dinen vad soil pidi

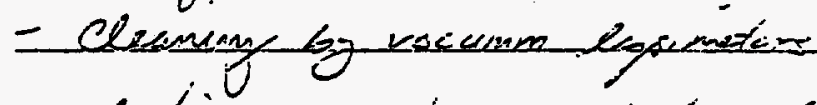

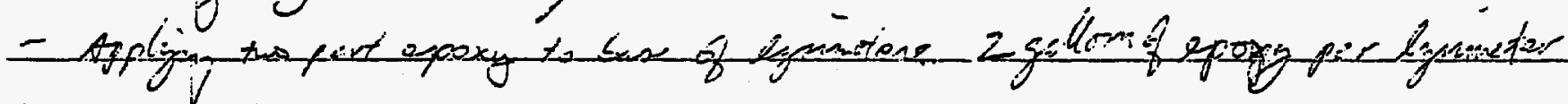

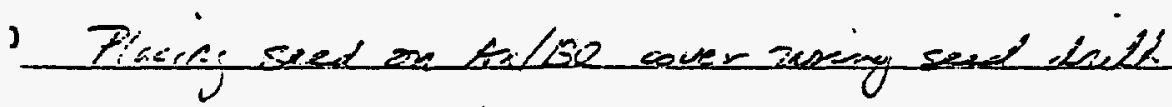

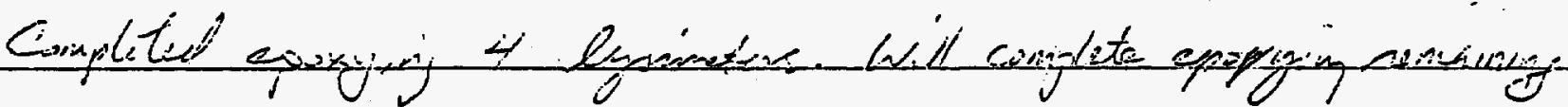

persers

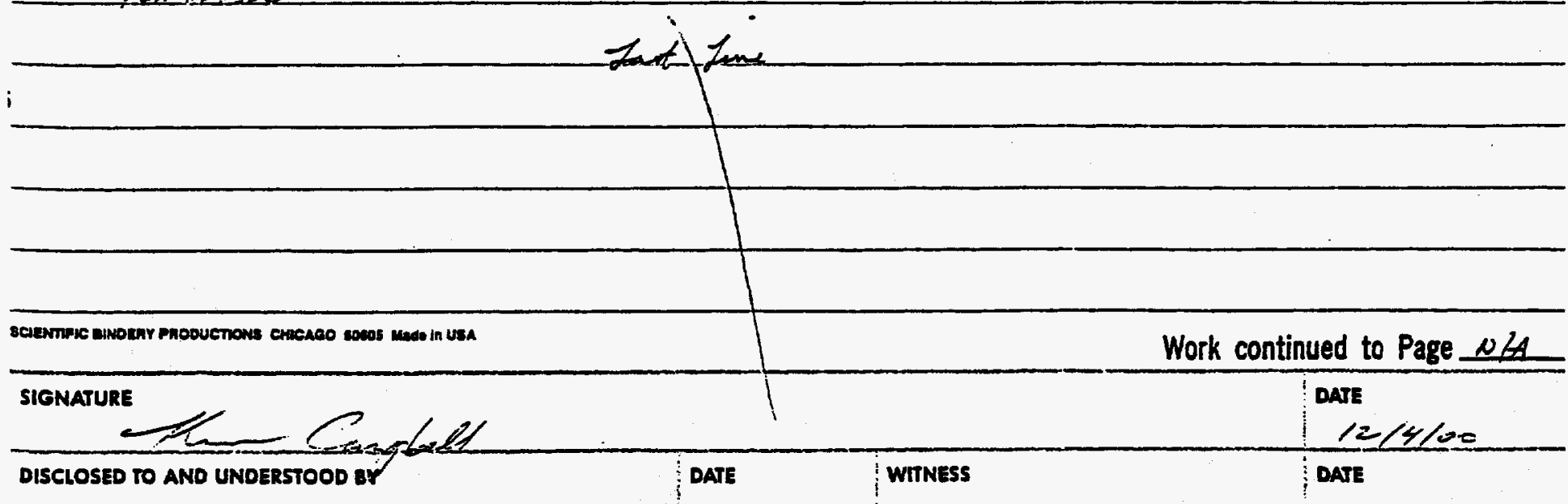


86 TITLE CAt 110 Closare Activitios

Work continued from Page 1Nix Tuesdiy $12 / 5 / 00$
PROJECT NO.

BOOK NO.

Weuther: Hif elands, fo's

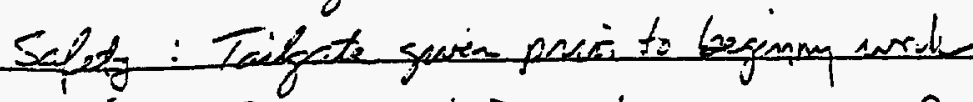

- Hisitus: Bob Rommel, Dure Kr

Dwaine focturt? Raterto Loger

Eupeneing to fluse strencon caver

5

ane temponity down theibinive sent tor.

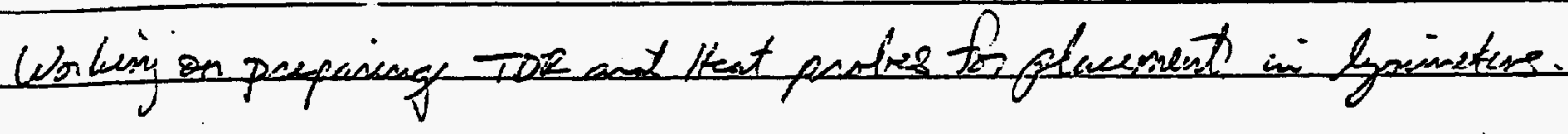

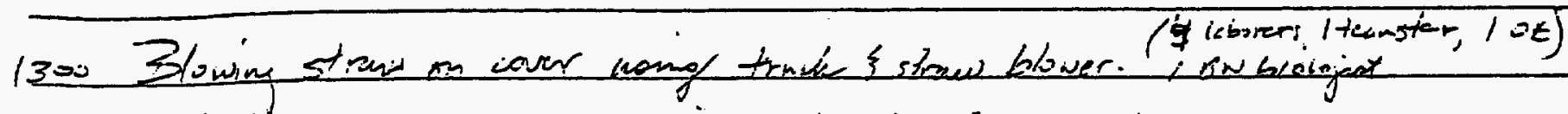

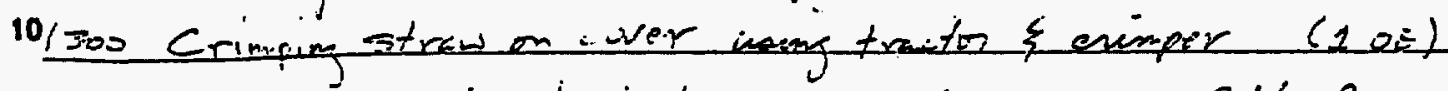

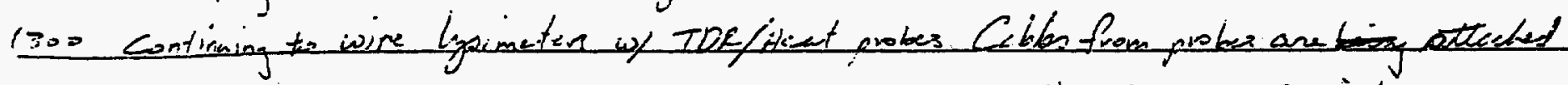

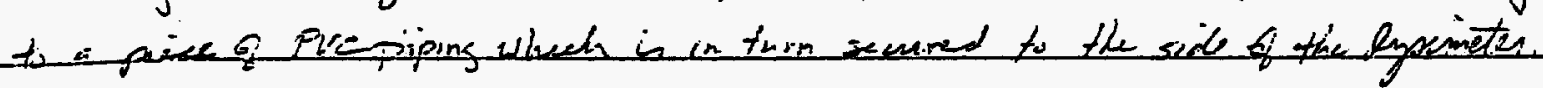

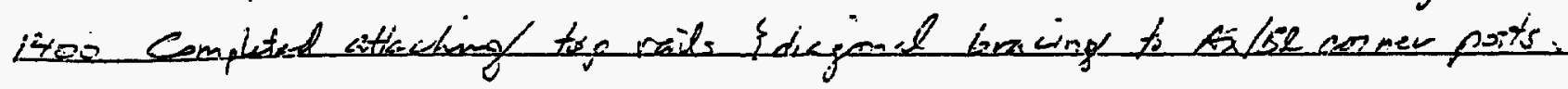

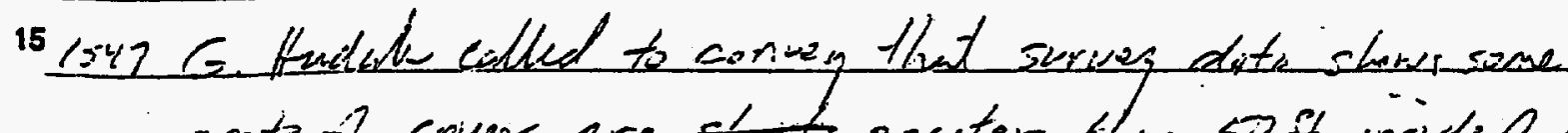

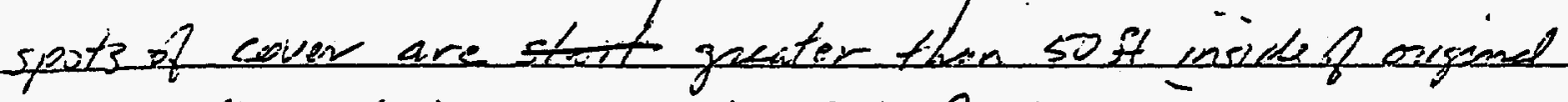

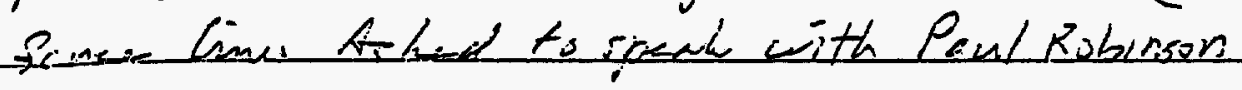

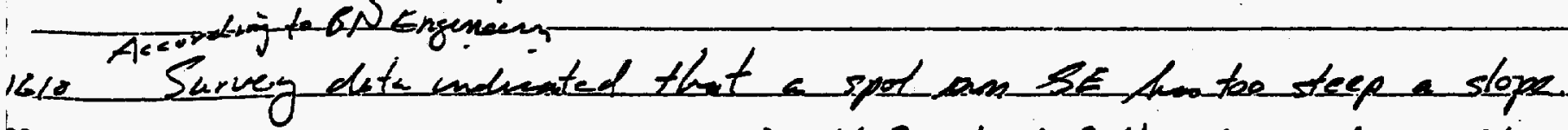

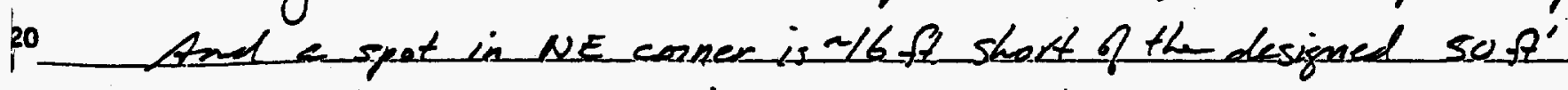
insith ovignal fense live Eng ashed that P Robinsos semsarme

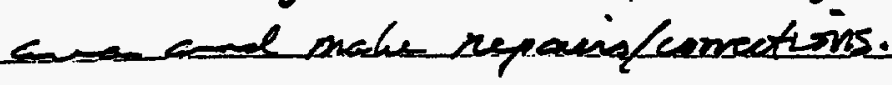

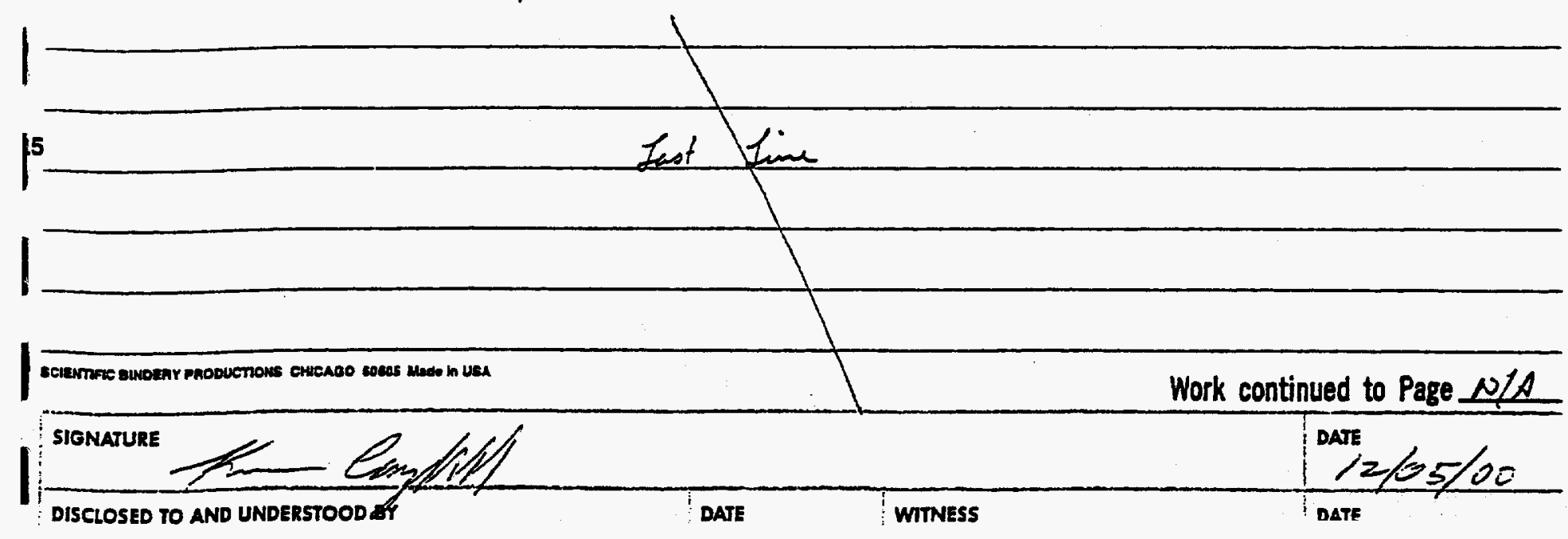


TITLE CAU110 Closure Activities

Work continued from Page N/A Wednesday $12 / 6 / 00$
PROJECT NO.

BOOK NO.

87

weather: Clear, bo $\mathrm{Calm}_{\mathrm{m}}$.

Stol: Tailgate given paine starting work.

Visitors: 2 feelers, (teamsters), teamster dropping of equipment

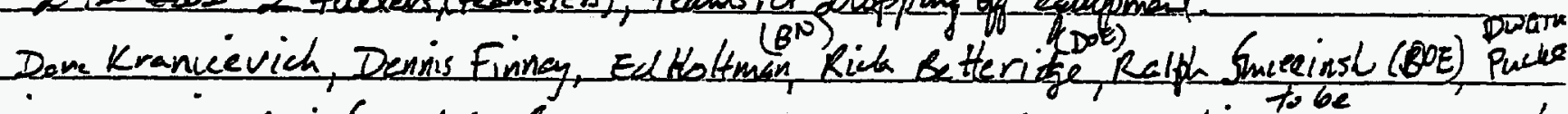

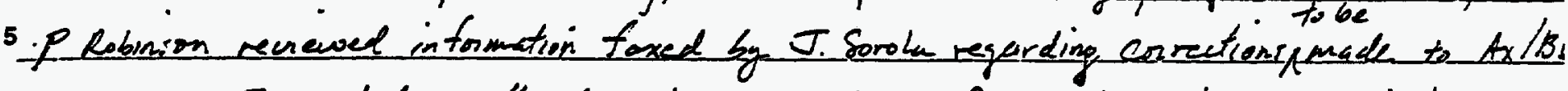

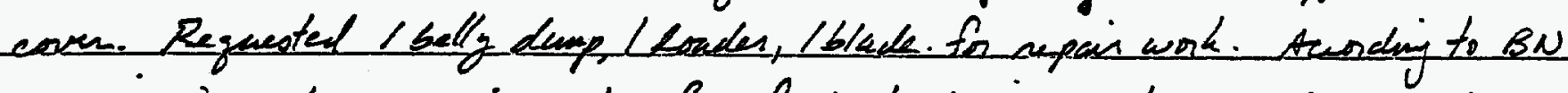

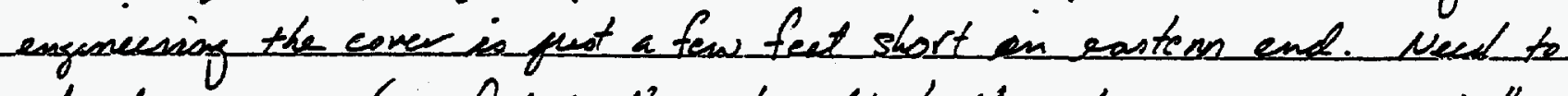
extend coves a few feet to the east, adjust the slopes to $10 \% 1$ on wallower.

- Continuing to run Tor/thed poke cables from lysimeter. Waiting epoxy to finish sealing last 2 lysimeter

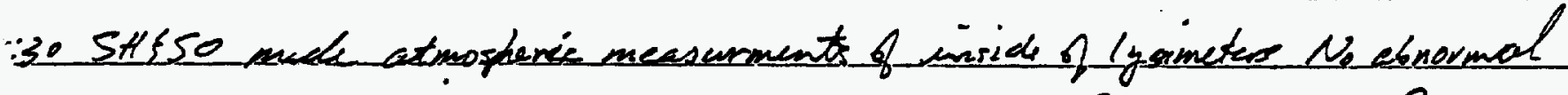

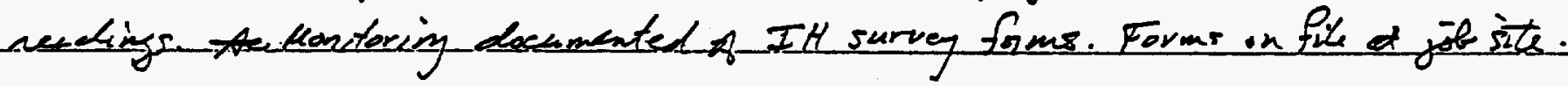

5

10:30 Blade lack en ad belly dump on site fo cover work. 11:00 Er it loud of fill from A3 borrow pit brought to caver.

- BNtechnesin testing TOR Stent probes.

- Electrician continuing to instalf/secure Probes f cabling.

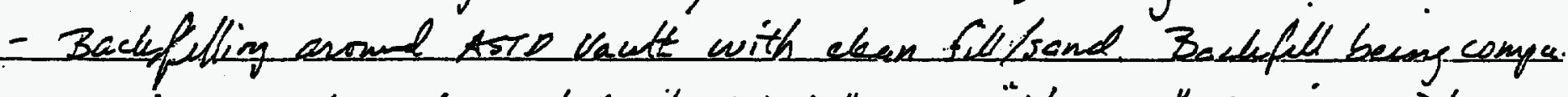
using hand panted vibrating roller and "thumped" tamping units. Mechanic working on 2 thumped nonet.

- continue to blew and crimp straw on cover.

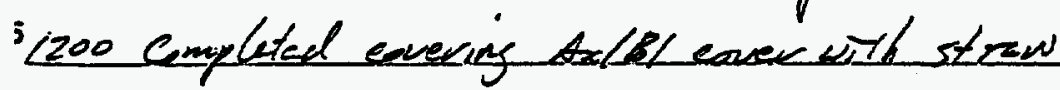

Repositioned the cause so that it can be used te lift buret bonds of dint int the tick trench.

Dan Levit on site to test TOR temp probes in Sysindees, Ales chechen cover TD R pis

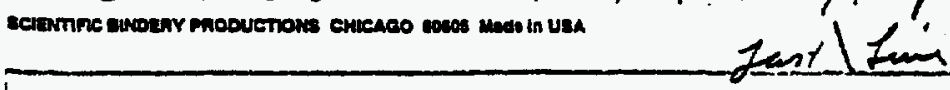
Work continued to Page N/A

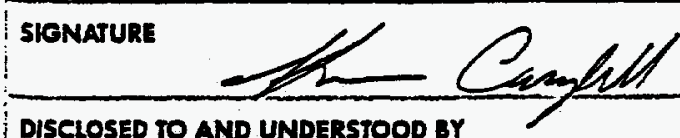

DISCLOSED TO AND UNDERSTOOD BY

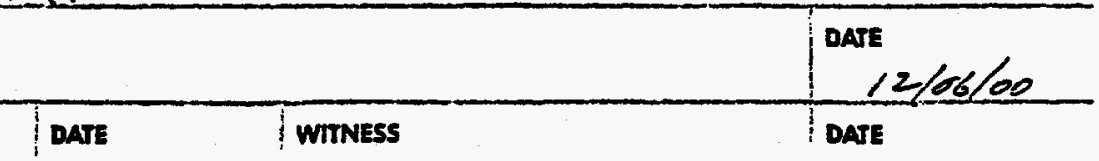


88 TITLE CAUI10 Closure nativities

Work continued from Page Nile Thursday $12 / 07 / 2000$
PROJECT NO.

BOOK NO.

Weather: High elands, 60', calm

Safety. Tailgate guin psis to beginning work.

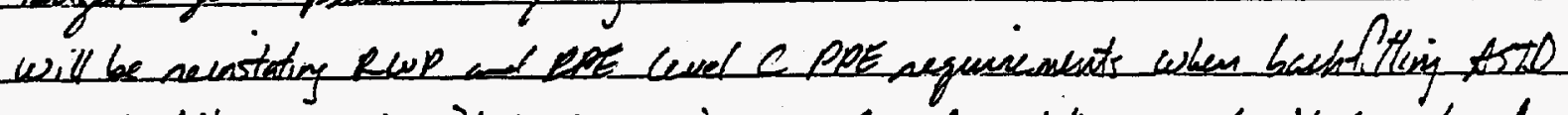
trench with suspect soil. Rus will be entrees en till suspect soil is placed,

5

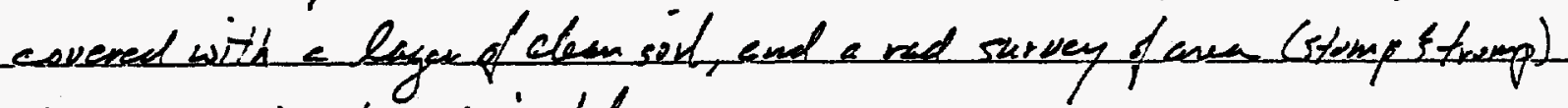
shows as e in not ante minted,

'Visitors: Craig Lay os

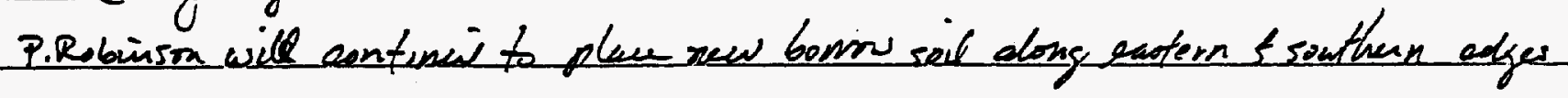
of Aloe cover.

10

Space with Mace bandy regarding what soil was wad in the instruction of the Axial cover. Wis idly soil from that and excavated from between Ax BBl. Tom Comers was also involved with Axle corer construction.

15 Dy severe spade hobs along easter edge of cover near th 50 ft lint. Hill show that then is (ft n more of cover material over the oscine

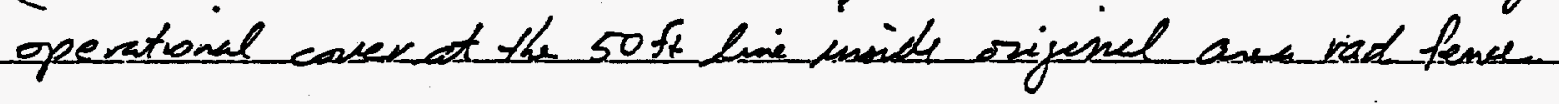

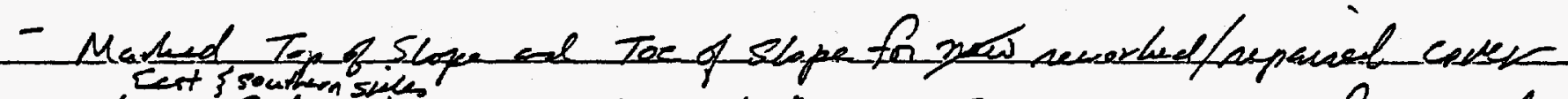

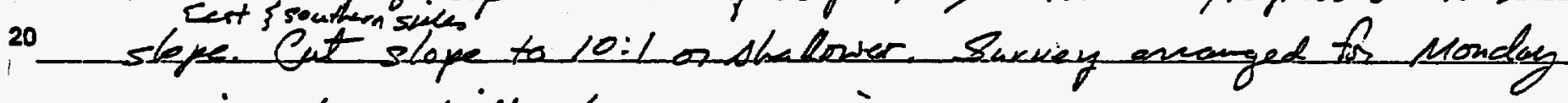
morning to os-bwilt slopes once again.

- Ironworker cut up one se moved gate returned incorrect wire bash to warehouse.

PS

- No earth work on ASTD dou e tody

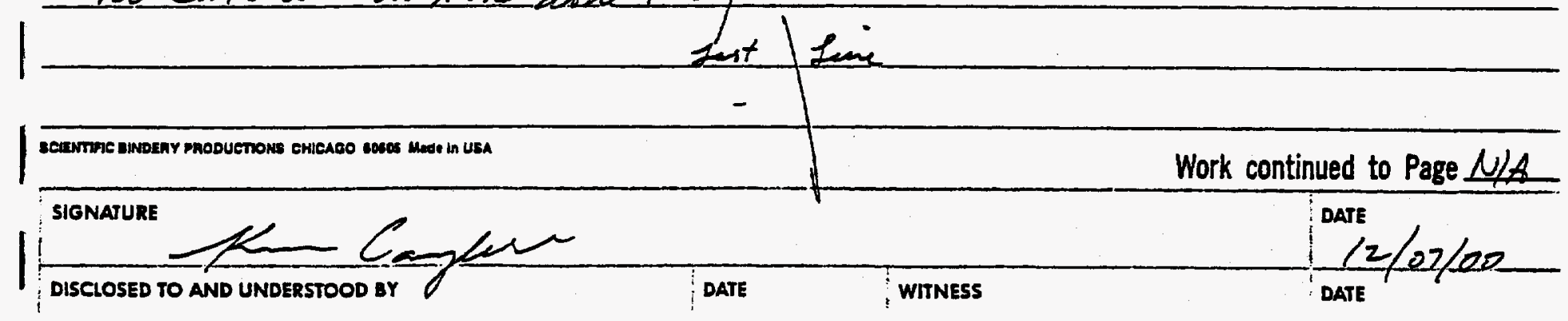


TITLE Coulso elosure Actiritis

Work continued from Page N/A Mondey R/111/20000

Weather: Cold so's clear calm.
PROJECT NO.

BOOKNO.

84

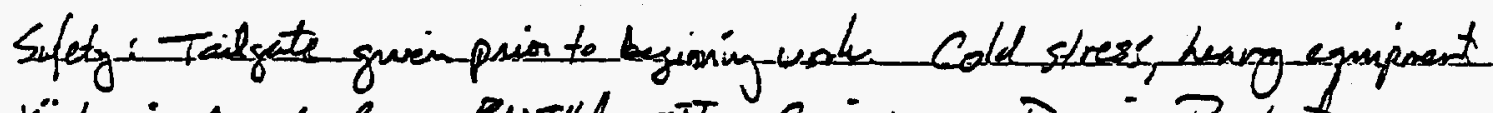

Vistor: Angela Ray BNIIfor OTT, Caijhyous, Dupine Puelet

5 - Survey on itt to resurvey Ax/Bb top-of slope and toe of slope; monument locations and as=buite fence

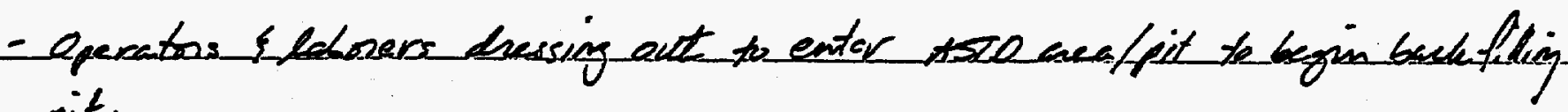
pit.

10

- erone dewn mechanis callel crane sreak will not selease.

11 ise thecharimen site to repais crane.

Crane sepeasid. Bachfelthy Aszo pit.

5 - Sunvezosi placing bress pins in subsidence monuments on tx/te. They completed as-6miting swriey of the new fence, the cover ectes

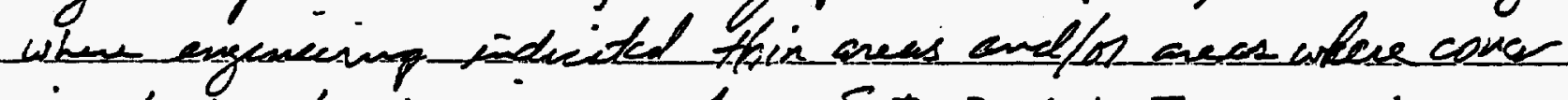
is short not axtensive enoyth. Set 3 of the 7 Grass pins-in. subsidence monument Batteries on drill went desh. Deta delweried to seoty Ellewen at apporx noon.

- completed plaing firit If lift in Asto trench Compation of lift

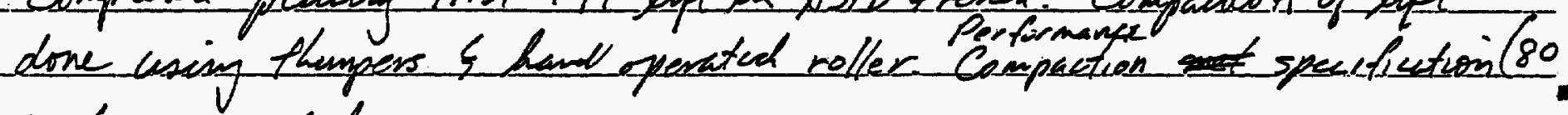
inct on exceeded.

i- Dust controlled by watering.




90 TITLE canllo Closure Actioitiso

Work continued from Page_N/A Twesday 12/12/00
PROJECT NO.

BOOK NO.

weather : Overcast, cold 50 's, calm, scattered showes, hail, gusty witids

safdy: Tailgate gwien prin to beginnig work

Vusitres: Von Moll RSL photographer, Geleu Messer

5

Slow stant to ASTD divt wob due to ligh prespitatien

p:00 Loboers is Astopit comparting lift.

Mechanicen site coolian on crane

10:30 Erane still hwing psoblems. Mechenic called bechto site llsing-coner withent swing brake.

10 Plaving lift in ASTD \{ compating cosing thempers \& roller

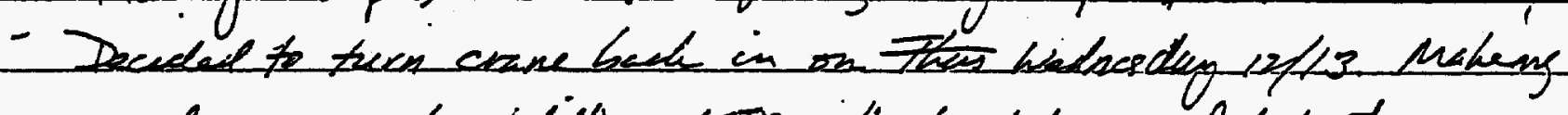

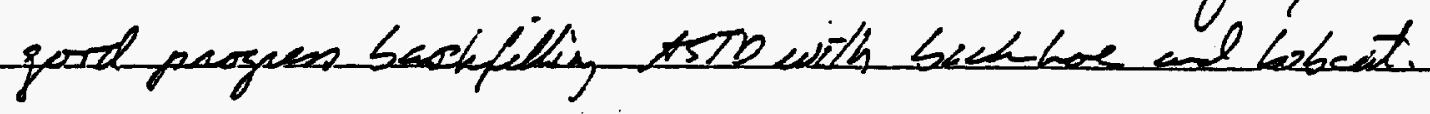

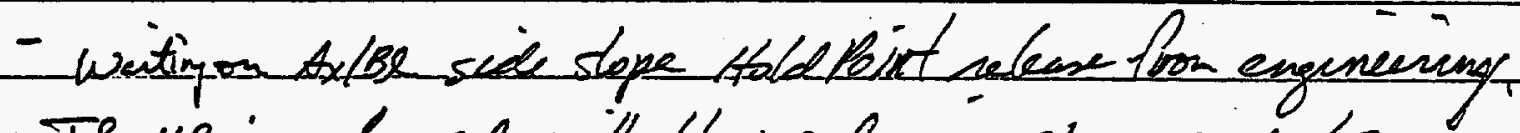

15 - If tif is rebensed will blow and caing straw $m / 2 / 13$ on cover ectges.

RCTS suveying the crene hook for sekase. swipes of crane took show ne rad. Crane released fur demolalization 1

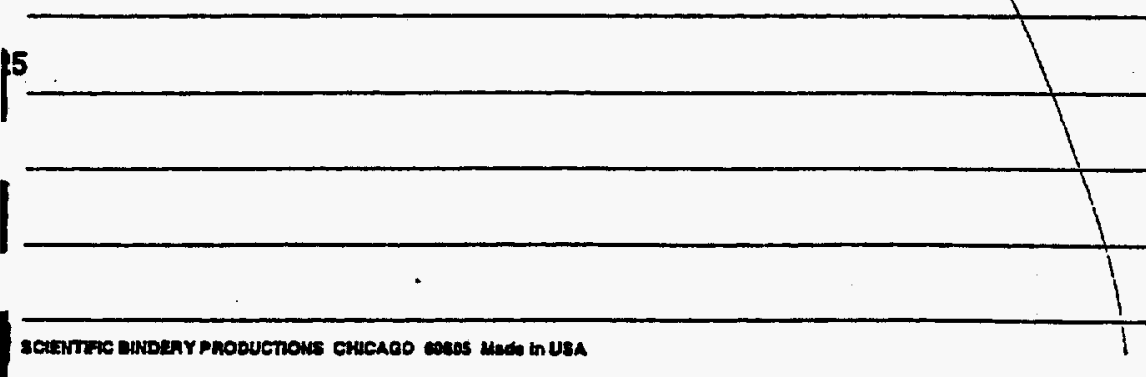

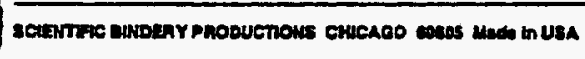

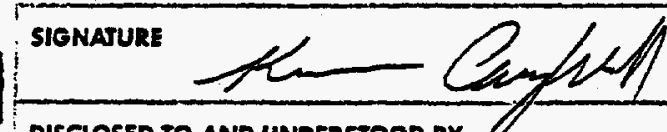

DISCLOSED TO AND UNDERSTOOD BY

DATE

WITNESS

Work continued to Page N/S

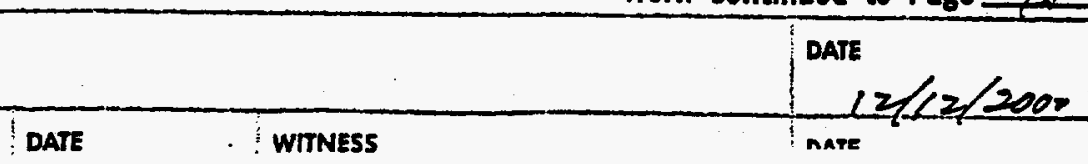


TITLE CAul10 Closure Activities

Work continued from Page N/A wedneselay $12 / 13 / 00$

wenther: cold 50 ! high clouds, calm.

Sefety: Tailgate goven prin to beginning wak

Visitors: Riel Simith. Boin Rommel

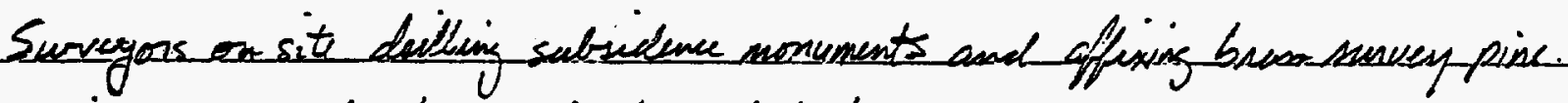
will sunvey and stamp pias by exl of the day.

Grew fo stawe lawing on hand - loperaton, 2 laboness.

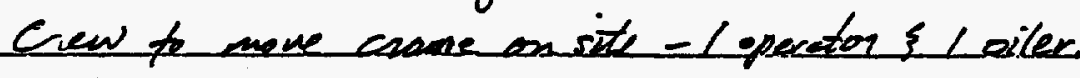

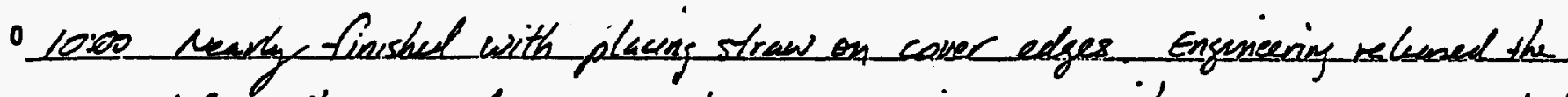
He on the cover edges on 12 liz o 1730 vie an email messge. Strow will becomped nite place.

- Contineing to bechfill AsID fxench. Jay Dxan anved on sith with the semain 5 of the hect parese for the fysmeters.

ROT prepering to take divty leundry to landry

Crane demobalased from gith.
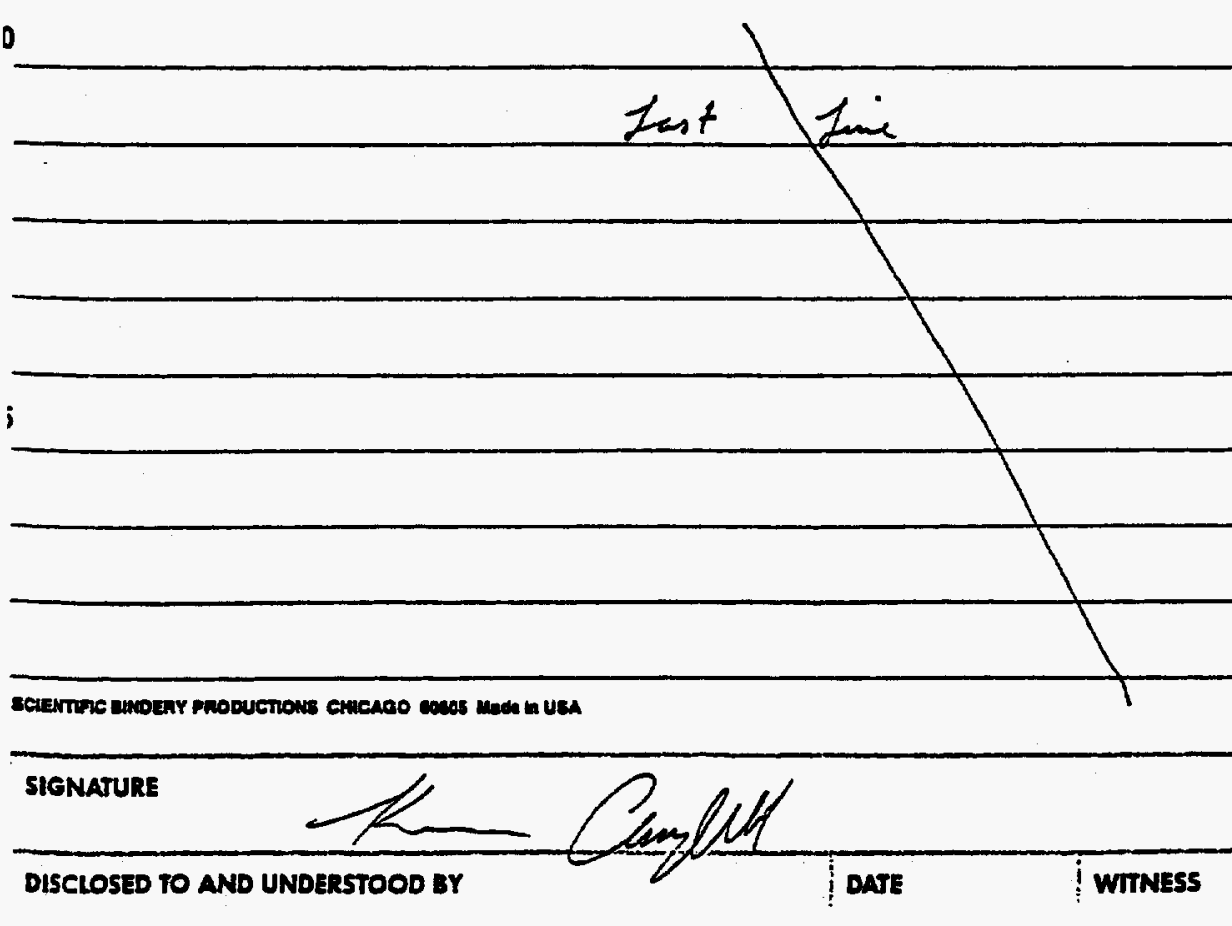

Work continued to Page 
92 TITLE CAuslo Closure Aotivition

Work continued from Page N/A Thursdy $12 / 14 /$ oo
PROJECT NO.

BOOK NO.

Weaties: clear, cold 50; light wends

Sffty : Twigets gines pus to beginning watk.

Visitros: Frank Eck teanster GF, 2 Euchers, 2 oilers

5 Continuini, to bach fill asse tranch from soil pile

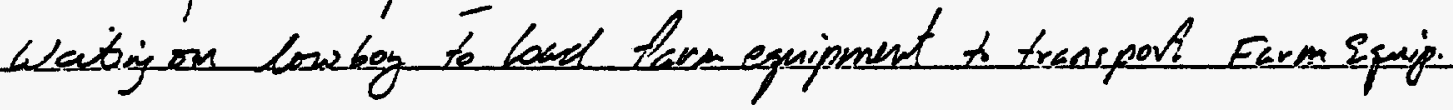

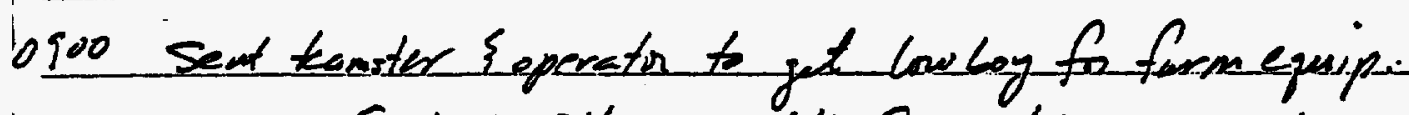

Y:000 sunvey finwhed with as-6will of sx/Be monuments $10 / 4: 30$ second lond of ferm equepimat to Mercury.

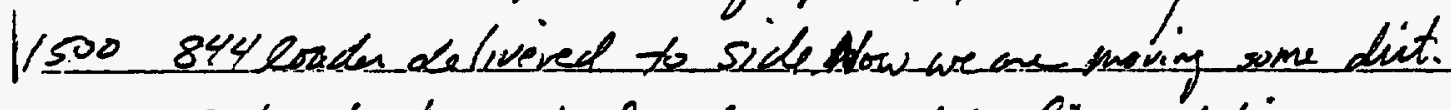

1520 Tenker track emptyed ad secturned to flling station

1530 low boy of to flect. Skond be of rent as $6 / 2 / 14$ CB

1530 Completel pluing all suspeted emtaminated soil in ASTO to pit.

Covering Asto whom with "aleon" soil from excevetion pila.

1600 R cruse had to attent a secunt brafing

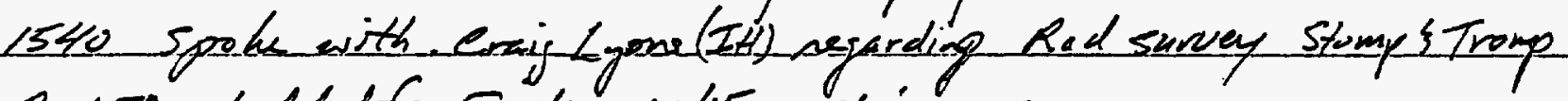
of Aoth scheduld fir Fridy $12 / 15$. It is a go

b

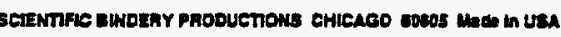

SIGNATURE
Work continued to Page N/A DATE $12 / 14 / 100$ 
Closure Repon - CAl: 110

Section: Appendix $\mathrm{H}$

Revision: 1

Date: August 6. 2001

THIS PAGE INTENTIONALLY LEFT BLANK

a 
Closure Repon - CAL 110

Section. Appendix

Revision: 1

Date: August 6. 2001

\section{APPENDIX I}

\section{U-3ax/bl TDR CALIBRATION}


Closure Report - CAL 110

Section: Appendix I

Revision: 1

Date: Augusı 6. 2001

\section{THIS PAGE INTENTIONALLY LEFT BLANK}




\section{U-3ax/bl TDR CALIBRATION \\ Conducted March 2001 \\ Dan Levitt, Environmental Technical Services, Bechtel Nevada}

April 4, 2001

Introduction

Calibration of time-domain reflectometry (TDR) sensors is required because soil type affects TDR response, and because TDR trace length (and subsequent volumetric water content) measurements increase as cable lengths and numbers of multiplexers increase. A "dry-down" calibration was conducted on a TDR probe in a laboratory in March 2001.

Results indicate that a linear equation fit the calibration data with a correlation coefficient $\left(R^{2}\right)$ of 0.9963 , which is an excellent fit. The calibration data fell just far enough away from standard calibration equations such as Topp's equation (Topp et al., 1980), that it is recommended that the site-specific and cable length-specific U-3ax/bl linear regression equation be used. A $2^{\text {nd }}$ order polynomial equation was also fit to these data $\left(R^{2}=0.9966\right)$, but the gain in accuracy is so slight, that a linear regression equation should be used for simplicity.

\section{Calibration Procedure}

[Note: A BN Draft Procedure is currently being prepared, but has not been formalized yet.] A bucket of soil was collected from the U-3ax/bl cover in November 2000 . Soil from that bucket was placed in a flat pan with dimensions of $52 \times 26 \times 7 \mathrm{~cm}$, with one Campbell Scientific Inc. (CSI) TDR probe model CS610 buried horizontally in the middle of the pan. The probe had $2 \mathrm{~cm}$ of soil above and below the probe rods. The TDR probe had 165 feet of RG8 cable, and was wired through a level-two SMDX50 multiplexer, with 10 feet of RG58 cable connecting to the level-one multiplexer, with 1.5 feet of RG58 cable connecting to a TDR100 TDR controller. This configuration is identical to the two $U-3 \mathrm{ax} / \mathrm{bl}$ TDR system configurations.

The soil pan was placed on an electronic balance for NIST-traceable mass balance measurements. The electronic balance was configured such that its digital output could be logged by an analog datalogger as TDR measurements were made, providing a dataset of TDR measurements of trace length divided by probe length $(\mathrm{L} / \mathrm{L})$, with simultaneous measurements of mass.

After initial setup. the soil pan was saturated, and left to dry for two weeks. After drying to a final volumetric water content (VWC) of $5.5 \%$, the soil from the soil pan was weighed, ovendried for 24 hours, and weighed again to determine final VWC. This "anchor point" was used to convert mass balance measurements into VWC readings, and compared to $L / L$ measurements made by TDR. 
Results and Discussion

Results from this dry-down calibration are shown in Figure 1. Due to the long cable lengths and soil type at $[\mathrm{T}-3 \mathrm{ax} / \mathrm{bl}$, the TDR trace end-points were extremely flat under saturated, and nearsaturated conditions, rendering the TDR data unreliable under such conditions. Therefore, the TDR data was only fit through a VWC of $30 \%$. Fortunately, only the top few centimeters of soil at $U-3 a x / b l$ is expected to get this wet (following significant rains), so the use of a TDR calibration in the range of 5 to $30 \%$ volumetric water content should be sufficient. The noisy data at the rvet end of this calibration are shown in Figure 1. Figure 2 is the same as Figure 1, but with Area 5 , and CNTA TDR calibration data included for comparison.

A linear equation, and a $2^{\text {nd }}$ order polynomial equation were fit to the U-3ax/bl data using linear regression data analy'sis tools in MicroSoft Excel. The correlation coefficient $\left(R^{2}\right)$ for these fits were 0.9963 for the linear equation, and 0.9966 for the $2^{\text {nd }}$ order equation. There is essentially no difference between these equations, so it is recommended that the linear equation be used for simplicity.

If the calibration data were closer to one of the standard calibration equations, such as Topp, Topp's equation could be used for simplicity. However, the U-3ax/bl TDR system configuration uses the longest cable lengths known to be used by staff at CSI (Jim Bilskie, CSI, Personal Communication). If the Topp equation is used, VWC will be over-predicted by about $5 \% \mathrm{VWC}$ (at a VWC of $25 \%$ ).

This method does not account for hysteresis. However, field soil is usually in a drying state, with wetting only occurring following precipitation events, and the error associated with hysteresis is generally a few percent VWC. In addition, this method of calibration is recommended by Campbell Scientific Inc., and by researchers at several Universities who use and calibrate TDR regularly (Jim Bilskie. CSI, Personal Communication).

\section{U-3ax/bl TDR Calibration Equation}

Results of linear regression analysis yielded the following table of coefficients:

\begin{tabular}{|ll|}
\hline Intercept & -17.13722 \\
XVariable 1 & 10.373701 \\
\hline
\end{tabular}

Such that $\mathrm{VWC}(\%)=-17.137+10.3737 *(\mathrm{~L} / \mathrm{L})$

Where $(L / L)$ is trace length / probe length and output by the datalogger.

\section{References}

Topp, G.C.. I.L. Daris and A.P. Annan, 1980. Electromagnetic determination of soil water content: Measurements in coaxial transmission lines. Water Resources Research 16(3):574-582. 


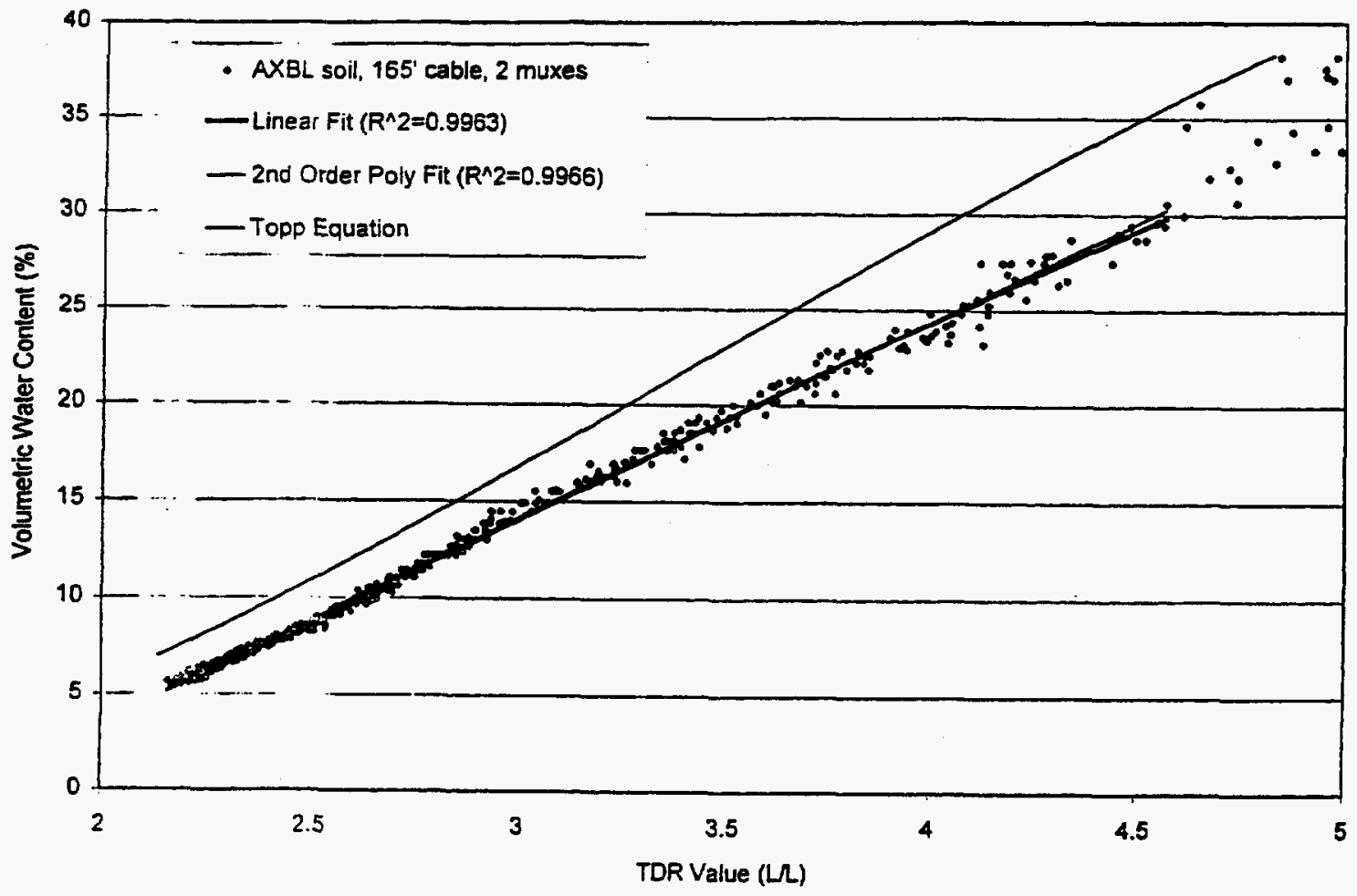

Figure 1. U-3ax/bl TDR calibration fits with the Topp Equation.

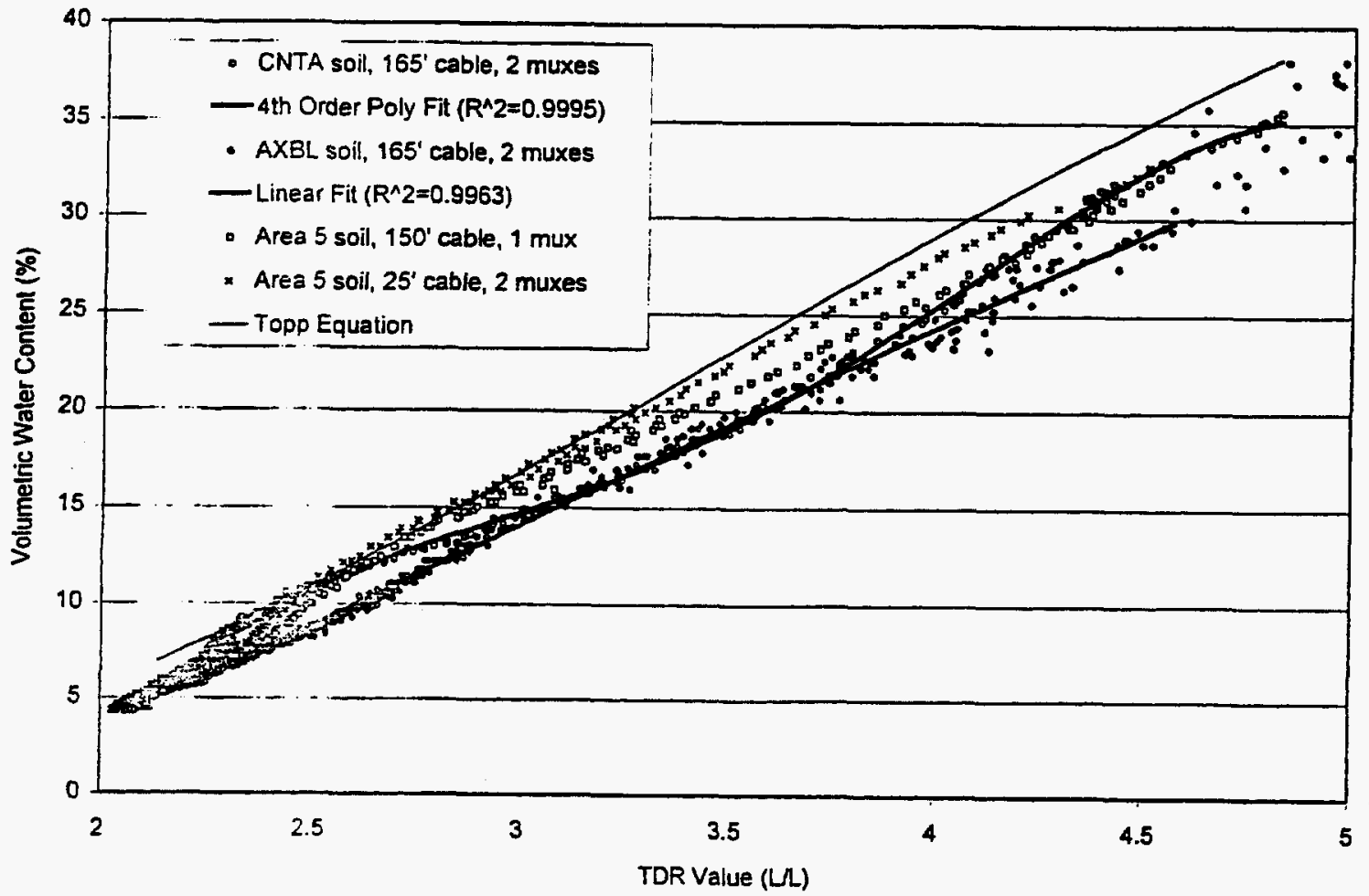

Figure 2. $L-3 a x / b l$ TDR calibration with other calibration data and equations. 
Closure Repon - CAL 110

Section. Appendix I

Rerision: 1

Date: August 6. 2001

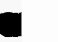

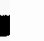

THIS PAGE INTENTIONALLY LEFT BLANK

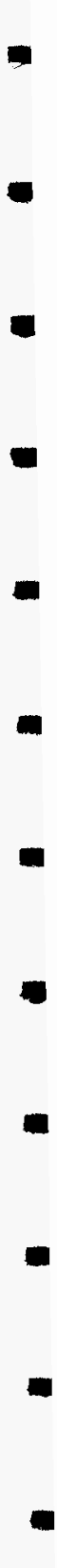

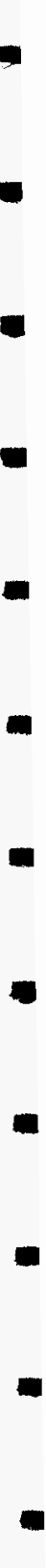

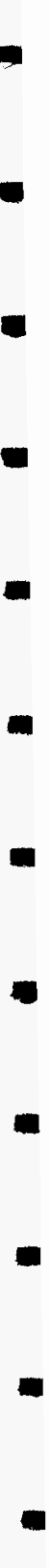

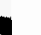

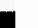


Closure Repon - CAL 110

Section: Appendix J

Revision: 1

Date: August 6. 2001

APPENDIX J

NDEP COMMENT RESOLUTION 
Closure Repor - CAL 110

Section: Appendix I

Revision:

Date: August 6. 2001

THIS PAGE INTENTIONALLY LEFT BLANK

ש 


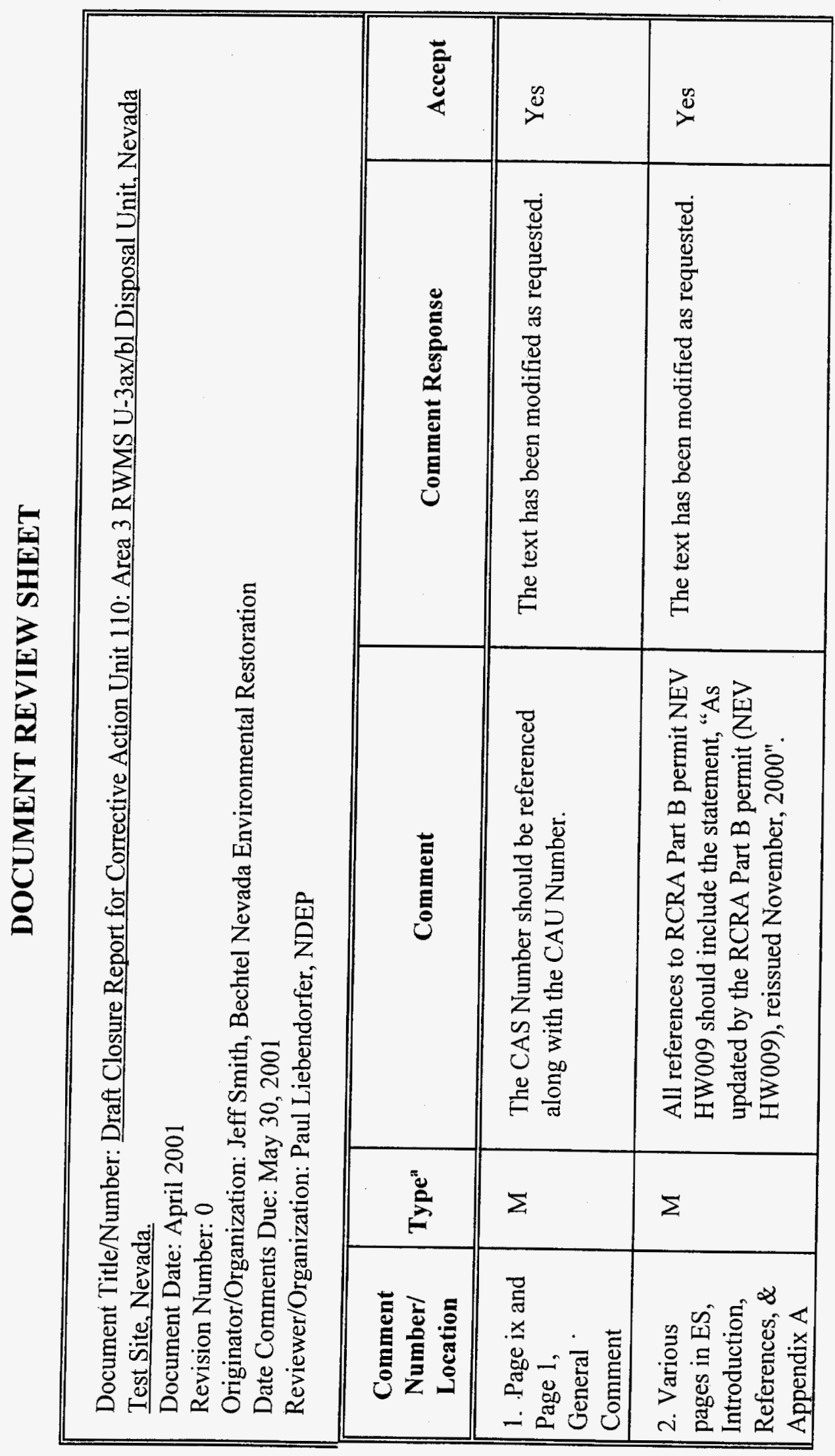

$\square$
4
$\frac{0}{0}$
0
0

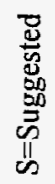

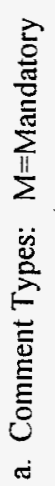




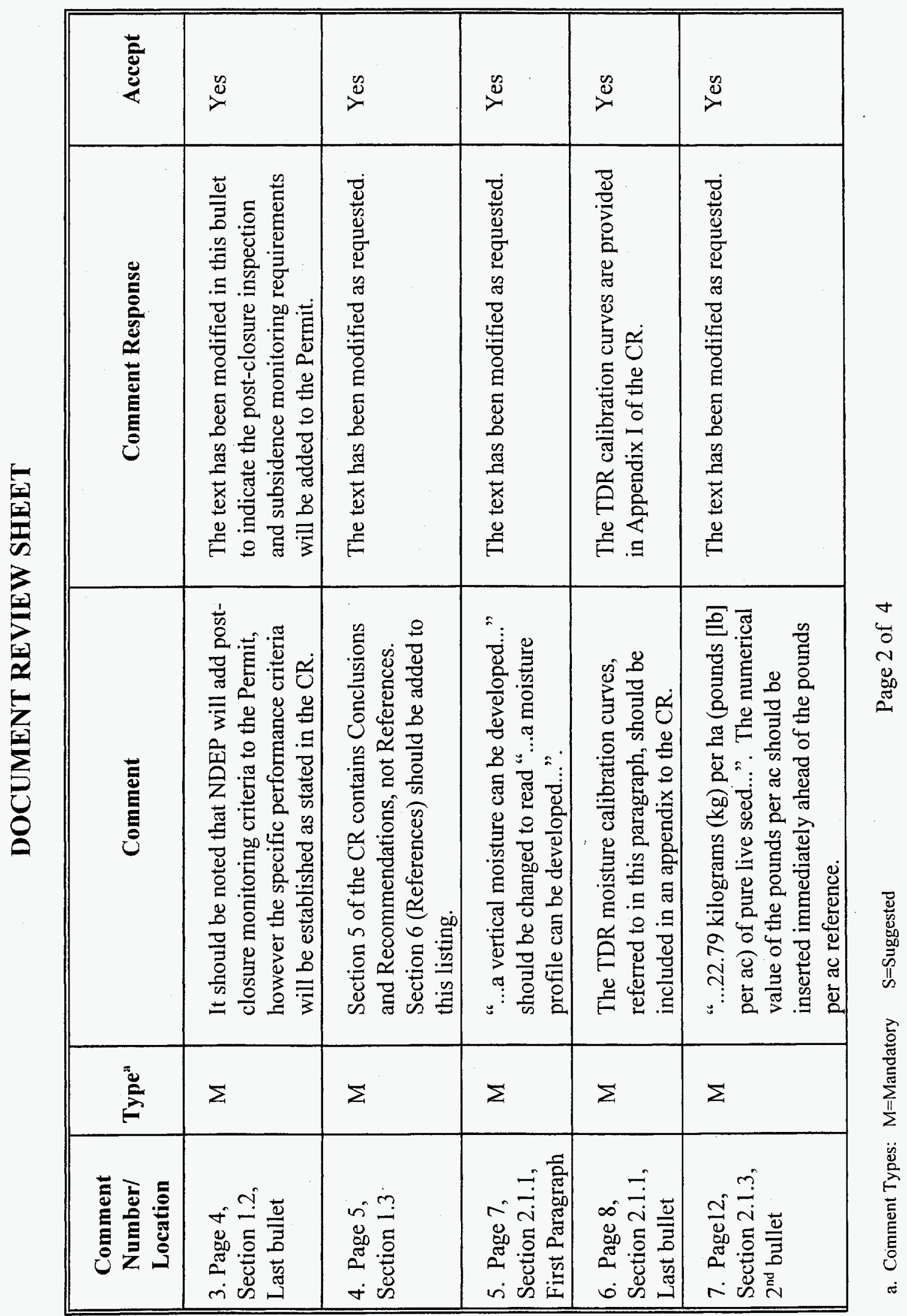




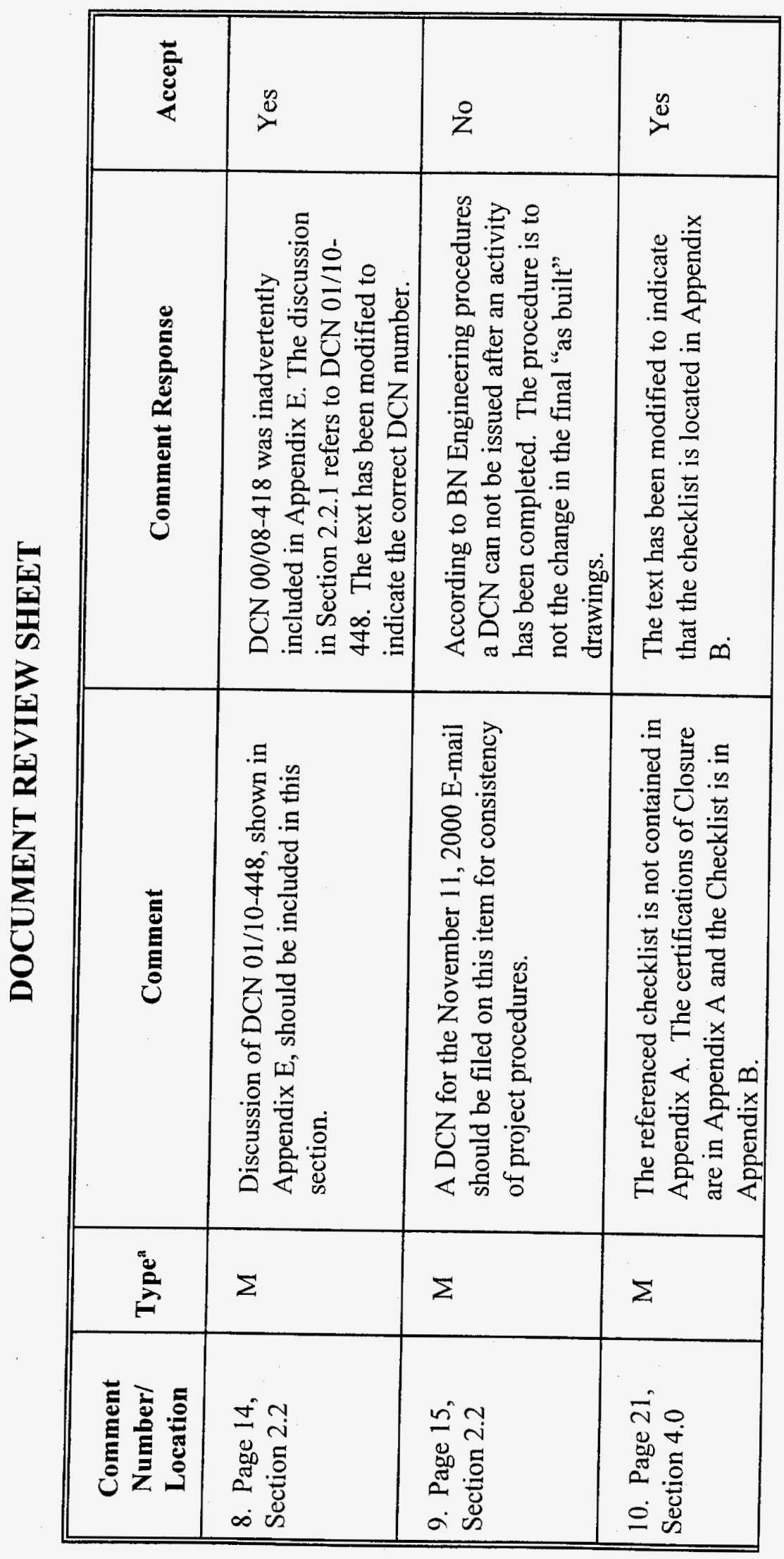

$\checkmark$
4
0
0
0
0
0

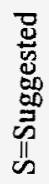

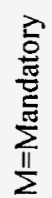

总 


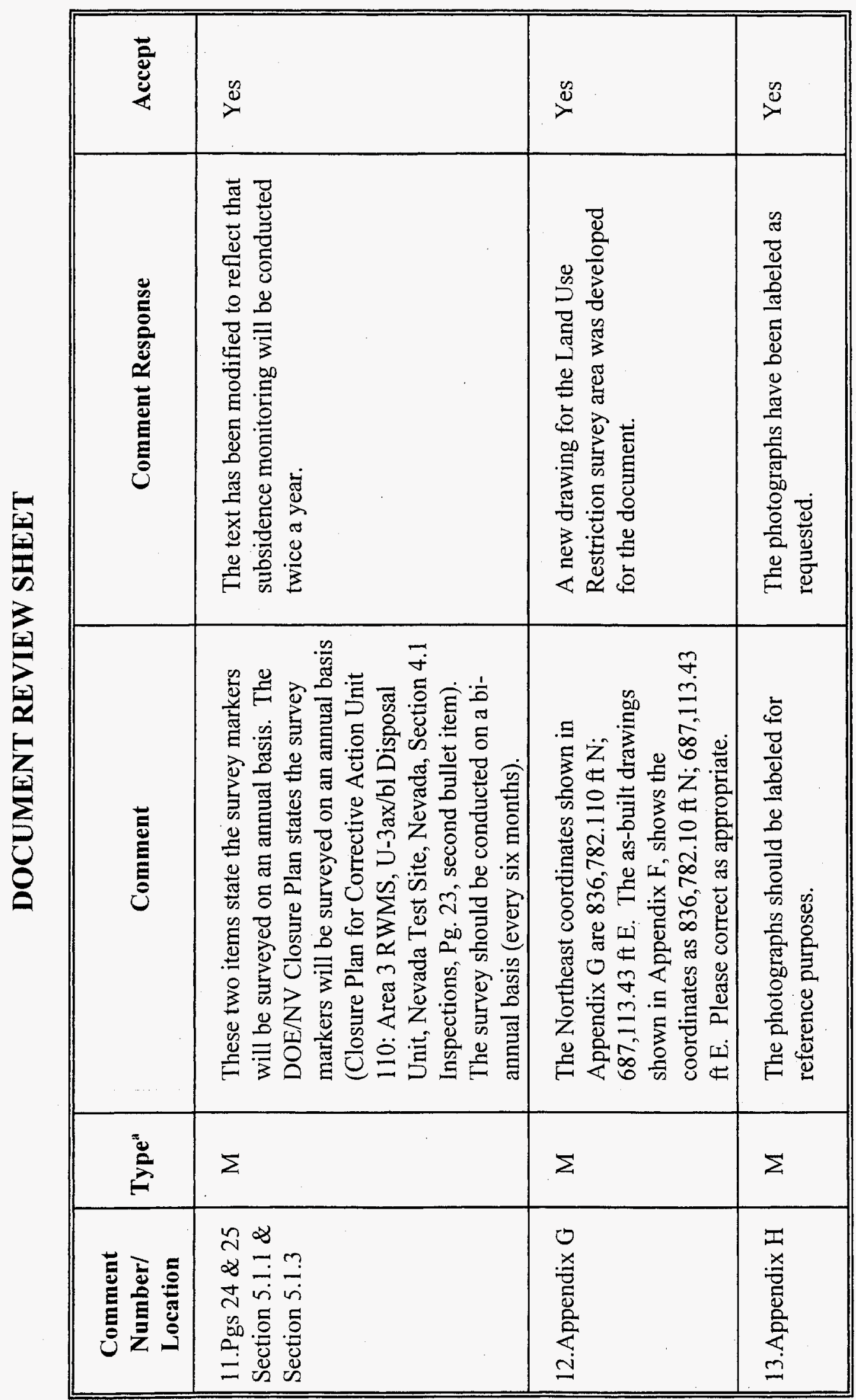

$\nabla$
4
0
0
0
0

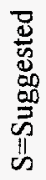

竞 


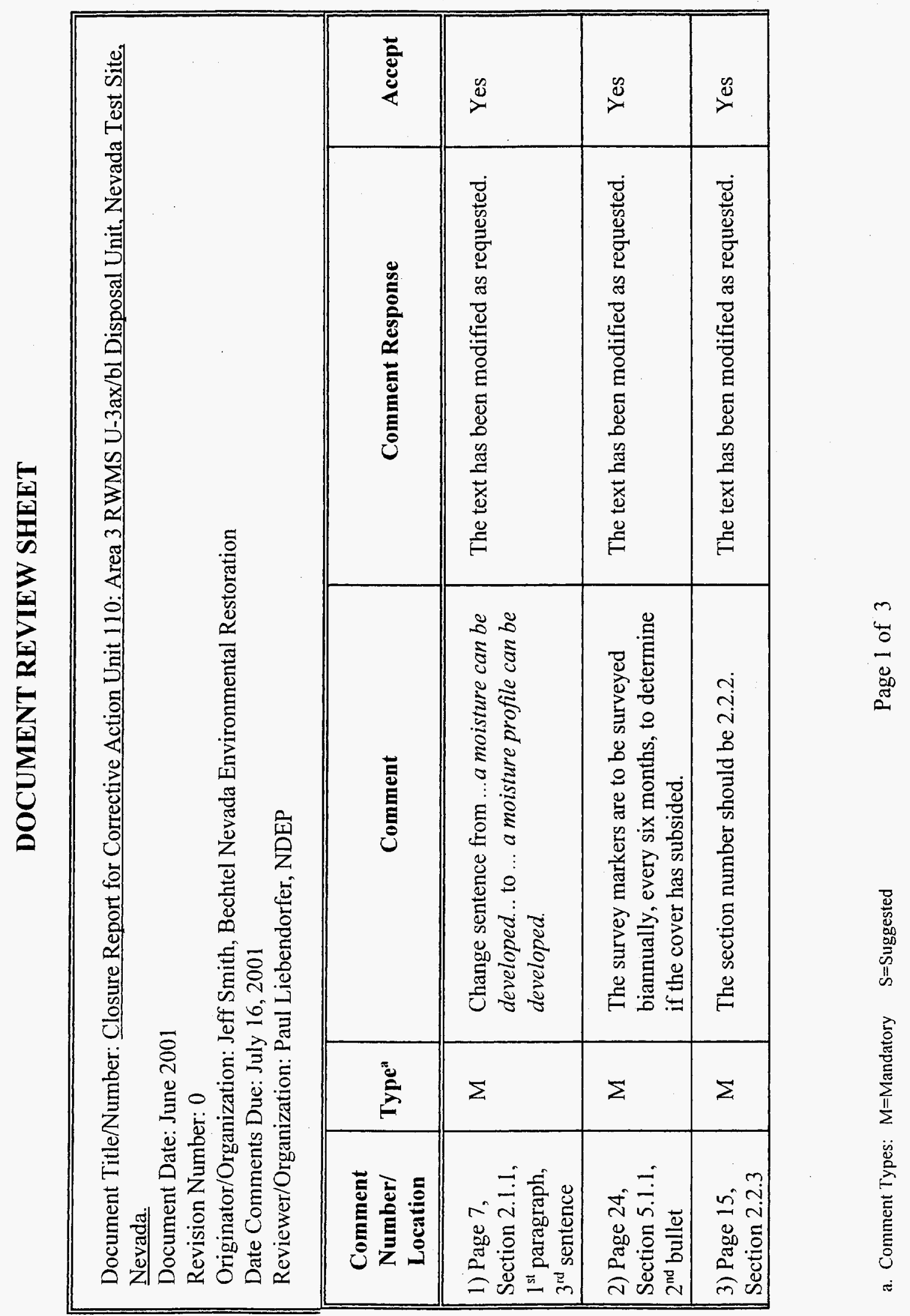




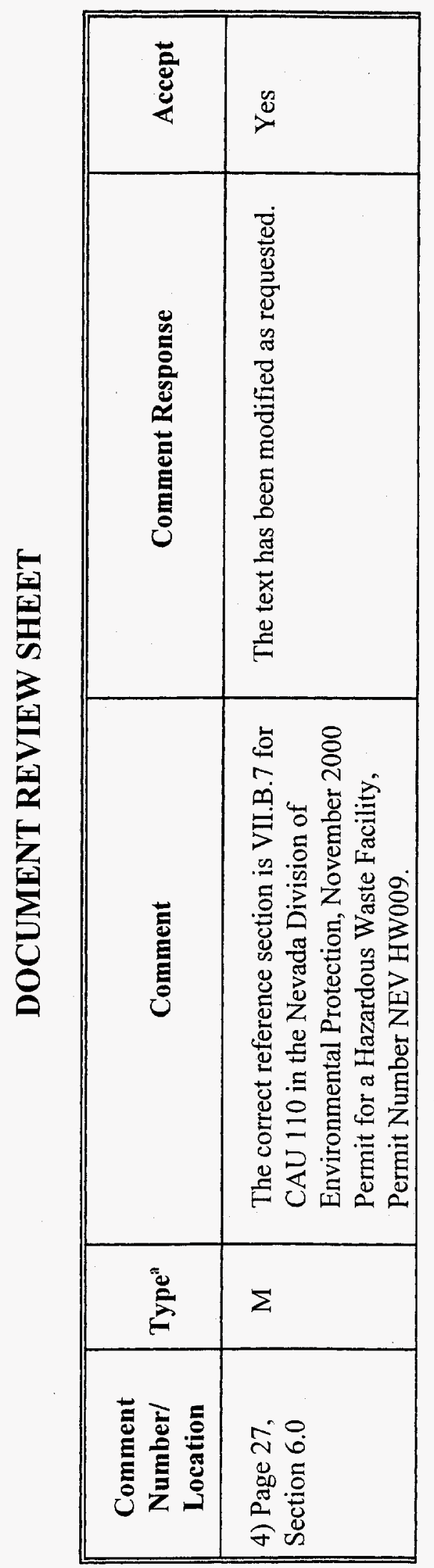

7
0
0
0
0
0
0

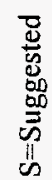

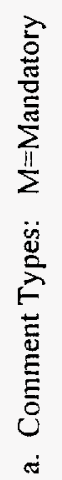




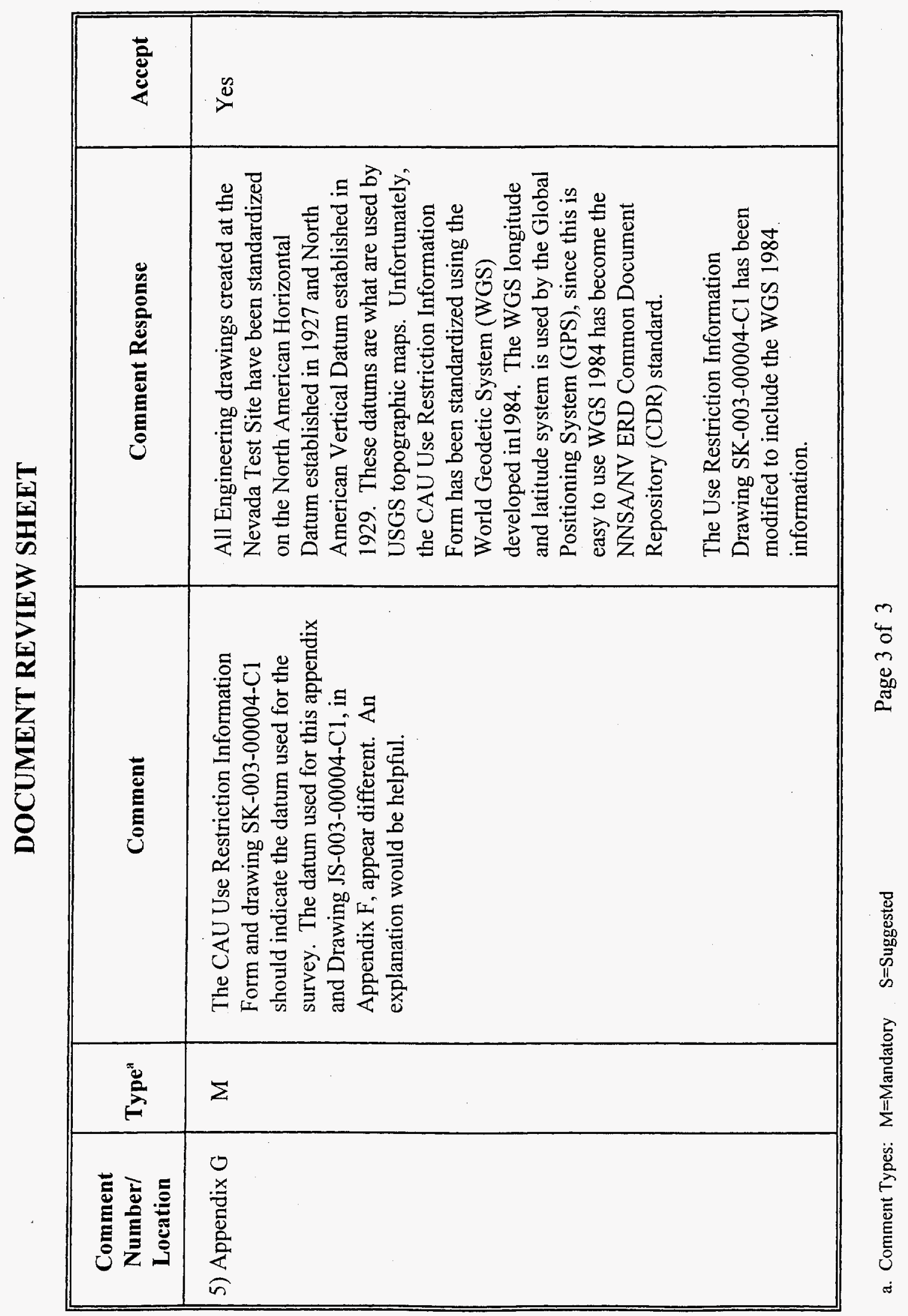


Closure Report - CAU 110

Section: Appendix J

Revision: 1

Date: August 6, 2001

a

THIS PAGE INTENTIONALLY LEFT BLANK

a

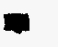

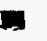

- 
Closure Report - CAL 110

Section: Distribution

Revision: 1

Date: August 6. 2001

\section{DISTRIBUTION LIST}


Closure Repon - CAL: 110

Section: Distribution

Revision: 1

Date: August 6. 2001

\section{THIS PAGE INTENTIONALLY LEFT BLANK}




\section{DISTRIBUTION LIST}

*Provide copy of initial distribution of Revision 0; remainder of list gets Revision 0 if approved without changes. The entire list receives Revision 1, if issued.

\section{Nevada Department of Environmental Protection}

Paul Liebendorfer

Bureau of Federal Facilities

Division of Environmental Protection

333 W. Nye Lane, Room 13B

Carson City, NV 89706-0866

Michael D. McKinnon

1 (Controlled)*

Bureau of Federal Facilities

Division of Environmental Protection

555 E. Washington, Suite 4300

Las Vegas, NV 89101-1049

\section{U.S. Department of Energy}

Janet Appenzeller-Wing

Environmental Restoration Division

U.S. Department of Energy,

National Nuclear Security Administration,

Nevada Operations Office

P.O. Box $98518 \mathrm{M} / \mathrm{S} 505$

Las Vegas, NV 89193-8518

Sabine Curtis

1 (Uncontrolled)*

Environmental Restoration Division

U.S. Department of Energy,

National Nuclear Security Administration,

Nevada Operations Office

P.O. Box $98518 \mathrm{M} / \mathrm{S} 505$

Las Vegas, NV 89193-8518 


\section{DISTRIBUTION LIST (Continued)}

\section{U.S. Department of Energy (continued)}

Sabrina Lawrence

1 (Controlled)*

Environmental Restoration Division

U.S. Department of Energy,

National Nuclear Security Administration,

Nevada Operations Office

P.O. Box $98518 \mathrm{M} / \mathrm{S} 505$

Las Vegas, NV 89193-8518

Public Reading Facility

1 (Controlled)

U.S. Department of Energy,

National Nuclear Security Administration,

Nevada Operations Office

P.O. Box $98521 \mathrm{M} / \mathrm{S}$ NLV040

Las Vegas, NV 89193-8521

Technical Information Resource Center

1 (Uncontrolled)

U.S. Department of Energy,

National Nuclear Security Administration,

Nevada Operations Office

P.O. Box $98521 \mathrm{M} / \mathrm{S} 505$

Las Vegas, NV 89193-8521

U.S. Department of Energy

1 (Uncontrolled)

Office of Scientific and Technical Information

175 Oak Ridge Turnpike

P.O. Box 62

Oak Ridge, TN 37831-0062 
Date: August 6. 2001

\section{DISTRIBUTION LIST (Continued)}

\section{Bechtel Nevada}

Correspondence Control

1 (Uncontrolled)*

Bechtel Nevada

P.O. Box $98521 \mathrm{M} / \mathrm{S}$ NLV008

Las Vegas, NV 89193-8521

Environmental Management Library

1 (Uncontrolled)*

Bechtel Nevada

P.O. Box 98521 M/S NLV080

Las Vegas, NV 89193-8521

Tom Fitzmaurice

1 (Uncontrolled)*

Bechtel Nevada

P.O. Box $98521 \mathrm{M} / \mathrm{S}$ NTS306

Las Vegas, NV 89193-8521

Brad Jackson

1 (Uncontrolled)*

Bechtel Nevada

P.O. Box $98521 \mathrm{M} / \mathrm{S}$ NTS306

Las Vegas, NV 89193-8521

Wayne Johnson

1 (Uncontrolled)*

Bechtel Nevada

P.O. Box $98521 \mathrm{M} / \mathrm{S}$ NTS306

Las Vegas, NV 89193-8521

Steve Nacht

1 (Uncontrolled)*

Bechtel Nevada

P.O. Box $98521 \mathrm{M} / \mathrm{S}$ NTS306

Las Vegas, NV 89193-8521 
Date: Augusı 6. 2001

\section{DISTRIBUTION LIST (Continued)}

\section{Bechtel Nevada (continued)}

Jeffery Smith

1 (Uncontrolled)*

Bechtel Nevada

P.O. Box $98521 \mathrm{M} / \mathrm{S}$ NTS306

Las Vegas, NV 89193-8521

\section{PEER Consultants}

Gary Hudak

2 (Uncontrolled)

PEER Consultants

P.O. Box $98521 \mathrm{M} / \mathrm{S}$ NLV082

Las Vegas, NV 89193-8521 